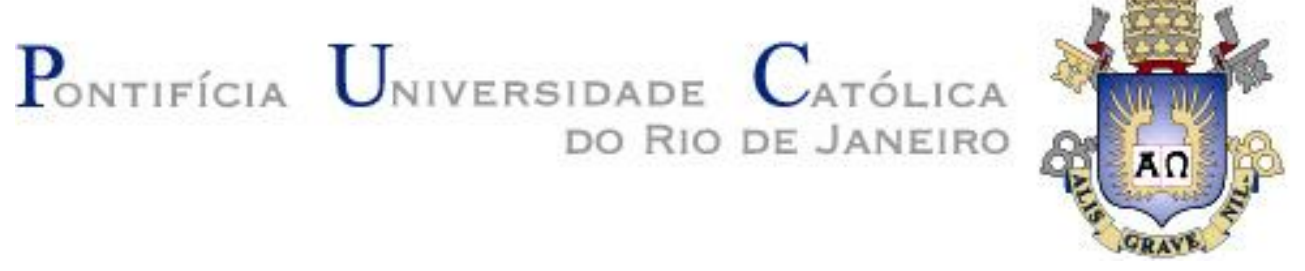

Natália de Oliveira de Paula Cidade

\title{
A DIMENSÃO ARCAICA DAS AUTOMUTILAÇÕES: Descontinuidades nos primórdios da vida
}

Tese de Doutorado

Tese apresentada como requisito parcial para obtenção do grau de Doutor pelo Programa de Pós-Graduação em Psicologia (Psicologia Clínica) da PUC-Rio.

Orientadora: Prof ${ }^{a}$. Silvia Maria Abu-Jamra Zornig 


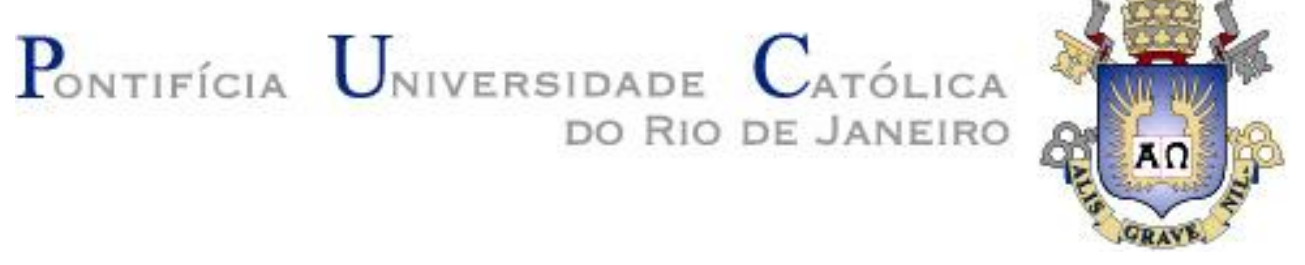

Natália de Oliveira de Paula Cidade

\begin{abstract}
A dimensão arcaica das automutilações: descontinuidades nos primórdios da vida

Tese apresentada como requisito parcial para obtenção do grau de Doutor pelo Programa de Pós-Graduação em Psicologia (Psicologia Clínica) da PUC-Rio. Aprovada pela Comissão Examinadora abaixo.
\end{abstract}

Profa. Silvia Maria Abu-Jamra Zornig Orientadora Departamento de Psicologia - PUC-Rio

Profa. Terezinha Féres-Carneiro Departamento de Psicologia - PUC-Rio

Profa. Marta Rezende Cardoso Instituto de Psicologia - UFRJ

Prof. Alberto Leonel Konicheckis Université Paris Descartes - Paris V

Profa. Regina Maria Orth de Aragão Associação Brasileira de Estudos sobre o Bebê - ABEBÊ

Rio de Janeiro, 06 de março de 2020 
Todos os direitos reservados. É proibida a reprodução total ou parcial do trabalho sem autorização da universidade, da autora e da orientadora.

\section{Natália de Oliveira de Paula Cidade}

Graduou-se em Psicologia no ano de 2011 pela Universidade Federal do Rio de Janeiro - UFRJ. Especialista em Clínica Psicanalítica pelo Instituto de Psiquiatria da Universidade Federal do Rio de Janeiro - IPUB/UFRJ. Mestre em Psicologia Clínica pela Pontifícia Universidade Católica do Rio de Janeiro - PUC-Rio. Psicóloga clínica da Universidade do Estado do Rio de Janeiro UERJ. Dedica-se atualmente à área clínica e pesquisas acadêmicas no campo da psicologia/psicanálise.

Ficha Catalográfica

Cidade, Natália de Oliveira de Paula

A dimensão arcaica das automutilações : descontinuidades nos primórdios da vida / Natália de Oliveira de Paula Cidade; orientadora: Silvia Maria Abu-Jamra Zornig. - 2020.

149 f.; $30 \mathrm{~cm}$

Tese (doutorado) - Pontifícia Universidade Católica do Rio de Janeiro, Departamento de Psicologia, 2020.

Inclui bibliografia.

1. Psicologia - Teses. 2. Automutilação. 3. Constituição psíquica. 4. Arcaico. 5. Intersubjetividade. 6. Clínica psicanalítica. I. Zornig, Silvia Maria Abu-Jamra. II. Pontifícia Universidade Católica do Rio de Janeiro. Departamento de Psicologia. III. Título. 


\section{Agradecimentos}

À minha família, por todo apoio e incentivo à minha paixão de pesquisar. Por nutrirem e fomentarem minhas curiosidades pelo mundo, desde tempos imemoriais.

À Ana Carolina Vasconcellos, por atravessar essa jornada comigo. Por todo seu suporte, carinho e paciência ao longo do caminho.

Ao André Luiz Vale, por me ver com olhos de encorajamento e potência. Pelo cuidado na leitura e revisão desse trabalho. Por ser parte da família que escolhi em vida.

À Paula Melgaço, Leonardo Câmara e Suéllen Buchaúl, por acreditarem na minha capacidade de criar. Por me darem força e estarem sempre perto, mesmo quando a distância aumentou.

A todos os meus amigos, por tornarem a vida mais fácil nos percursos mais difíceis.

À Silvia Zornig, por seguir me apresentando a novos mundos teóricos. Pela parceria encontrada, pelo incentivo às minhas ideias de pesquisa e pelas oportunidades de crescimento, que mudaram os rumos da minha vida profissional.

Ao Alberto Konicheckis e François Marty, que generosamente me receberam em suas equipes de trabalho na França (Paris V) e compartilharam comigo um pouco de suas vastas experiências teórico-clínicas. Serei eternamente grata por estas trocas.

À Marie Rose Moro e Alice Rizzi, que gentilmente me receberam e me acompanharam durante um período de estágio na Maison de Solenn. 
À equipe de trabalho da pós-graduação, que me fortaleceu para encarar os desafios.

À Angela Perricone Pastura e Mathieu Parraton, pelo ensino e aprimoramento da língua francesa, o que me permitiu alcançar novos voos e conteúdos.

À PUC-Rio, pelos auxílios concedidos, sem os quais este trabalho não poderia ter sido realizado.

E, finalmente, aos pacientes que confiaram suas jornadas a mim, permitindo que eu os acompanhasse nessa aventura que é a vida.

O presente trabalho foi realizado com apoio da Coordenação de Aperfeiçoamento de Pessoal de Nível Superior - Brasil (CAPES) - Código de financiamento 001. 


\section{Resumo}

Cidade, Natália de Oliveira de Paula; Zornig, Silvia Maria Abu-Jamra (Orientadora). A dimensão arcaica das automutilações: descontinuidades nos primórdios da vida. Rio de Janeiro, 2020. 149p. Tese de Doutorado - Departamento de Psicologia, Pontifícia Universidade Católica do Rio de Janeiro.

A finalidade desta tese é a de refletir acerca da dimensão arcaica das automutilações e suas repercussões na clínica psicanalítica a partir do estudo da constituição psíquica e dos processos de diferenciação eu/não-eu, próprios ao início da vida. Trata-se de um fenômeno complexo composto por uma série de condutas diferenciadas que tem em comum infligir danos à própria pele, trazendo o corpo para a frente da cena. $\mathrm{O}$ ataque ao corpo realizado nos atos automutilatórios aponta para um sofrimento que não pode ser colocado em palavras e através do qual o sujeito encontra outras vias de expressão e de descarga daquilo que o faz sofrer, denunciando conteúdos e vivências que ultrapassam o universo das representações psíquicas e da linguagem verbal. Em nossa análise, priorizamos nos aprofundar nos processos de constituição subjetiva, chamando atenção para sua dimensão arcaica, que diz respeito a problemáticas narcísicas do início da vida, de construção do eu-corporal, dos primeiros encontros intersubjetivos e dos processos de diferenciação que marcam os limites entre sujeito e objeto. Nossa hipótese se constrói em torno do entendimento de que, quando os primórdios da vida são marcados majoritariamente por desencontros e desarmonias, haverá consequências severas nos processos de subjetivação do bebê, refletindo na problemática da automutilação. Sustentamos que o recurso ao corpo e ao sensorial na automutilação aponta para uma tentativa de contenção do eu em momentos nos quais o sujeito sente que pode haver o risco da perda da integridade narcísica. Nessa direção, as automutilações representam uma via atual através da qual experiências precoces, da ordem do arcaico, se apresentariam. A dimensão arcaica proposta na tese tem como referência elementos dos primórdios sensoriais que ultrapassam a memória dos acontecimentos cronológicos, permanecendo ativos no presente e no atual, nas formas de se relacionar com os outros sujeitos. 


\section{Palavras-chave}

Automutilação; constituição psíquica; arcaico; intersubjetividade; clínica psicanalítica. 


\section{Résumé}

Cidade, Natália de Oliveira de Paula; Zornig, Silvia Maria Abu-Jamra (Directrice de thèse). La dimension archaïque des automutilations: discontinuités à l'aube de la vie. Rio de Janeiro, 2020. 149p. Tese de Doutorado - Departamento de Psicologia, Pontifícia Universidade Católica do Rio de Janeiro.

L'objectif de cette thèse est de réfléchir à la dimension archaïque des automutilations et ses répercussions sur la clinique psychanalytique ayant comme point de départ la constitution psychique et les processus de différenciation moi/non moi, propres au début de la vie. Les automutilations constituent un phénomène complexe composé d'une série de conduites différenciées, qui ont en commun le fait d'infliger du mal à sa propre peau, soulignant l'importance du corps. L'attaque du corps effectuée dans les actes d'automutilation pointe une souffrance qui ne peut pas être mise en mots et à travers laquelle le sujet trouve d'autres voies d'expression et de décharge de ce qui le fait souffrir. Ces actes dénoncent des contenus et des expériences qui dépassent les représentations psychiques et qui vont au-delà du langage verbal. Dans notre analyse, nous priorisons l'approfondissement des processus de constitution subjectifs, attirant l'attention sur sa dimension archaïque. Cette dimension concerne les problématiques narcissiques du début de la vie, la construction du moi-corps, les premières rencontres intersubjectives et les processus de différenciation qui marquent les limites entre sujet et objet. Notre hypothèse se construit autour de la compréhension selon laquelle, lorsque les débuts de la vie sont marqués principalement par des discontinuités et des désharmonies, il y aura de graves conséquences sur les processus de subjectivation du bébé, ce que reflète la problématique de l'automutilation. Nous soutenons que le recours au corps et au sensoriel dans l'automutilation indique une tentative de contenir le moi dans les moments où le sujet sent qu'il peut y avoir un risque de perte d'intégrité narcissique. En ce sens, l'automutilation représente une voie actuelle à travers laquelle des expériences précoces, du champ de l'archaïque, se présenteraient. La dimension archaïque proposée dans la thèse a comme référence des éléments des débuts sensoriels, qui dépassent la mémoire des 
événements chronologiques et qui restent bel et bien actifs dans le présent et dans l'actuel, dans les relations avec d'autres sujets.

\section{Mots-clés}

Automutilation; constituition psychique; l'archaïque; l'intersubjectivité; clinique psychanalytique. 


\section{Sumário}

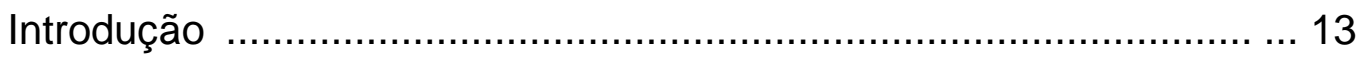

1 Automutilação: definindo o conceito .......................................... 18

1.1 Descrições do fenômeno ........................................................ 19

1.2 Breve passeio histórico pelas classificações existentes ................ 23

1.3 Síndrome $x$ sintoma: o estatuto das automutilações ..................... 31

1.4 Aproximações e diferenças entre a automutilação e o comportamento suicidário ..................................................... 37

2 A problemática do corpo na automutilação ................................ 44

2.1 Automutilação na clínica psicanalítica: a prevalência da

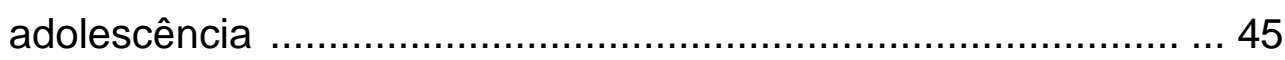

2.20 corpo e o pré-verbal na automutilação .................................... 53

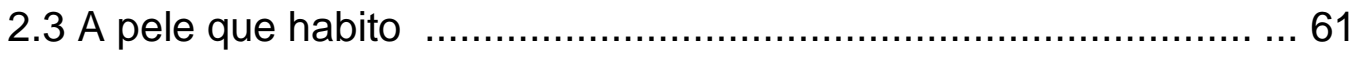

3 Automutilação e constituição psíquica: descontinuidades nos

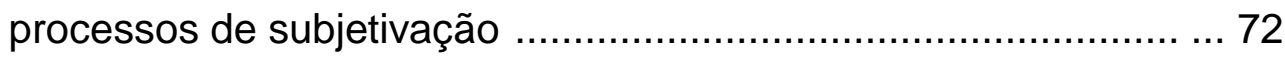

3.1 Automutilação e a questão da separação: ecos de uma história primeva .................................................................. 73

3.2 Intersubjetividade e o sentimento de continuidade de

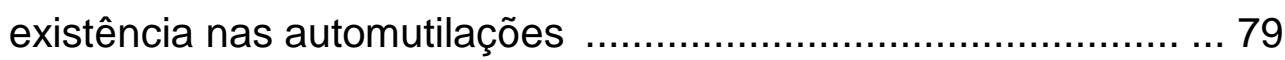

3.3 Rumo aos processos de diferenciação …….............................. 88

3.4 Descontinuidades nas origens da automutilação ......................... 95

4 A dimensão do arcaico e suas repercussões para a clínica da

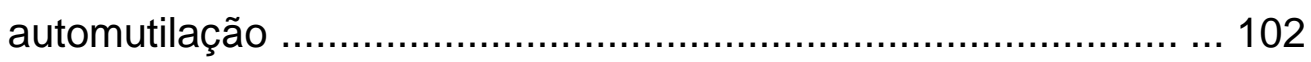

4.1 Ressonâncias do arcaico na clínica da automutilação .................. 103

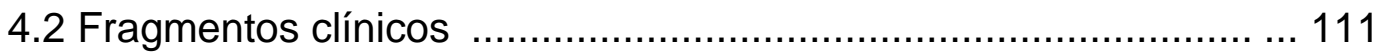

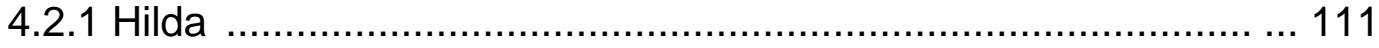

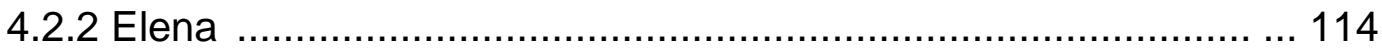


4.2.3 Rita

4.3 A dinâmica do "mostrado/escondido" e a importância do olhar como possibilidade de integração 122

5 Considerações finais 128

6 Referências bibliográficas 139 
Oh, pedaço de mim Oh, metade afastada de mim Leva o teu olhar Que a saudade é o pior tormento É pior do que o esquecimento É pior do que se entrevar

Oh, pedaço de mim Oh, metade exilada de mim Leva os teus sinais Que a saudade dói como um barco Que aos poucos descreve um arco E evita atracar no cais

Oh, pedaço de mim Oh, metade arrancada de mim Leva o vulto teu Que a saudade é o revés de um parto

A saudade é arrumar o quarto

Do filho que já morreu

Oh, pedaço de mim Oh, metade amputada de mim

Leva o que há de ti Que a saudade dói latejada É assim como uma fisgada No membro que já perdi

Oh, pedaço de mim Oh, metade adorada de mim

Lava os olhos meus Que a saudade é o pior castigo E eu não quero levar comigo A mortalha do amor Adeus

Chico Buarque de Holanda 


\section{Introdução}

Lembro que, quando tudo começou, era escuro. E hoje, depois de todos esses anos de labirinto, todos esses anos em que avanço pela neblina empunhando a caneta adiante do meu peito, percebo que o escuro era uma ausência. Uma ausência de palavras. Essa escuridão é minha pré-história. Eu antes da história, eu antes das palavras. Eu

caos.

Eliane Brum

A automutilação é um fenômeno que não pertence a um único campo de estudo, conjugando o interesse de diversas áreas, como a Psicanálise, a Psicologia e a Psiquiatria; mas também a Antropologia e a Sociologia. Ela denomina o ato de ferir o próprio corpo em diferentes contextos e por diferentes razões. Encontramos descrições dos fenômenos de automutilação na literatura desde o século VI A.C., com os cultos e rituais de antigas civilizações. Também podemos observá-los nos ritos de passagens de povos primitivos e sociedades tribais, de forma que sabemos que este não é um fenômeno novo ou próprio de nossa sociedade ocidental. O tipo de automutilação encontrado nos ritos de passagem está circunscrito por significações prévias, que variam de acordo com o tempo, a região e a cultura nos quais os sujeitos encontram-se inseridos - seja uma posição dentro da sociedade, memória de eventos importantes (tais como guerra, casamento, luto) ou apenas um pertencimento estético que demarque suas origens e filiações.

Diferentemente deste tipo de automutilação, que já possui aceitação social e conteúdo designado a priori, a sociedade ocidental vem se deparando com atos automutilatórios que não reenviam necessariamente a nenhum sentido prévio nem designam pertencimento a clãs ou a tribos sociais. Nesses casos, encontramos sujeitos em estados extremos de vulnerabilidade psíquica, praticando atos de automutilação com o intuito de se livrar de uma carga de sofrimento para a qual não conseguem dar outro destino. Na direção oposta aos tipos de prática que levam em conta o pertencimento grupal ou os ritos de passagem, essas automutilações apontam para algum grau de sofrimento psíquico.

Os registros desta forma mais recente de automutilação datam do século XIX, mas verificamos um aumento de estudos sobre o tema desde a década de 1960, com aumento ainda maior do número de casos clínicos em unidades de 
saúde e consultórios particulares nas duas últimas décadas. Desde os meados da década de 1970, tem havido um aumento significativo das condutas de automutilação, em especial entre os adolescentes. Alguns estudos realizados em diferentes países - dentre os quais destacamos a França, os Estados Unidos e o Brasil - apontam para este acréscimo preocupante no número de casos de automutilação e voltam seus recursos de pesquisa para tentar circunscrever e compreender melhor essa questão.

Apesar disso, os estudos existentes ainda são escassos e não homogêneos, culminando em longas discussões acerca do que seria a automutilação e qual termo designa e descreve quais comportamentos. Nessa direção, a temática da automutilação começa a aparecer com mais frequência nas escolas, nos postos de saúde e nos consultórios particulares, tornando-se cada vez mais urgente o aprofundamento e a discussão sobre o assunto.

A automutilação não possui uma homogeneidade como conceito, nem em relação à nomenclatura, nem no que se refere à compreensão do fenômeno. A maioria dos autores apresenta ideias e entendimentos variados sobre o assunto, com algumas coincidências. Importante ressaltar que, nesta área, existe a ideia de que tais condutas podem ser encontradas, em sua maioria, relacionadas a quadros psicopatológicos mais graves, como o autismo e a psicose, ou ao momento de transições e mudanças advindas da adolescência.

Grande parte do material encontrado sobre a temática das automutilações diz respeito a uma convergência com o momento da adolescência, uma vez que este fenômeno tem crescido bastante entre os jovens. Todavia, o interesse deste trabalho se volta para momentos anteriores da constituição psíquica e para a forma através da qual as primeiras relações com nossos objetos primordiais nos marcam na pele. Nesse sentido, apesar da indicada prevalência da automutilação no período da adolescência, gostaríamos de propor uma reflexão acerca da dimensão arcaica que se encontra presente nas automutilações, independentemente da faixa etária ou do quadro psicopatológico destes sujeitos.

O interesse pela temática das automutilações surgiu a partir do meu percurso teórico clínico, esmiuçando alguns questionamentos iniciados no Mestrado em Psicologia Clínica na Pontifícia Universidade Católica do Rio de Janeiro (PUC-Rio). A partir dos conhecimentos adquiridos no aprofundamento sobre o funcionamento e a constituição psíquica de casos de sofrimentos 
narcísico-identitários e suas repercussões para a técnica e a clínica psicanalítica, encontrei a noção de polifonias e a ideia de que era possível (e necessário) ampliar a escuta do analista para além do campo do verbal. Esta discussão me abriu portas para que eu pudesse ouvir outros elementos no setting, me permitindo reunir e ressignificar todo o material clínico vivido durante um curso de especialização com pacientes graves internados, assim como casos atendidos no meu consultório particular.

Minha experiência clínica com pacientes graves começou a partir do curso de especialização em Clínica Psicanalítica no Instituto de Psiquiatria da Universidade Federal do Rio de Janeiro (IPUB/UFRJ). Somado aos atendimentos dos pacientes internados, o curso contava com a imersão ambulatorial em uma riqueza de casos, vivências e experiências absolutamente essenciais para minha formação clínica. Neste período, acompanhei uma série de pacientes que apresentavam comportamentos automutilatórios variados, fato este que já me intrigava técnica e teoricamente. Em conjunto com o trabalho no hospital psiquiátrico, minha clínica particular começou a receber ecos deste meu novo interesse teórico e comecei a receber mais casos de automutilação. Foi a partir de dificuldades encontradas na prática clínica com estes pacientes que as questões teóricas desenvolvidas ao longo deste texto começaram a ser formuladas e aprofundadas.

Complementando a experiência no campo da automutilação, destaco o período de Doutorado Sanduíche na Universidade Paris V e o estágio realizado na Maison de Solenn, também em Paris, unidade de saúde de referência especializada no atendimento de adolescentes. As produções científicas e os trabalhos sobre automutilação encontram-se em pleno desenvolvimento na França desde o início dos anos 2000. A oportunidade de ter acesso a diversos materiais in loco e de participar de congressos e seminários sobre o tema foi extremamente enriquecedora. Assim como a participação nos seminários de pesquisa dos professores Alberto Konicheckis e François Marty neste período, realizando trocas acerca desta temática, e a possibilidade de estar em contato com adolescentes internados na unidade hospitalar da Maison de Solenn, foram pontos transformadores para a realização do presente trabalho.

Provindo de questões levantadas na prática, inicio este percurso teórico apoiada em algumas reflexões. No primeiro capítulo, definiremos o conceito de 
automutilação que será adotado por nós no presente trabalho, complexificando o campo de estudos sobre o tema. Apresentaremos uma série de definições e compreensões distintas do fenômeno, com a intenção de circunscrever teoricamente nosso objeto de estudo. Buscaremos ainda tecer um diálogo entre a Psicanálise e a Psiquiatria, uma vez que o campo da Psiquiatria define e estuda o fenômeno desde o século XIX, tendo mostrado sua importância na tentativa de compreensão e de tratamento desta problemática. Apresentaremos ainda as principais questões que surgem no campo das automutilações, de forma a destrinchar o campo a ser estudado. Para tanto, tomaremos como base os principais autores que são referência nos trabalhos sobre automutilação: Armando Favazza, Karl Menninger, Richard Rosenthal, Mansell Pattison, Joel Kahan, Ludovic Gicquel e Maurice Corcos.

No segundo capítulo, destacaremos a importância do corpo na problemática das automutilações. A partir da investigação da prevalência deste fenômeno no período da adolescência, ressaltaremos o corpo, que toma a frente da cena, em suas diferentes dimensões. Se, por um lado, a adolescência, e o corpo, comportam um nível de elementos audíveis a partir do campo do verbal e da representação, por outro lado, o recurso ao corpo encontrado nos atos automutilatórios também nos dá notícias de elementos da ordem do pré-verbal, cuja inscrição se dá no próprio corpo. Nessa direção, vamos aprofundar a investigação da pele como órgão escolhido para o ataque nas condutas automutilatórias, levando em consideração sua importância nos processos de constituição psíquica e de subjetivação. Para a construção deste capítulo, tomaremos como base os escritos sobre adolescência e automutilação de Fanny Dargent, Catherine Matha, Ludovic Gicquel e Maurice Corcos, dentre outros. Sobre as temáticas do corpo e da pele, buscaremos suporte, para além das contribuições freudianas, nos escritos de René Roussillon, Bernard Golse, Didier Anzieu e Joyce McDougall.

No terceiro capítulo, adentraremos nos primórdios da subjetivação, com o intuito de melhor investigar alguns processos que se inauguram no início da vida psíquica e que nos auxiliam a compreender a problemática dos sujeitos que se automutilam. Tendo como base as operações de diferenciação, que delimitam as fronteiras iniciais entre sujeito e objeto, refletiremos acerca da formação do primeiro par intersubjetivo e da importância dos domínios da sensorialidade e do 
ritmo como mediadores do mundo para o bebê, enquanto o objeto não pode ser sentido como totalmente diferenciado do sujeito. A apreensão desses primeiros contatos com o mundo através desses elementos, de forma harmônica e em sintonia, será de extrema importância para a composição do par mãe-bebê, encontro fundamental para a formação da subjetividade. Quando estes primeiros encontros são marcados majoritariamente por desencontros e desarmonias, haverá consequências severas nos processos de subjetivação do bebê, que poderão refletir na problemática da automutilação. Para compor as bases teóricas deste capítulo, utilizaremos como principais autores Alberto Konicheckis, Victor Guerra, Frances Tustin e Geneviève Haag.

No quarto capítulo, ressaltaremos a dimensão arcaica da automutilação e suas repercussões clínicas, levando em consideração os elementos dos primórdios sensoriais, destacando que estes elementos não se encontram perdidos em uma memória "passada" dos acontecimentos cronológicos, mas sim ativos no presente e no atual, nas formas de se relacionar com os outros sujeitos. Nos quadros de automutilação, essa dimensão arcaica se faz presente especialmente na clínica, demandando do analista uma disponibilidade polifônica complementar ao campo do verbal, permitindo que ele "escute" também elementos que fazem parte de uma comunicação pré-verbal e afetiva. Com o intuito de melhor exemplificar esta dimensão arcaica, apresentaremos três fragmentos de casos atendidos pela autora, entrelaçando as discussões do presente trabalho com a prática clínica. Para dar suporte às discussões propostas, contaremos com o auxílio teórico de Albert Ciccone, Anne Brun, Donald Winnicott e Geneviève Haag. 


\title{
1 \\ Automutilação: definindo o conceito
}

\author{
- E de que serve, então, eles terem nomes, \\ se não atendem por esses nomes? - Estranhou o Mosquito. \\ - Para eles não serve de nada-Alice explicou. \\ - Mas é útil para as pessoas que dão os nomes, eu acho. \\ Se não, por que dar nome às coisas? \\ Lewis Carroll
}

Encontramos descrições dos fenômenos de automutilação na literatura desde o século VI A.C., com os cultos e rituais de antigas civilizações. Também podemos observá-los nos ritos de passagem de povos primitivos e sociedades tribais, de forma que sabemos que este não é um fenômeno novo ou próprio de nossa sociedade ocidental. Contudo, fizemos uma escolha metodológica no presente trabalho de não nos referirmos a estes tipos de prática que levam em conta o grupo ou ritos de passagem, mas sim às automutilações que podem apontar para algum grau de sofrimento psíquico.

Dentro deste recorte, os estudos sobre o tema começaram no século XIX, dentro do campo da Psiquiatria, ganhando destaque na clínica atual, na qual o fenômeno encontra-se cada vez mais presente. Nos últimos anos, a Psicanálise passou a se ocupar de forma mais direta desta problemática, trazendo contribuições importantes ao entendimento deste campo. Encontramos o termo "automutilação" sendo utilizado de forma ampla, podendo designar condutas bastante abrangentes. Entretanto, ao nos debruçarmos sobre as definições da automutilação, nos damos conta de que o fenômeno é muito mais complexo do que é comumente observado na literatura sobre o tema.

Sendo assim, tivemos como objetivo no presente capítulo trazer à luz a complexidade dos estudos sobre o tema, partindo das diferentes definições existentes na literatura sobre o fenômeno, inicialmente circunscritas ao campo da Psiquiatria e posteriormente apropriadas pela Psicanálise, e suas interlocuções com temas correlatos. Desejamos sublinhar que a automutilação não se limita aos cortes superficiais na pele, como ela é frequentemente representada, mas diz respeito a uma série de condutas diferenciadas que tem em comum os danos infligidos à própria pele. 


\section{1 \\ Descrições do fenômeno}

No campo da Psiquiatria, a definição mais utilizada de automutilação é a de Feldman (1988), que se caracteriza por um dano autoinfligido intencionalmente a uma parte de seu próprio corpo, sem a intenção consciente de morte. No mesmo ano, Walsh e Rosen (1988) publicam o livro Self-mutilations: Theory, research and treatment, no qual sugerem uma definição bastante parecida, porém acrescentam ainda as dimensões da não letalidade e da inadequação social desta prática.

Atualmente, a automutilação é considerada como um subgrupo dentro de um grupo maior denominado de comportamentos autoagressivos. Esta divisão foi realizada a partir de algumas pesquisas na área da Psiquiatria, em especial as de Ross e McKay (1979) e as de Pattison e Kahan (1983). Ross e McKay (1979) repertoriaram mais de trinta comportamentos autoagressivos, dentre os quais localizam a automutilação como uma autoagressão direta, na qual o sujeito faz mal para si mesmo de forma deliberada. Pattison e Kahan (1983) classificam os comportamentos autodestrutivos como atos que seguem uma continuidade de espectro, indo desde as automutilações até o suicídio (o mais extremo dos comportamentos autodestrutivos, segundo os autores).

Desde meados da década de 1970, tem havido um aumento significativo das condutas de automutilação, em especial entre os adolescentes. Alguns estudos realizados em diferentes países - dentre os quais destacamos a França, os Estados Unidos e o Brasil - apontam para este acréscimo preocupante e voltam seus recursos de pesquisa para tentar circunscrever e compreender melhor essa questão (Favazza, 1987/2011; Corcos \& Richard, 2006; Giusti, 2013). Apesar disso, os estudos existentes ainda são escassos e não homogêneos, culminando em longas discussões acerca do que seria a automutilação e qual termo designaria quais comportamentos.

No âmbito da Psiquiatria, encontramos uma gama variada de termos para se referir a esses comportamentos que visam causar um dano direto ao organismo e são realizados pela própria pessoa: 1) Automutilação - Self-mutilation (Menninger, 1938; Ross \& McKay, 1979; Favazza, 1987/2011; Feldman, 1988; 
Walsh \& Rosen, 1988; Suyemoto, 1998); 2) Autoagressão - Self-harm (Pattison \& Kahan, 1983); 3) Autolesão - Self-injury (Knock, 2010).

No âmbito da Psicanálise, também encontramos diversos termos para se referir ao fenômeno, alguns em comum com a Psiquiatria. Dentre eles, destacamos os seguintes: 1) Automutilação - Automutilation (Scaramozzino, 2004; Corcos \& Richard, 2006; Gicquel \& Corcos, 2011; Garel, 2008); 2) Autoagressão - Auto-agression (Brassine \& Lefebvre, 2007); 3) Feridas autoinfligidas - Blessures auto-infligées (Perret-Catipovic, 2005); 4) Violências cutâneas autoinfligidas - Violences cutanées auto-infligées (Pommereau, 2006a; 2006b).

Apesar da diversidade de termos e das dificuldades encontradas em cada um deles, optamos por manter a escolha do termo automutilação, levando em consideração que ele aparece descrito na maior parte dos artigos aqui utilizados. Catherine Matha (2010) aponta que os próprios sujeitos que experienciam a vivência de lesar o corpo preferem o termo automutilação. A autora divide a palavra em dois: os sujeitos localizam no termo auto uma tentativa de recuperar a atividade diante de alguma vivência anterior à qual foram submetidos passivamente. Dessa forma, são eles que fazem o corpo sofrer, acreditando que obterão algum domínio, mesmo que precário, diante de uma dor psíquica descomunal. E em relação ao termo mutilação, a autora sublinha que ele contém a violência daquilo que é experimentado e que seria justamente o caráter violento do ato que torna essa prática socialmente inaceitável.

Partindo do enlace entre teoria e clínica, optamos pelo termo automutilação na esperança de ampliar a compreensão de um fenômeno encontrado de forma tão diversificada e singular. Contudo, podemos nos perguntar no que consistiria, afinal, a "automutilação"? A que práticas estamos nos referindo ao usarmos este termo? Que tipos de conduta ele engloba e o que levaria algum sujeito a ferir a própria pele?

O presente trabalho se apoia em uma escuta clínica que comporta diferentes casos e situações subjetivas, de forma que alguns pacientes não se encaixam em nenhuma das definições mais restritivas do fenômeno. Em geral, eles trazem uma gama bastante ampla de agressões direcionadas ao corpo, que podem ser encontradas de forma isolada ou complementar (uma ou mais práticas 
distintas), contendo uma dimensão de ataque à própria pele. Este ato provoca uma laceração, assim como uma ruptura e descontinuidade do tecido epitelial.

Explicitando dois termos citados acima, podemos dizer que, tanto a autolesão quanto a autoagressão seriam campos mais amplos, de forma que outros comportamentos destrutivos voltados para a própria pessoa também se encontram presentes nestes, tais como abuso de substâncias, interrupção brusca de tratamento vital (ex. hemodiálise) e até mesmo o suicídio, considerado como o mais extremo dos atos autodestrutivos. Já a automutilação seria um dos tipos possíveis de manifestação dessas práticas, uma forma direta e voluntária de autodestruição. Ela pode ser realizada com ou sem a ajuda de objetos externos e também comporta subtipos, dentre os quais destacamos as práticas de escarificações (também conhecidas pelo termo cutting), queimaduras, arranhões, abrasões cutâneas e escoriações.

As escarificações são as automutilações mais frequentemente encontradas na clínica (Favazza, 1987/2011; Suyemoto \& Macdonald, 1995; Richard, 2005). Podem ser definidas como a presença de um ou vários cortes realizados no próprio corpo de forma intencional, tendo como consequência feridas que deixam marcas entalhadas no corpo (Pommerau, Brun \& Moutte, 2009). As incisões costumam ser superficiais e sem intenção de morte e é importante diferenciá-las da flebotomia, prática na qual são realizados um ou mais cortes profundos na veia, normalmente nos punhos e vinculados a uma intenção de morte (De Luca, Bonnichon \& Marty, 2012). As escarificações foram inicialmente descritas em 1969 pelo psiquiatra Pao, que frisou a existência de dois grandes grupos de cutters: o primeiro, que realizava apenas um grande corte profundo próximo a vias importantes de circulação de sangue, não costumando repetir o ato; e o segundo, que realizava uma série de cortes superficiais e delicados no corpo, ocorrendo de forma repetitiva.

Complementando a descrição, evocamos também Dargent e Matha (2011), que apontam para a etimologia do termo "escarificação": ele é derivado do grego skaripheuein (incisão) e do latim sacrificare (sacrificar) e scribere (escrever). Se, por um lado, a palavra se encontra ligada a uma ideia destrutiva de abrir cortes na pele, por outro, ela chama atenção para o caráter de inscrição deixado por estas marcas enigmáticas. 
Inicialmente, o termo escarificação era utilizado para descrever duas práticas bastante distintas: 1) um tratamento médico ligado a uma ideia de purificação do sangue como tentativa de curar certas doenças e condições (sangria); 2) ritos de passagem de sociedades tribais para designar e comunicar aos outros integrantes alguma característica daquele membro do grupo através das cicatrizes deixadas. A partir da metade do séc. XX, a escarificação foi redescoberta pelos artistas do Body Modification, contendo agora uma finalidade estética. Estes artistas se aprofundaram na técnica de deixar marcas e desenhos específicos sobre a pele do sujeito com o auxílio de bisturis cirúrgicos (Araujo, 2005). A técnica tem caráter de permanência maior do que a tatuagem, uma vez que deixa rastros tridimensionais no corpo, impossíveis de serem retirados posteriormente.

O segundo fenômeno de maior frequência no âmbito das automutilações é o das queimaduras (Richard, 2005). Este diz respeito a casos mais extremos e em menor número do que os cortes, resultado da ação do fogo diretamente na pele ou do uso de algum produto abrasivo - frequentemente queimaduras de cigarro ou por uso de substâncias presentes em sprays. Essas feridas costumam ser profundas e ter uma cicatrização mais difícil. Os casos de queimadura normalmente apontam para sofrimentos psíquicos mais graves, condizendo com o tipo de ferida deixada, que é bastante complexo e de difícil cicatrização.

Outro fenômeno destacado por nós como parte do universo das automutilações é o das abrasões cutâneas e das escoriações. Pommereau (2006b) o descreve como feridas causadas por fricção ou raspagem feitas na pele de forma repetida, geralmente com as unhas ou objetos rugosos, produzindo marcas que podem se estender sobre todo o antebraço ou nas pernas. As abrasões cutâneas são menos frequentes do que os cortes e as queimaduras, podendo aparecer em conjunto com estes ou separadas. As escoriações são ferimentos causados por autoagressões que podem ser fruto de arranhões ou machucados deixados no próprio corpo advindos do encontro com algum objeto duro, normalmente paredes, armários e espelhos, que costumam deixar hematomas.

Como última contribuição classificatória para os subtipos de automutilação, evocamos o chamado skin picking, que consiste em beliscar a própria pele de forma a deixar feridas, seja pela manipulação de um machucado pré-existente (picada de insetos ou acne) ou criando novos ferimentos e 
interferindo com sua cicatrização. Nesta categoria também podemos inserir o arrancar de peles no entorno das unhas, ato que vai além da onicofagia, uma vez que a pele ao redor fica machucada.

Tais comportamentos anteriormente descritos caracterizam os subtipos da automutilação que serão considerados no presente trabalho. Baseamo-nos em práticas automutilatórias nas quais há uma ruptura da integridade do tecido epitelial, sendo que a descontinuidade da pele seria a principal característica a ser destacada.

É comum que o sujeito utilize mais de um método de automutilação em momentos diferentes e os locais de incidência mais frequentes são os punhos, antebraço, coxas, pernas, barriga e áreas frontais do corpo, uma vez que são de mais fácil acesso. Na maior parte dos casos, há um aumento de tensão, raiva, ansiedade e tristeza antes do ato. Sentimentos de rejeição, abandono (real ou imaginário), culpa e sensação de vazio. Posteriormente, viriam sensações momentâneas de alívio e de diminuição de tensão que podem estar acompanhadas ou não de sentimentos de culpa, arrependimento e vergonha por terem praticado tais atos.

Dando continuidade ao capítulo, vamos apresentar uma descrição do campo de estudos referente à automutilação e os principais pontos de convergência abordados por autores de referência nesta área, com o objetivo de traçar um panorama da automutilação que nos permita adentrar nas discussões e hipóteses propostas no presente trabalho. Começaremos realizando um breve passeio histórico pelas classificações nosográficas que levaram em conta o fenômeno das automutilações ao longo da história, especialmente no campo da psiquiatria.

\section{2 \\ Breve passeio histórico pelas classificações existentes}

O fenômeno da automutilação vem sendo estudado pela Psiquiatria desde o séc. XIX, tendo como marco inicial a publicação do livro de Léopold Galais, em 1867, intitulado Des mutilations chez les aliénés. Pour servir à l'histoire de l'altération de la sensibilité chez ces malades. Na sequência, Richard Millant publica, em 1902, Castration criminelle et maniaque: étude historique et médico- 
légale, e Charles Blondel, em 1906, Les automutilateurs: étude psychopathologique et médico-légale. Em 1909, Marie Michel Lorthiois publica o livro intitulado De l'automutilation: mutilations et suicides étranges, no qual consta uma primeira definição mais apurada do termo "automutilação" (Scaramozzino, 2004).

De acordo com a definição de Lorthiois (1909), a automutilação é caracterizada como uma lesão feita pela própria pessoa em seus tecidos ou órgãos e um ataque à integridade do corpo. Ela pode consistir em uma ferida ou na ablação total ou parcial de um órgão ou de um membro, do revestimento cutâneo ou de seus anexos, podendo comprometer a vitalidade e o bom funcionamento dos mesmos, sem ter como objetivo provocar a própria morte com este comportamento. Em viés similar às definições mais atuais sobre o tema, a autora classifica ainda a automutilação como um comportamento que pode ser voluntário (quando a intenção de se fazer mal se encontra presente) ou involuntário (quando o comportamento aparece como resultado de um automatismo e é realizado sem que a pessoa se dê conta do que está fazendo); direto (realizado pela própria pessoa) ou indireto (em um contexto no qual outras pessoas a influenciem); e individual (sujeito isolado ao praticar o ato) ou coletivo (na presença de outros ou de forma que a coletividade compartilhe crenças e ideias que levem a pessoa a realizar tal ato).

Outra definição de automutilação descrita historicamente ocorreu no período da Primeira Guerra Mundial, no qual soldados se feriam propositalmente para escapar das trincheiras - chamado de Malingering. Estas automutilações tomavam uma forma específica e tinham como objetivo a dispensa dos serviços de guerra, já que as feridas levavam a um tempo de internação hospitalar, no qual estariam afastados de suas funções militares. As automutilações mais comuns neste contexto advinham de ferimentos causados por um tiro nas mãos ou nos pés e infecções nos olhos causadas por contato com elementos químicos. Estes soldados eram frequentemente enviados para hospitais especiais e passavam por um processo de julgamento e punição por tentativa de evasão (Narjisse, 2014).

O fenômeno das automutilações também foi descrito por Karl Menninger, psiquiatra norte-americano. Em seu livro Eros e tânatos: o homem contra si próprio (1938/1970), Menninger propõe uma discussão sobre a destrutividade do homem e as diferentes formas que ela poderia tomar. Ele faz uma diferenciação 
entre o suicídio propriamente dito e outros comportamentos destrutivos que prejudicariam o sujeito sem levá-lo diretamente a óbito. Na visão do autor, o impulso suicida poderia se concentrar apenas sobre uma parte do próprio corpo, ao invés de se concentrar no todo - como nos suicídios em geral. Para designar este tipo de comportamento, o autor criou a categoria do suicídio focal, a qual engloba como um de seus subtópicos o fenômeno da automutilação. De acordo com o autor, a automutilação seria equivalente a direcionar um impulso suicida para uma parte específica do corpo, ao invés de deixá-lo atingir a totalidade deste.

Até 1909, com as descrições de Lorthiois sobre os fenômenos de automutilação, percebemos que estes fenômenos eram descritos apenas em casos de doenças psíquicas graves como a esquizofrenia, a psicose maníaco-depressiva e a melancolia, não sendo descritos casos fora do espectro da psicose (com exceção das descrições antropológicas de tribos nas quais este comportamento marca um rito de passagem ou a tentativa de proximidade com alguma divindade superior). A partir dos estudos de Menninger (1938/1970), podemos perceber que o espectro se abre para a recepção de casos variados, incluindo o campo das neuroses.

De acordo com o autor, a automutilação pode ser definida como "(1) os ataques destrutivos deliberados a várias partes do corpo com que estamos mais familiarizados nas formas extremas e bizarras às vezes manifestadas por pacientes em hospitais mentais" (p. 207), em conformidade com as definições anteriores de outros autores. Contudo, o autor complementa:

\begin{abstract}
Na mesma categoria, não podemos omitir (2) as várias formas de ferimento corporal autoinfligidos a que são dados os neuróticos. Morder as unhas, por exemplo, fica um grau aquém de morder os dedos e alguns indivíduos têm a compulsão de morderem-se mais ou menos severamente em várias outras partes do corpo. Outros se arranham ou cravam as unhas incessantemente na própria carne, arrancam os cabelos ou esfregam os olhos e a pele a ponto de causar inflamação. (p. 207-208)
\end{abstract}

Dessa forma, podemos perceber que, desde o início das discussões propostas, já havia espaço para pensarmos a automutilação como uma conduta que perpassa diferentes quadros psicopatológicos.

A partir da década de 1960, houve um aumento na produção acadêmica sobre o assunto, especialmente nos Estados Unidos, de forma que diferentes termos e fenômenos começaram a ser descritos. Um maior número de pesquisadores se voltou para um subtipo presente nas automutilações: o fenômeno dos cortes realizados nos punhos, descritos como escarificação ou cutting. Da 
mesma forma, o fenômeno começa a ser descrito como "síndrome" por diferentes pesquisadores, vindo a ocupar um lugar diferenciado nas classificações psicopatológicas.

Em 1969, o psiquiatra chinês Ping-Nie Pao publicou um estudo que culminou na classificação de dois padrões encontrados em indivíduos que se escarificavam: o primeiro é composto pela realização de cortes no próprio corpo de forma "delicada" e repetitiva, enquanto o segundo padrão diz respeito à realização de um único corte mais profundo, de forma "grosseira", sem a característica de repetição do comportamento (costumam ser episódios únicos).

Desta pesquisa, surge a Syndrome of Delicate Self-Cutting, ou "síndrome da escarificação delicada", fazendo referência a indivíduos que cortavam apenas a superfície de sua pele, majoritariamente os punhos. Estes indivíduos teriam idade menor do que o segundo grupo e estreita relação com o diagnóstico de transtorno de personalidade borderline, enquanto os indivíduos praticantes da "automutilação grosseira" teriam idade mais avançada e relação com o diagnóstico de psicose (Pao, 1969; Burešová, 2016).

Em 1972, Rosenthal e colaboradores descrevem a Síndrome dos Cortadores de Punho, classificando mulheres que teriam mais de cinco episódios de cortes nos punhos. Entretanto, nos estudos realizados, ficou claro que estas pacientes não restringiam as automutilações a cortes no punho, mas podiam ferir ainda partes diversas do corpo, provocar fraturas em ossos, arranhar e escavar suas faces, assim como esfregar pedaços de vidro na própria pele. As pacientes descreviam sensações de vazio e inutilidade antes de se machucarem e, após, uma sensação de alívio.

No final da década de 1970, Ross e McKay (1979) introduzem as automutilações em uma classificação mais ampla de autoagressão direta, na qual o sujeito faz mal para si mesmo de forma deliberada. Esta classificação inclui comportamentos como se cortar, se morder, esfregar a pele em excesso, cortar partes do próprio corpo, inserir objetos na pele, se queimar, engolir ou inalar objetos perigosos, se bater ou se estrangular. Esta se diferencia da autoagressão indireta, na qual o sujeito faz mal a si mesmo através de outros comportamentos indiretos, porém igualmente danosos - como uso excessivo de drogas, por exemplo (Burešová, 2016). 
Em seu livro intitulado Self-mutilation, Ross e McKay (1979) repertoriaram mais de trinta termos para designar diferentes comportamentos autoagressivos. Nestes, encontramos diversos atos realizados contra o próprio sujeito, de forma direta ou indireta, tais como o suicídio, o uso de substâncias tóxicas e a interrupção de tratamentos vitais para a vida dentro de um quadro de doença orgânica crônica. Os autores partem de um grupo mais abrangente na direção de comportamentos específicos de autodestruição e os dividiram em três grandes grupos: comportamentos de autolesão (self-injurious behavior), automutilação (self-mutilation) e comportamentos autodestrutivos (selfdestructive behavior). A automutilação aqui é delimitada por características específicas de autolesão ao próprio corpo de forma intencional e deliberada (Gicquel \& Corcos, 2011).

Na mesma direção, Pattison e Kahan (1983) apresentam uma gama mais ampla do que chamaram de comportamentos autodestrutivos (self-harming behaviour), sendo estes classificados por três fatores: 1) caráter direto ou indireto do ato; 2) nível de letalidade (alta, média ou baixa); e 3) aspecto repetitivo do comportamento. Para os autores, estes atos seguem uma continuidade de espectro que vai desde as automutilações até o suicídio. Outros atos descritos são as condutas de exposição ao risco, alcoolismo crônico, abuso de substâncias, interrupção de tratamento vital, obesidade, dentre outros, bem similares aos comportamentos autoagressivos descritos por Ross e McKay (1979).

Dentro deste quadro mais amplo, Pattison e Kahan (1983) propõem que as automutilações sejam enquadradas como uma síndrome que, de acordo com seus parâmetros, seria de caráter direto, com nível de letalidade baixo e aspecto repetitivo de comportamento. A chamada Deliberate Self-harm Syndrom, ou "Síndrome da autoagressão deliberada (SAD)" é descrita como um distúrbio severo e incontrolável do impulso, que possui início na adolescência e se caracteriza por episódios repetidos de automutilação de baixa letalidade, em especial cortes e queimaduras, a perdurar por vários anos. Outra característica da síndrome é uma sensação de alívio posterior e a não intenção suicida consciente. A proposta dos autores ao descrever esta síndrome era a de incluí-la como entidade específica na categoria do DSM-IV consagrada aos Transtornos do controle de impulso não classificados (Gicquel \& Corcos, 2011; Giusti, 2013). 
Dessa forma, podemos perceber, com o aumento da produção de pesquisas sobre os comportamentos autodestrutivos e os fenômenos de automutilação a partir da déc. 1960, um esforço realizado pelos autores na direção da criação de uma nosologia psiquiátrica que introduza as automutilações em um registro sindrômico. Se, até o momento, elas estavam em um registro descritivo, passeando por diversos quadros psicopatológicos, aqui elas começam a ganhar estatuto de síndrome. Esse movimento permanece ao longo da história e ganha força com Armando Favazza e Barent Walsh na déc. 1980.

Armando Favazza (1987/2011) é um psiquiatra norte americano contemporâneo, cuja classificação de automutilações é a mais conhecida e utilizada nas pesquisas, tendo se tornado referência nos estudos sobre a temática. Nos anos 1980, o autor sintetiza em uma classificação mais robusta sobre as automutilações toda a discussão que vinha ganhando corpo até então entre os pesquisadores anteriormente citados. Em seu livro Bodies under siege, o autor discute uma série de temas como automutilação, comportamentos autoagressivos, body modification e sua relação com a cultura e com a Psiquiatria. Ele se classifica como um "psiquiatra cultural”, ou seja, um profissional que leva em conta, dentro de seu saber médico e psiquiátrico, a existência de outras culturas e suas diferentes nuances.

Ao se voltar para a temática das automutilações, o autor aborda a aparição deste fenômeno em situações que vão além do universo da Psiquiatria, como, por exemplo, na religião. $\mathrm{O}$ autor discorre sobre a forma pela qual, em diferentes religiões, podemos ver a espiritualidade e as crenças religiosas sendo utilizadas como método de aproximação do divino através de práticas automutilatórias. Outros campos de correlação apontados pelo autor são a Etologia, na forma pela qual as automutilações ocorrem nos animais, e a Antropologia, descrevendo diferentes ritos de passagens tribais que fazem uso desta prática.

Dentro do terreno da Psiquiatria, Favazza (1987/2011) reagrupa as automutilações em três grandes categorias fenomenológicas:

1) Automutilação maior: são atos mais graves e de baixa frequência, tais como a enucleação ${ }^{1}$, castração ou amputação de membros, que apontam para

\footnotetext{
${ }^{1}$ Termo utilizado na literatura médica para referir-se à retirada de um órgão, tumor ou outro corpo, de tal maneira que saia inteiriço, por intermédio cirúrgico. No caso destas automutilações
} 
danos corporais importantes. Tais atos costumam ocorrer uma única vez, pois a gravidade leva a um atendimento médico de emergência e, posteriormente, acompanhamento psiquiátrico. Também costumam ser atos irreversíveis e impensados, sem planejamento prévio. Essa categoria de automutilação é mais frequentemente associada a casos de psicose ou a casos de intoxicação aguda por substância;

2) Automutilação estereotipada: são atos como se bater, bater a cabeça na parede, apertar os olhos violentamente, se morder (as partes mais frequentes são lábios, língua, bochecha e dedos) e/ou arrancar os cabelos de forma monótona, repetitiva e com padrão rítmico de movimento. Costumam estar associados a quadros de retardo mental, ou a síndromes que tenham o retardo como traço marcante, como a síndrome de Rett e a síndrome de Lange, e a quadros de autismo. Também podem estar associados a descompensações psicóticas agudas, doenças associadas a neuropatias hereditárias ou à síndrome de Tourrete e à síndrome de Lange;

3) Automutilação superficial/moderada: são atos de machucar a própria pele de forma superficial de diferentes modos. São consideradas como as de menor gravidade na classificação devido ao tamanho e à frequência das lesões, porém nos dão notícias de um fenômeno preocupante e crescente ao redor do mundo. Costumam surgir no período da adolescência e dividem-se em:

3.1) compulsiva: são atos frequentemente repetidos e ritualizados, ocorrendo diversas vezes ao longo do dia. Há uma busca por reduzir a tensão e a ansiedade e tais atos são precedidos por sensação reconfortante de alívio. Abarcam os fenômenos da esfera do Transtorno Obsessivo Compulsivo, tais como a tricotilomania e a onicofagia;

3.2) impulsiva: são as condutas mais comumente observadas, geralmente tratando-se de cortes, queimaduras, arranhões, beliscar a pele, mexer em machucados já em processo de cicatrização e/ou escoriações autoinfligidas. Nestes casos, haveria uma impossibilidade em resistir ao impulso de se machucar, já que o sujeito experimenta uma ansiedade que cresce exponencialmente até o momento de realização do ato. As impulsivas também podem se dividir em:

a) episódica: com um número reduzido de ocorrências ao longo da vida; 
b) repetitiva: cuja frequência torna-se maior, de forma que o autor propõe reunir as condutas deste subtópico no que chamou de Síndrome das Automutilações Repetidas (SAR).

A passagem das automutilações superficiais/moderadas impulsivas episódicas para as repetitivas não se configura a partir de um número fixo ou prédeterminado, mas de acordo com a relação entre o sujeito e seus comportamentos automutilatórios. Para que se configure a SAR, faz-se necessário que o paciente tenha preocupação exagerada em se fazer mal e que possua ainda relação de adição com as automutilações, de forma que não consiga resistir ao impulso de se automutilar. O início data da adolescência e costuma persistir por décadas, contendo períodos de maior ou menor frequência de atos automutilatórios. Como o autor considera a SAR uma síndrome relativa à esfera da impulsividade, outros comportamentos impulsivos podem aparecer em comorbidade: transtornos alimentares, abuso de substâncias e cleptomania são os mais frequentes, destacados por ele.

Para a proposta da SAR, Favazza (1987/2011) diz ter utilizado como base o modelo sindrômico de Pattison e Kahan (1983) e o aprimorado, criando uma síndrome mais específica, que afunila os comportamentos autoagressivos, levando em conta apenas os que contêm atos de automutilação. Da mesma forma que os anteriores, Favazza (1987/2011) tinha por objetivo, ao descrever a SAR, a inclusão desta nova síndrome no DSM-IV, na esfera de Transtornos do controle de impulso não classificados.

Partindo da classificação das automutilações descrita por Favazza (1987/2011), podemos compreendê-las como fenômenos que podem pertencer a psicopatologias distintas, possuindo uma gama bastante ampla que vai desde os quadros clínicos da psicose aos quadros clínicos da neurose, passando pelos casos limites. Se, por um lado, a classificação do autor leva em conta a proposta de agrupar alguns tipos de automutilações como uma síndrome, por outro, ela abre caminho para observarmos o caráter transnosográfico da automutilação, uma vez que este fenômeno pode estar ligado a quadros clínicos bastante distintos.

Segundo Favazza (1987/2011), para cada um dos três eixos de subdivisão nos quais ele encontra a presença de automutilações há uma psicopatologia proeminente. No caso das automutilações maiores, nas quais há um dano físico maior resultante deste comportamento, o autor faz referência aos quadros 
psicóticos ou de intoxicação aguda por substâncias. Já nas automutilações estereotipadas, o enfoque está na repetição de um comportamento danoso que possui como característica principal a existência de um ritmo, que guia o movimento autoagressivo, e o autor coloca como paradigma o autismo e algumas síndromes metabólicas. Quando descreve as automutilações superficiais/moderadas, o autor faz referência a comportamentos autolesivos que se aproximam dos quadros de neurose e dos casos limite.

Entretanto, quando o autor descreve a SAR, ele observa que há um padrão de comportamento diferenciado envolvendo este fenômeno a ponto de propor uma entidade nosológica própria. Dessa forma, mesmo que as automutilações estejam presentes em quadros variados, exibindo seu caráter transnosográfico, é importante ressaltar a existência de um aglomerado de sinais e sintomas observados por alguns autores que vão configurar, a partir de comportamentos específicos automutilatórios, uma psicopatologia também própria das automutilações.

\section{3}

\section{Síndrome x sintoma: o estatuto das automutilações}

Desde o início dos estudos sobre a automutilação, percebemos que uma das grandes questões que se coloca para os pesquisadores é sobre o estatuto do fenômeno. Tratar-se-ia apenas de um sintoma, prevalente em diferentes quadros clínicos, ou estaríamos falando de uma síndrome, entidade clínica diferenciada que afunila e congrega outros comportamentos? De acordo com Dalgalarrondo (2008), uma síndrome pode ser definida como um "conjunto de sinais e sintomas que se agrupam de forma recorrente e são observadas na prática clínica diária” (p. 301). A partir desta definição, podemos seguir com a reflexão acerca do estatuto das automutilações discutindo algumas classificações existentes ao longo da história do fenômeno.

Apesar do termo síndrome já ter aparecido com a síndrome da escarificação delicada de Pao na déc. 1960, é apenas a partir da déc. 1980, com Pattison e Kahan e com Armando Favazza, que começa a haver uma tentativa de mudança no modo de compreender a prática da automutilação dentro da Psiquiatria. Apesar de não haver um consenso entre os diferentes pesquisadores 
do fenômeno, a partir de 1980 observamos o crescimento no número de pesquisas nas quais a automutilação é considerada como um fenômeno próprio de uma entidade clínica separada, englobando outros sinais e sintomas (Ferreira, 2014).

$\mathrm{Na}$ contramão desta tentativa de singularização da automutilação, os manuais classificatórios não a apresentavam, até pouquíssimo tempo atrás, como uma entidade nosográfica separada de outras doenças, classificando tais comportamentos apenas na forma de sintomas, espalhados por diferentes psicopatologias. Segundo Gicquel e Corcos (2011), a principal questão, até hoje, é a de saber se devemos agrupar os comportamentos automutilatórios como uma entidade clínica autônoma e separada ou como parte integrante, na forma sintomática, de síndromes e transtornos clínicos variados.

No manual de Psicopatologia e semiologia dos transtornos mentais de Dalgalarrondo (2008), encontramos a automutilação como uma alteração na esfera da vontade e da psicomotricidade, mais especificamente no item Impulsos $e$ compulsões agressivas auto ou heterodestrutivas, descrita como:

\begin{abstract}
o impulso (ou compulsão) seguido de comportamento de autolesão voluntária. São pacientes que produzem escoriações na pele e nas mucosas, furam os braços com pregos e pedaços de vidro, arrancam os cabelos (tricotilomania), etc. As automutilações leves e moderadas são observadas em indivíduos com transtorno de personalidade borderline, naqueles com transtorno obsessivo-compulsivo e em alguns deficientes mentais. As formas mais graves de automutilação em psiquiatria são a auto-enucleação (extração do próprio olho) e a auto-amputação do pênis, que ocorrem em pacientes psicóticos, geralmente esquizofrênicos em estado alucinatório-delirante e indivíduos com psicoses tóxicas, produzidas por alucinógenos. (p.179)
\end{abstract}

Esta definição parece levar em conta a ideia de autores como Favazza (1987/2011) e Pattison e Kahan (1983), que classificam um grande espectro de comportamentos e psicopatologias dentro da seara das automutilações. Apesar dos termos não serem exatamente os mesmos, o manual leva em conta a existência de automutilações leves, moderadas e graves e as relaciona com diferentes quadros psicopatológicos, de forma bastante similar às definições de Favazza (1987/2011) acerca das automutilações maiores, estereotipadas e superficiais.

Importante ressaltarmos que, mesmo antes de as automutilações adquirirem um estatuto mais próximo do sindrômico em nossos manuais classificatórios, elas já se encontravam ali presentes há bastante tempo, porém apareciam de forma dispersa e fragmentada, passando por vezes despercebidas, em diversas categorias diagnósticas. Interessante percebermos como, ao longo do tempo, estes comportamentos que apareciam dispersos vão se configurando 
lentamente de forma a convergir no surgimento de síndromes e/ou transtornos mais organizados e autônomos que levam no centro as automutilações.

De acordo com a décima edição da Classificação Internacional de Doenças, o CID 10 (OMS, 1993/2011), podemos encontrar os comportamentos automutilatórios citados de forma indireta ao longo do manual, como sintomas possivelmente presentes em quatro grandes categorias:

1) Transtornos de personalidade e de comportamentos em adultos:

a. F60.31 Transtorno de personalidade emocionalmente instável do tipo borderline:

Uma propensão a se envolver em relacionamentos intensos e instáveis pode causar repetidas crises emocionais e pode estar associada com esforços excessivos para evitar abandono e uma série de ameaças de suicídio ou atos de autolesão (embora estes possam ocorrer sem precipitantes óbvios). (OMS, 1993/2011, p. 200-201, grifos nossos)

\section{b. F63.3 Tricotilomania:}

Um transtorno caracterizado por notável perda de cabelo devido a uma falha recorrente de resistir a impulsos de arrancá-lo. O arrancar de cabelos é usualmente precedido por tensão crescente e seguido por uma sensação de alívio ou satisfação. (OMS, 1993/2011, p. 209, grifos nossos)

2) Transtornos do desenvolvimento psicológico (F80-F89):

a. F84.0 Autismo infantil:

Em adição a esses aspectos diagnósticos específicos, é frequente a criança com autismo mostra uma série de outros problemas não específicos tais como medo/fobia, perturbações de sono e alimentação, ataques de birra e agressão. Autolesão (p. ex., morder o punho) é bastante comum, especialmente quando há retardo mental grave associado. (OMS, $1993 / 2011$, p. 248, grifos nossos)

3) Transtornos emocionais e de comportamento com início usualmente ocorrendo na infância e adolescência (F90-98):

a. F98.4 Transtorno de movimento estereotipado:

Movimentos voluntários repetitivos, estereotipados, não funcionais (com frequência rítmicos) que não fazem parte de nenhuma condição neurológica ou psiquiátrica reconhecida. (...) Movimentos estereotipados autoagressivos incluem: golpear a cabeça repetidamente, dar tapas no rosto, enfiar o dedo nos olhos, morder as mãos, lábios ou outras partes do corpo. (OMS, 1993/2011, p. 282, grifos nossos)

4) X60-X84 - Autolesão intencional "envenenamento ou lesão autoinfligida propositalmente" (OMS, 1993/2011, p. 295), que incluem, além do envenenamento, atos como autolesão causada por objeto cortante, por enforcamento, por tentativa de afogamento etc. 
A quinta edição do Manual de Diagnóstico e Estatístico de Transtornos Mentais, o DSM-5 (American Psychiatric Association, 2014), também aponta comportamentos automutilatórios como sintomas possivelmente presentes dentro de outros transtornos, assim como o CID-10. Boa parte destes transtornos coincide com a Classificação Internacional de Doenças, de forma que são correspondentes o Transtorno do Espectro Autista 299.00 (F84.0), a Tricotilomania 312.39 (F63.3) e o Transtorno de movimento estereotipado 307.3 (F98.4). No Transtorno da Personalidade Borderline 301.83 (F60.3), o DSM-5 vai além do CID-10 e aponta a automutilação como um dos critérios diagnósticos para o transtorno: "5) Recorrência de comportamento, gestos ou ameaças suicidas ou de comportamento automutilante" (American Psychiatric Association, 2014, p. $663)$.

Para além dos transtornos citados com correspondência no CID-10, o DSM-5 aponta ainda uma nova categoria, na qual a automutilação aparece com lugar privilegiado: o Transtorno de Escoriação (Skin-picking) 698.4 (L98.1). Este transtorno é marcado por comportamento recorrente de beliscar a própria pele, de forma a provocar lesões cutâneas:

\footnotetext{
Podem beliscar pele saudável, irregularidades menores na pele, lesões como espinhas ou calosidades ou cascas de lesões anteriores. A maioria das pessoas belisca com as unhas, embora muitas usem pinças, alfinetes ou outros objetos. Além de beliscar a pele, pode haver comportamentos de esfregar, espremer e morder. Os indivíduos com transtorno de escoriação frequentemente passam quantidades significativas de tempo em seu comportamento de beliscar, às vezes várias horas por dia, e esse comportamento pode durar meses ou anos. (p.254-255)
}

Até o momento, os manuais classificatórios vinham apresentando a automutilação de forma fragmentada, como possível sintoma integrante de transtornos clínicos diversos. Entretanto, o DSM-5 traz uma novidade relativa à classificação das automutilações. Gostaríamos de lançar luz sobre uma discussão proposta no final do manual, no item Condições para estudos posteriores. Este capítulo é reservado para apresentar conjuntos de critérios para os quais são encorajadas futuras pesquisas com a finalidade de os itens descritos serem incluídos nas próximas edições do DSM.

Nesta seção, encontramos a descrição de um transtorno chamado Autolesão Não Suicida, em inglês Non-Suicidal Self-Injury (NSSI). Pela primeira vez, nos manuais, a automutilação aparece como fenômeno que possui autonomia própria. Sabemos que ambas as formas são encontradas na literatura desde o 
princípio de seus estudos, mas esse novo transtorno incluído no Manual marca uma diferença na forma de compreender o fenômeno.

A nomenclatura NSSI vem sendo bastante utilizada em artigos sobre o assunto, especialmente nos países de língua inglesa. Sua definição é a seguinte:

o comportamento repetido do próprio indivíduo de infligir lesões superficiais, embora dolorosas, à superfície do seu corpo. [...] Os ferimentos infligidos podem se tomar mais profundos e mais numerosos. A lesão é mais frequentemente infligida com uma faca, agulha, lâmina ou outro objeto afiado. Locais comuns para lesão incluem a área frontal das coxas e o lado dorsal do antebraço. Uma única sessão de lesão pode envolver uma série de cortes paralelos superficiais - separados por 1 ou 2 centímetros - em um local visível ou acessível. Os cortes resultantes com frequência irão sangrar e eventualmente deixarão um padrão de cicatrizes característico. Outros métodos utilizados incluem fincar uma agulha ou faca de ponta afiada em uma área, em geral na parte superior do braço; infligir uma queimadura superficial com a ponta de um cigarro aceso; ou queimar a pele esfregando repetidamente uma borracha. (p. 804)

De acordo com o Manual, há um dano intencional autoinfligido à superfície do corpo, porém não há, neste comportamento, a presença de ideação suicida. O indivíduo espera que a lesão gere somente um dano físico menor ou moderado, não ocorrendo o óbito. A autolesão também deve cumprir o critério de não ser socialmente aceita, como são, por exemplo, os piercings e as tatuagens. De acordo com o Manual, as expectativas com a autolesão seriam: 1) Obter alívio de um estado de sentimento ou de cognição negativos; 2) Resolver uma dificuldade interpessoal; ou 3) Induzir um estado de sentimento positivo.

Diferentemente do que vínhamos observando até este momento nos manuais classificatórios, o DSM-5 propõe classificarmos as automutilações (Autolesão Não Suicida) como entidade nosográfica separada de outros transtornos, conferindo a elas o estatuto de entidade clínica autônoma. Na mesma direção de alguns autores citados anteriormente, como Pao (1969), Rosenthal e colaboradores (1972), Favazza (1987/2011) e Pattison e Kahan (1983), o DSM-5 corrobora a ideia de pensarmos as automutilações não apenas como sintomas que podem ocorrer em transtornos variados, mas com um corpo próprio.

De maneira geral, podemos compreender que o fenômeno das automutilações existe de forma recorrente na clínica em suas duas formas: fragmentada, corroborando a ideia de um fenômeno transnosográfico e plural; assim como autônoma, com características próprias que convergem para uma compreensão mais sindrômica deste comportamento. Uma forma de aparecimento 
não invalida e nem enfraquece a outra. Ambas são possíveis e podem ser compreendidas dentro de suas limitações teóricas.

Mesmo reconhecendo o esforço realizado para clarificar o solo das automutilações, sabemos que a proposta desses manuais é a de apresentar uma classificação descritiva, que não fornece possíveis motivações nem compreensão das problemáticas subjacentes a esses fenômenos. Se, por um lado, é importante concordarmos sobre a definição acerca do campo de estudos escolhido, por outro, faz-se ainda necessário maior exploração sobre o tema no que diz respeito a causas e consequências dessas práticas.

Com o intuito de defender a ideia apresentada, nos propomos a delimitar nosso objeto de estudo. Acreditamos que não seria produtivo abordarmos, neste trabalho, todos os tipos existentes de automutilação. Cada subtipo abre portas para pensarmos problemáticas específicas, densas e bastante diferentes entre si. Nesse sentido, optamos por realizar um recorte teórico que terá como base a classificação de Armando Favazza (1987/2011), abordando apenas as automutilações superficiais/moderadas, incluindo as automutilações compulsivas e impulsivas.

Dessa forma, ficam incluídas no presente trabalho todas as automutilações que dizem respeito a cortes, queimaduras, arranhões e escoriações autoprovocadas, mas encontram-se excluídos os comportamentos mais graves como amputação de membros, enucleação, autocastração, assim como comportamentos repetitivos que estejam relacionados com a esfera do autismo, do retardo mental e das síndromes metabólicas citadas pelo autor. Entendemos que, mesmo com a pluralidade de formas aparentes das automutilações, faz-se necessária a delimitação do campo para melhor compreensão das propostas desta pesquisa.

Outro ponto de partida para as reflexões a serem abordadas diz respeito a uma maior compreensão da problemática apresentada. Apesar da discussão sobre o estatuto da automutilação ocupar grande espaço entre os teóricos de referência no assunto, gostaríamos de ir além de uma compreensão reduzida em termos do estatuto do fenômeno e nos voltarmos para a reflexão do que podemos apreender a partir destas condutas destrutivas. Dentro de nosso entendimento, com base especialmente no terreno da clínica, apostamos na ideia de que os fenômenos automutilatórios, apesar de causarem dor e sofrimento, também constituem o 
sujeito, em sua maneira mais primitiva de ser. Essas "autoferidas" sustentam algo de suas vivências precoces, auxiliando-os a manterem-se vivos, a sentirem que existem e são contínuos ao longo do tempo e do espaço.

Conforme apresentamos ao longo deste subtópico, o fato de o terreno das automutilações não ser homogêneo e possuir uma série de diferentes formatos chama a atenção para outra discussão importante neste campo, especialmente no que diz respeito a sua definição: a tentativa, existente em diversos autores, de diferenciar os comportamentos automutilatórios de possíveis comportamentos suicidários. Apesar de encontrarmos estudos que sugerem um aumento de risco de suicídio em um sujeito que se automutila, a maioria sugere que há caráter de "proteção" contra o suicídio nos comportamentos automutilatórios.

\section{4 \\ Aproximações e diferenças entre a automutilação e o comportamento suicidário}

Ao adentrarmos na literatura existente sobre a automutilação, percebemos uma característica comum que perpassa todas as descrições psiquiátricas e psicanalíticas do fenômeno, em diferentes países: a tentativa de diferenciar a automutilação de um comportamento suicidário. Como ambos estão localizados dentro da esfera de comportamentos autodestrutivos e costumam aparecer simultaneamente em algum momento da história dos pacientes, há uma grande discussão no que diz respeito às similaridades e às diferenças existentes entre esses dois fenômenos.

Podemos perceber uma preocupação em diferenciar ambos os comportamentos já na definição de automutilação apresentada por Lorthiois (1909), na qual a autora afirma haver aproximação dos comportamentos, porém ressalta uma diferença significativa em relação aos motivos que levam a cada um desses atos. Menninger (1938/1970) também os diferencia, mas os descreve de outra forma, criando a categoria do suicídio focal para se referir às automutilações. Pao (1969) também diferencia ambos, criando a síndrome da automutilação delicada e afirmando que a automutilação não apenas se diferenciaria, mas também protegeria os sujeitos que a realizam do suicídio propriamente dito. Feldman (1988) sugere que, na maioria dos casos, os próprios 
sujeitos diferenciam cognitivamente suas condutas automutilatórias de tentativas de suicídio, esclarecendo as diferenças entre ambas.

Dentro da discussão proposta, alguns autores acreditam que as diferenças existentes entre a automutilação e a tentativa de suicídio são de ordem quantitativa, descrevendo um contínuo de autodestruição que vai da automutilação ao suicídio propriamente dito, tais como Ross e McKay (1979) e Pattison e Kahan (1983), assim como estudos mais atuais que dão continuidade a essas pesquisas, como os de Sinclair e Green (2005). Outros autores acreditam se tratar de problemáticas distintas, marcadas por uma diferença de ordem qualitativa, e apontam a automutilação como uma espécie de barreira protetora contra o suicídio, último recurso radical contra o ataque total ao corpo.

Dando subsídios para as pesquisas do primeiro grupo, encontramos a suicidologia, que descreve e articula a tríptica suicidária: ideação suicida (IS), tentativa de suicídio (TS) e suicídio (S). Este campo de estudo costuma agrupar sobre o termo "condutas suicidárias" comportamentos diversos como os três já citados, assim como as automutilações, de forma a criar uma confusão e um contínuo entre os termos destacados. De acordo com De Luca, Bonnichon e Marty (2012), há uma frequente associação, principalmente entre as automutilações e as tentativas de suicídio, que teria como base os trabalhos médico-psicológicos de Moron sobre o modelo da crise suicidária na déc. 1970. Neste modelo, a ideia de um contínuo faz com que ambos pareçam equivalentes, uma vez que feridas autoinfligidas são automaticamente entendidas como consequência de uma ideação suicida e/ou como tentativas diretas de suicídio.

Contudo, apesar de encontrarmos vínculo estreito e concomitância entre ambos, é importante compreendermos que cada um desses atos tem uma especificidade, por mais que compartilhem como base comum estarem inseridos no grupo dos comportamentos autodestrutivos. Dessa forma, ao nos aproximarmos do segundo grupo de autores que defendem a existência de uma diferença de ordem qualitativa entre automutilação e tentativa de suicídio, podemos pensar que são fenômenos com naturezas distintas. Ambos se diferenciariam pela intencionalidade, letalidade, cronicidade, métodos, cognições, reações durante e depois do ato, descrições sociodemográficas e prevalência (Muehlenkamp, 2005). 
Ainda nesta direção, Gicquel e Corcos (2011) sublinham que existem diversos pontos de diferença entre ambos os comportamentos, mas destacam a intencionalidade do ato. Os autores chamam a atenção para o fato de eles terem objetivos finais bastante diferentes: enquanto, no suicídio, o fim buscado é a morte, o alívio alcançado com a morte do corpo, as automutilações visariam modificar a situação que se tornou insuportável ainda em vida. Apesar da comorbidade entre automutilação e a tríptica suicidária ser alta, pesquisas apontam para o fato de que sujeitos com histórico de tentativas de suicídio tendem a ter menos episódios de TS enquanto estão envolvidos com comportamentos automutilatórios (Gratz, 2003).

Destacamos o fato de a própria definição do fenômeno já excluir a dimensão do suicídio, uma vez que aponta para um ato autodestrutivo sem intenção consciente de morte. Por mais que o sujeito tenha intencionalidade inconsciente de morte, o ato automutilador não vai levá-lo a esse fim, e isso, por si só, já marca uma diferença entre os atos.

Pommerau, Brun e Moutte (2009) também observam o que chamaram de função antissuicídio presente nas automutilações. Os autores apontam como características dessa função o recurso a uma ação sensório-motora que permite não só uma sensação de alívio frente à tensão acumulada, descarga de acúmulo pulsional, mas também, e, principalmente, a existência de um limite físico (delineado pelas feridas) que contenha e impeça a autodestruição total. Na mesma direção, Corcos e Richard (2006) entendem a automutilação como tentativa radical de impedir uma ameaça depressiva grave que poderia levar ao suicídio. Os autores sugerem o conceito de melancolia abortada para se referir à diferença entre ambos os comportamentos: enquanto o suicida volta seus esforços para dar fim à própria vida, tendo como alvo o corpo como um todo, o sujeito que se automutila encontra nesta prática um direcionamento desta agressividade para partes de si e, consequentemente, um grau de proteção contra a morte.

O próprio Freud (1901/1996c) faz alusão aos comportamentos automutilatórios diferenciando-os do suicídio, mesmo reconhecendo que há momentos em que ambas as intenções podem aparecer concomitantemente. $\mathrm{O}$ autor relaciona estes quadros aos casos mais graves de neurose e, apesar de não se aprofundar na temática das automutilações, ele classifica este fenômeno como parte dos atos casuais. Estes seriam atos que trazem prejuízos para o sujeito, 
contendo uma motivação inconsciente, no entanto, seriam munidos, também, de uma intenção consciente e deliberada. Nos casos descritos, Freud (1901/1996c) narra supostos "acidentes" nos quais ele acredita ter havido uma intenção consciente (e inconsciente) de se machucar e faz uma ligação entre esta motivação e um caráter punitivo do ato em questão:

Sei agora e posso provar com exemplos convincentes que muitos ferimentos aparentemente acidentais sofridos por esses doentes são, na realidade, lesões autoinfligidas. Acontece que uma tendência à autopunição, que está constantemente à espreita e comumente se expressa na autocensura ou contribui para a formação do sintoma, tira hábil partido de uma situação externa oferecida pelo acaso, ou contribui para sua criação até que se dê o efeito lesivo desejado. (p.182)

Para além desta descrição, Freud (1901/1996c) aponta ainda para uma problemática já apresentada no terreno das automutilações: a autodestruição como campo ampliado. Mesmo sem possuir ainda o conceito de pulsão de morte, o autor aponta para uma tendência à autodestruição que está presente na grande maioria das pessoas, mesmo dentre aquelas que não vão pôr em prática nenhuma conduta autolesiva. Ele diz que tal conduta não é rara, ao contrário, e que a automutilação pode ser compreendida como um compromisso entre este movimento de destruição e outras forças que se opõem a ele.

Nos escritos de Menninger (1938/1970), que também era psicanalista, encontramos os primórdios de uma discussão que leva em conta o segundo dualismo pulsional freudiano. $\mathrm{O}$ autor compreende os diferentes tipos de autodestruição como formações de compromisso existentes entre a pulsão de morte e as pulsões de vida, com o intuito de evitar o suicídio propriamente dito. O objetivo final seria o de manter a pessoa viva, mesmo que, para isso, ela precise lesionar-se a si mesma. Ao propor o conceito de suicídio focal, anteriormente descrito, o autor afirma haver nas automutilações uma dimensão de proteção contra o suicídio propriamente dito, uma vez que o impulso de morte estaria voltado para apenas uma parte do corpo do sujeito.

Com base nas ideias de Menninger, Suyemoto (1998) propõe o modelo antissuicídio como um dos pilares que auxiliariam a compreender as funções da automutilação. Este modelo também se apoia na teoria pulsional freudiana e aponta para uma espécie de acordo entre pulsões de vida e pulsão de morte, tendo como objetivo final evitar a completa destruição do indivíduo, canalizando esses impulsos destrutivos para o ato de se automutilar. 
Em direção similar à Menninger e Suyemoto, Firestone e Seiden (1990) descrevem como "microssuicídios" uma série de comportamentos autodestrutivos, dentre os quais as automutilações, que surgem como formas de lidar com dificuldades advindas de perdas (reais ou imaginárias) e do não controle sobre a inevitabilidade da morte como destino do ser humano. Os autores chamam a atenção para o fato de estes comportamentos estarem muito mais disseminados em nossa sociedade do que nos permitimos observar e traçam uma relação direta entre essa espécie de negação e uma dificuldade atual em lidar com sintomas que provoquem prejuízo físico, especialmente aqueles causados pela própria pessoa.

Retomando a ideia de Menninger (1938/1970) sobre o suicídio focal, podemos refletir acerca do que o autor chama de "autodestruição autopreservadora" (p. 21). O autor dá o exemplo de roedores que, ao ficarem presos em armadilhas, roem a própria pata com o intuito de se libertarem. Haveria, nesses casos, o intuito deliberado de se fazer mal dentro de uma situação específica com objetivos bastante claros: ferir uma parte de seu próprio corpo para a proteção da vida como um todo. De acordo com o autor, o mesmo objetivo de sobrevivência estaria presente nas situações de automutilação. Podemos aproximar este pensamento de Menninger do conceito ferencziano de autotomia.

Conforme apontam Câmara e Canavêz (2019), Ferenczi traz algumas contribuições que podem nos auxiliar a compreender os fenômenos de automutilação, especialmente no que diz respeito a seus estudos sobre o tique e as estereotipias. Em 1921, no artigo intitulado Reflexões psicanalíticas sobre os tiques, Ferenczi apresenta sua compreensão destes fenômenos. Os tiques teriam natureza diferenciada dos demais sintomas neuróticos, apresentando uma natureza orgânica e narcísica. De forma bastante resumida, podemos dizer que os portadores de tiques neuropáticos teriam desenvolvido hipersensibilidade a alguma excitação excessiva anterior e se defenderiam através de uma descarga motora. Esta hiperestesia seria expressão do narcisismo, demonstrando apego da libido a alguma parte privilegiada do corpo, de modo que os tiques surgiriam como consequência de traumatismos somáticos.

Exemplificando, o sujeito poderia ter sofrido uma conjuntivite severa em algum momento da vida e, posteriormente, desenvolveria um tique de espasmos da pálpebra. Mesmo que o trauma seja produzido pela lesão orgânica, ele deixa uma memória patogênica que se apresenta no corpo, e é essa espécie de 
"lembrança" que continua fornecendo a percepção interna de uma excitação desagradável no órgão, mesmo que a lesão já não exista mais. Diante do sofrimento causado pela continuidade de excitação desagradável no órgão antes lesado, Ferenczi (1921/2011a) afirma que uma das formas de se livrar dessa excitação é a descarga motora, presente nos tiques, e que esta descarga pode aparecer em diferentes modalidades para lidar com o sofrimento. Uma destas modalidades é o voltar-se para a própria pessoa, que se caracteriza pelos tiques de coçar, de se infligir uma dor e pela tendência à automutilação. Ferir a si mesmo também se caracteriza como uma forma de descarga motora, recurso utilizado por estes pacientes.

É dentro desta modalidade defensiva que Ferenczi (1921/2011a) traça uma analogia entre os comportamentos de autolesão e o conceito de autotomia. Este conceito é emprestado por Ferenczi (1924/2011b) da Zoologia e desenvolvido a partir da observação de animais que desprendem do próprio corpo órgãos ou partes que estejam submetidos a uma irritação excessiva ou que causem algum tipo de dor ou prejuízo. Alguns animais se dividem em partes menores, ou podem arrancar um membro doloroso a dentadas. Outros, com o intuito de fugir de um perigo mortal, livram-se de um pedaço de si para conseguirem escapar.

Um exemplo amplamente citado é o da lagartixa, que abandona sua cauda ao se sentir ameaçada, separando-se desta para conseguir fugir e ficar a salvo. Tendo a Zoologia como base, o autor expande o conceito de autotomia ao dizer que este movimento faz parte de todo ser vivo, caracterizando-se como uma tendência na direção da vida. Pensar a lógica da autotomia estando relacionada aos fenômenos de automutilação é pensar que haveria, nestas práticas, uma espécie de "sacrifício" de uma parte do corpo, em especial, da pele, que é lesionada, com o intuito de preservar o todo.

Essa discussão apresentada abre espaço para pensarmos na dimensão de paradoxo existente nos atos de automutilação. Em consonância com Dargent e Matha (2011), acreditamos se tratar de um fenômeno que comporta, ao mesmo tempo, duas dimensões aparentemente contrárias: se, por um lado, podemos entendê-lo como efeito e destino de uma destrutividade que se volta para o próprio corpo, por outro lado, podemos também compreendê-lo como um ato a serviço da vida, uma vez que preserva a existência do sujeito. Dessa forma, pulsão de morte e pulsões de vida encontram-se entrelaçadas e costuradas por uma 
precária amarração que permite alguma saída, mesmo que radical, frente a um sofrimento psíquico que pode levar à decisão de encerrar a própria vida.

No que diz respeito às saídas encontradas diante deste excesso, encontramos na Psicanálise algumas soluções propostas. Esse campo de saber, de maneira geral, vai remeter a automutilação à questão corporal. A Psicanálise compreende estas práticas como uma modalidade específica de descarga da excitação via ato, via corpo, nos quais a questão do traumático assume papel preponderante. Dentro do campo das patologias do ato, há uma sobreposição entre o tema da automutilação e o período da adolescência, uma vez que este é o tempo de aparecimento de torrentes pulsionais e emocionais que vão abalar as bases narcísicas e edípicas do psiquismo do sujeito, conforme veremos no capítulo a seguir. 


\title{
2 \\ A problemática do corpo na automutilação
}

\author{
Parece teimosia. Mas é o corpo que não para de \\ emitir mensagens, como um velho sobrevivente feito de \\ carne, na grande máquina de produzir imagens e espetáculos.
}

Leusa Araujo

No capítulo anterior, buscamos construir um panorama sobre a automutilação com o objetivo de complexificar o fenômeno e demonstrar a variedade de práticas que compõem este cenário. Partindo das diferentes definições e estudos existentes na literatura sobre o fenômeno, chegamos ao entendimento de que a automutilação se constitui como uma série de condutas diferenciadas que tem em comum os danos infligidos ao próprio corpo, em especial, à própria pele. Dessa forma, podemos sublinhar que o terreno das automutilações deixa em evidência o registro do corpo. A Psicanálise é um campo de saber que, de maneira geral, remete a automutilação à questão corporal e esta forma de pensar o fenômeno será de grande importância no presente capítulo.

Nesta direção, podemos nos perguntar acerca do corpo da automutilação, que surge como lugar privilegiado de sofrimento autoinfligido. Que papel o corpo desempenha nos fenômenos automutilatórios? Podemos compreender esta convocação do corpo para lidar com um excesso pulsional que não encontra saídas diferenciadas? Se apostarmos na ideia de que os fenômenos automutilatórios, apesar de causarem dor e sofrimento, também constituem o sujeito, em sua maneira mais primitiva de ser, o que nos comunicam essas "autoferidas"? De que forma este corpo que é convocado auxilia estes sujeitos a se manterem vivos, a sentirem que existem e são contínuos ao longo do tempo e do espaço?

A importância atribuída ao corpo como local privilegiado de sofrimento traz um ponto de contato importante na Psicanálise entre os fenômenos automutilatórios e o período da adolescência, momento de prevalência de aparição destas práticas. Há afinidades entre ambos, uma vez que tanto na automutilação quanto na adolescência o corpo toma a frente da cena, abrindo espaço para descargas da excitação via ato. Na adolescência, este é o tempo de aparecimento de torrentes pulsionais e emocionais que vão abalar as bases narcísicas e edípicas 
do psiquismo do sujeito, exigindo uma série de ressignificações importantes. $\mathrm{Na}$ automutilação, o ego do sujeito também se encontra ameaçado, tendo como resposta radical o recurso ao corpo e ao ato.

\section{1 \\ Automutilação na clínica psicanalítica: a prevalência da adolescência}

Diversos autores que trabalham o tema das automutilações em Psicanálise vão atentar para a dimensão privilegiada que ganha o corpo nesses fenômenos. É o corpo que manifesta um sofrimento que não pode ser colocado em palavras e através do qual o sujeito encontra uma via de expressão e de descarga daquilo que o faz sofrer. No cenário das autoferidas, é o corpo que está à frente. Ele denuncia conteúdos e vivências que ultrapassam o universo das representações psíquicas e que apontam para outras formas de aparição dessas excitações que não estão contidas de forma representacional. A convocação ao corpo aponta para o irrepresentável de um excesso pulsional que não pôde ser contido e que ultrapassou os limites psíquicos daquele sujeito.

Tanto Corcos e Richard (2006) quanto Dargent e Matha (2011) afirmam que a automutilação nos dá notícias de uma falha no sistema de paraexcitação, baseado nas discussões teóricas advindas do segundo dualismo pulsional de Freud (1920/1996g), em especial acerca do modelo da vesícula. Este modelo consiste em uma espécie de dispositivo protetor antiestímulo, nos protegendo contra possíveis excitações recebidas, reduzindo suas intensidades. No entanto, quando o aumento da excitação é maior do que a capacidade de proteção da vesícula, ela acaba sendo rompida, veiculando um excesso pulsional que transborda as possibilidades psíquicas de representação.

Com isso, compreendemos que, dentro das condutas de automutilação, o que está em jogo é um corpo para além da representação, que sofre com uma carga pulsional excessiva. Nesse contexto, Dargent (2010) sublinha que “o corpo é, acima de tudo, atacado" (p. 132, tradução nossa), e este ataque nos dá notícias do transbordamento pulsional que excede as possibilidades psíquicas do sujeito. Diante da ameaça de irrupção de um excesso pulsional e do fracasso do princípio do prazer, coloca Cardoso (2001), outras formas de ação serão necessárias para dar conta desse montante. Será preciso fazer algo diante disso que excede, tentar 
dominar o que não se apresenta pela via da palavra. É nesse contexto que a tendência à ação surge como possibilidade de saída diante do impasse gerado pelo excesso: o agir passa a tomar conta da cena.

Mayer (2001) aponta que o campo da atuação diz respeito a um "curtocircuito" existente entre o impulso e a ação, não havendo espaço para o processamento psíquico. $\mathrm{O}$ autor destaca como características fundamentais destas ações seu caráter impulsivo, repetitivo e atual. Complementando, Savietto (2007) aponta que o fenômeno das passagens ao ato gera uma tendência do aparelho psíquico a responder ao excesso de excitação utilizando o recurso da compulsão à repetição, na tentativa de manter seu equilíbrio. A autora sublinha as passagens ao ato como uma tentativa de contenção do excesso pulsional sem que se efetive um trabalho de elaboração psíquica.

Nesse sentido, podemos compreender que, na passagem ao ato, há uma impossibilidade de o sujeito recorrer à palavra, lançando mão do corpo como principal via de descarga do excesso pulsional que o atormenta. A dimensão que o faria recorrer à fala está fora de seu alcance. Dentro de uma infinidade de atos, pode-se pensar na automutilação como uma das resultantes de um encontro com esse excesso pulsional que o aparelho psíquico não é capaz de suportar e elaborar. Dessa forma, o ato automutilatório constituir-se-ia como uma possibilidade de descarga para o sujeito em questão, assim como uma tentativa de contenção desse excesso pulsional que transborda.

Diversos estudos apontam para a adolescência como o momento de surgimento dos comportamentos automutilatórios (Favazza, 1987/2011; Pattison \& Kahan, 1983, Suyemoto \& Macdonald, 1995; Richard, 2005; Gicquel e Corcos, 2011). Esse fenômeno vem crescendo na população adolescente a partir das décadas de 1960 e 1970, e pesquisadores de diferentes países vêm se engajando em estudos que possam esclarecer os motivos para este crescimento, assim como auxiliar na compreensão destas práticas. No Brasil, podemos observar um aumento significativo destas práticas nos últimos vinte anos (Giusti, 2013). Nessa direção, a temática da automutilação começa a aparecer com mais frequência nas escolas, nas unidades de saúde e nos consultórios particulares.

Atualmente, a maior parte dos estudos encontrados na literatura psicanalítica sobre automutilação diz respeito ao momento da adolescência, uma vez que é neste período que encontramos a maior prevalência desse fenômeno. 
Assim como na automutilação, a adolescência traz à tona a prevalência do corpo e do ato como vias de descarga e de acesso a vivências que não conseguem ser elaboradas psiquicamente. A clínica da adolescência vai de encontro à clínica da automutilação, uma vez que ambas compartilham problemáticas em comum, dentre as quais o corpo está em evidência. Deste modo, para melhor compreender o fenômeno das automutilações, a problemática da adolescência constitui um eixo fundamental para sustentar nossa argumentação.

Com o surgimento da puberdade, uma série de mudanças vão se impor ao sujeito, dentre as quais destacamos mudanças nos âmbitos corporal, sexual, social e familiar. Trata-se de um período marcado por perdas, lutos e ressignificações de elementos infantis importantes, uma vez que o sujeito passa a ter acesso a um universo novo e é convocado a lidar com uma série de problemáticas que não se impunham a ele na infância. Podemos compreender este período como um processo que exige um trabalho constante de nomear, conter e dar sentido a toda novidade que é vivenciada. Tudo isso leva à ameaça subjetiva de um risco de perda da integridade egoica ligada a essa série de remanejamentos que o sujeito vai ser impelido a viver. Nesse sentido, a automutilação pode ser entendida como um dos recursos radicais utilizados como forma defensiva frente às ameaças de desintegração do eu.

Em relação às ressignificações corporais e psíquicas próprias do momento da adolescência, podemos pensar, em consonância com Barrault (2005), que o recurso ao corpo torna-se um meio privilegiado de expressão na adolescência e, dessa forma, o início das condutas automutilatórias estaria vinculado a essa problemática. Nesse cenário, aponta Birraux (1994/2013), o inimigo passa a ser o corpo, uma vez que este condensa tanto a memória da infância quanto as novas necessidades e exigências de um corpo que agora pode se realizar sexualmente. $\mathrm{O}$ corpo na adolescência não é apenas uma realidade biológica, e sim um paradigma essencial para compreender a maior parte das problemáticas deste período. Ele é o pano de fundo sobre o qual os remanejamentos não só físicos, mas também eróticos e fantasmáticos, possam se dar (Marty, 2010).

Encontramos em Demantova (2017) uma estreita relação entre os elementos traumáticos que constituem o momento da adolescência e as escarificações como recurso defensivo e de simbolização frente a esta problemática. Dentro dos processos de separação próprios à adolescência, a autora 
ressalta o luto dos objetos primários. Esta é considerada a operação mais complexa de separação, sendo vivida pelo adolescente como uma espécie de morte, sentida como uma real experiência subjetiva de perda. A dificuldade se acentua uma vez que o objeto que precisa ser abandonado é justamente aquele que fundou o sujeito narcisicamente.

Contudo, Cardoso (2014) chama atenção para o caráter paradoxal presente no processo de separação próprio à adolescência e afirma que, em alguns casos, a maior dificuldade está em se separar de um objeto que esteve ausente, uma vez que isso potencializaria a sua presença. Em alguns casos, esta operação de separação não pode se completar de forma satisfatória, uma vez que a relação com os objetos primários tenha se configurado de forma complicada desde os primórdios da constituição psíquica. Nesses casos, Demantova (2017) destaca que a separação dos objetos primários na adolescência pode levar a uma verdadeira desorganização narcísica, motivo pelo qual os adolescentes acionariam o recurso do ato, convocando o corpo para dar conta de uma problemática que o ego não consegue resolver psiquicamente. As automutilações entrariam em jogo aqui como forma de proteção diante da ameaça de perda, tanto de si como do outro.

Todas estas transformações da adolescência, acrescidas pela revivescência do complexo de Édipo, deixam o jovem com um sentimento de ser transbordado por questões que se impõem a ele sem que tenham algum domínio sobre elas. Cardoso $(2001 ; 2006)$ se refere à adolescência como um momento de travessia, ressaltando a prevalência de mecanismos defensivos mais arcaicos e elementares, tais como as atuações e passagens ao ato, fruto de um apelo extremo do ego para que o corpo entre em cena. Este fato nos dá notícias de um nível precário de elaboração psíquica que acompanharia esses jovens e os levaria a respostas radicais, tais como o recurso ao ato automutilatório.

O sujeito se sente submetido a essa série de mudanças e é reenviado a uma situação de passividade, que vem fazer eco com um sentimento de passividade extrema pertencente à primeira infância. Frente a tudo isso, Barrault (2005) aponta que o adolescente vai tentar se opor, buscando forças através do recurso ao ato, de forma que, nos esclarece Demantova (2017), o apelo ao ato se inscreve em um cenário defensivo, como último recurso frente à experiência insuportável de passividade e impotência. 
$\mathrm{Na}$ mesma direção, encontramos nas condutas de automutilação uma tentativa de dominar ativamente, através da agressividade voltada para o próprio corpo, alguma vivência de passividade anterior a qual o sujeito teria sido submetido. Corcos e Richard (2006), assim como Pommereau (2006a), apontam para esta característica da automutilação como tentativa de retomar uma posição ativa. Dargent e Matha (2011) ressaltam a característica reflexiva presente nas condutas automutilatórias: o sujeito é, ao mesmo tempo, ativo (quando se inflige as feridas) e passivo (vive na própria pele os machucados). Ele é a vítima e seu próprio carrasco.

As autoras relacionam o fenômeno das automutilações com os destinos pulsionais que aí se encontram envolvidos. Se, por um lado, podemos considerar, na tentativa de inversão da passividade em atividade, presente nas atuações, o destino pulsional da reversão em seu oposto, encontramos entrelaçado a ele o destino pulsional do retorno ao próprio eu, uma vez que o objeto não chega a ser solicitado, sendo um ato que se resolve pela própria pessoa e no próprio corpo. Temos, nesse cenário, os dois destinos pulsionais mais primitivos, anteriores ao mecanismo de recalcamento (Freud, 1915/1996f).

É neste cenário que observamos de que forma as mudanças advindas a partir da puberdade perturbam de forma grave o equilíbrio narcísico conquistado na infância, colocando em perigo a coesão do eu e o sentimento de continuidade de existência, como sinaliza Marty (2007). Se o corpo da infância tornou-se familiar e bem mapeado, o corpo da adolescência surge como uma surpresa e um mistério a ser desvendado. Dessa forma, Marty (2010) aponta que as mudanças que surgem na adolescência, tanto no universo somático quando no psíquico, colocam em cena um vivido de descontinuidade que se manifesta através de sentimentos de estranheza e não reconhecimento de si mesmo. Nesse sentido, podemos compreender que a passagem da infância para a vida adulta não se dá sem rupturas, descontinuidades que também fazem parte dessa travessia, tecendo e costurando o sentimento de continuidade de ser.

Gostaríamos de ressaltar que a automutilação comporta sempre duas dimensões: uma dimensão edípica, contendo relação direta com a problemática da adolescência e seus remanejamentos e revivescências, e uma dimensão arcaica, que diz respeito a problemáticas mais narcísicas do início da vida, de construção do eu-corporal e da dimensão do sensorial. 
Se, ao pensarmos na adolescência, estamos em contato direto com as questões edípicas trazidas por todo o trabalho psíquico exigido pelo período, não nos deixemos esquecer que o arcaico se mantém e se presentifica em diferentes momentos de nossa existência. Aproveitando a discussão acerca da temporalidade na qual se inscreve a adolescência, que não se caracteriza como desenvolvimento linear de etapas a serem cumpridas e ultrapassadas, mas como momento de passagem que, ao mesmo tempo, mantém vivências de continuidade e de descontinuidade com outros tempos da infância, a adolescência ganha um novo olhar de importância ao longo de toda a vida do sujeito.

Em consonância com Gicquel e Corcos (2011), podemos pensar que as automutilações encontradas na adolescência falam de um sofrimento psíquico que é anterior a esse momento, mas que está sendo ressignificado junto com o trabalho da adolescência. Os autores destacam a importância de pensarmos na qualidade do desenvolvimento infantil deste adolescente, assim como em suas memórias mais antigas, uma vez que a puberdade traz à tona uma reativação de eventos, sentimentos e sensações da primeira infância.

Nesta direção, Roussillon (2010a) ressalta que a adolescência é um tempo no qual o sujeito teria uma espécie de "segunda chance" potencial para ressignificar processos que começaram nos primórdios de sua vida psíquica, em especial aqueles que não se passaram bem em relação ao par mãe-bebê. No cenário das automutilações, Gicquel e Corcos (2011) apontam para um processo de construção de si mesmo que é contínuo no tempo e espaço desde os primeiros anos de vida, sendo a adolescência um momento de ressignificação importante, de construção de novas formas de ser e estar no mundo.

Esse pensamento vai de encontro aos estudos recentes da psicanálise francesa sobre possíveis pontos de convergência entre o funcionamento psíquico dos bebês e dos adolescentes: movimento chamado Bébés-ados (Braconnier \& Golse, 2008). Sobre esta temática, Konicheckis (1999) ressalta que os vínculos psique-soma seriam fundadores e originais desses dois momentos da vida, se caracterizando como fio condutor que permite o diálogo entre ambas as problemáticas. Complementando, Roussillon (2011) e Moro (2008) ressaltam a importância das expressões somáticas como protonarrativas de si, sendo o corpo uma via de expressão privilegiada, especialmente nos momentos da primeira infância (pré-verbal) e da adolescência. 
A partir desse campo de estudos Bébés-ados, encontramos uma convergência entre dois momentos primordiais na constituição psíquica e nos processos identificatórios, de forma que a importância em reconhecer a dimensão do arcaico no fenômeno das automutilações surge como elemento de bastante interesse para o presente trabalho. Compreender as manifestações da automutilação na adolescência também nos dá notícias da constituição psíquica desse sujeito, tendo relação direta com o bebê que esse adolescente um dia foi e com mecanismos e formas primitivas do eu que permanecem ao longo do tempo.

Apesar de não citarem explicitamente o quadro clínico das automutilações, Golse e Roussillon (2010) defendem a ideia de que fenômenos clínicos que passam pelo corpo ou pelo ato são testemunhas de um arcaico ainda vivo e sempre atuante na vida psíquica dos sujeitos. Apesar de esta dimensão estar mais explicitada em quadros traumáticos ou psicopatologias futuras, os autores compartilham a visão de que elementos deste arcaico estariam na base de nosso funcionamento psíquico e se fariam presentes ao longo de toda a vida, não importando a idade que tenhamos. Ambos voltam sua atenção para a importância das primeiras experiências subjetivas na constituição psíquica e ressaltam que o próprio Freud já deixou esse pensamento encaminhado ao longo de sua obra, apesar de não ter se aprofundado sobre a mesma ótica.

Aprofundando a temática, Roussillon (2010b) aposta na importância de voltarmos nossa atenção para os primórdios da constituição psíquica, uma vez que neste primeiro tempo estariam contidas experiências que podem nos auxiliar a melhor compreender sofrimentos que vão eclodir em segundos, terceiros e "enésimos" tempos. No caso das automutilações, a adolescência e seu "segundo tempo" carregaria consigo elementos advindos de um tempo primevo, que surgiriam na tentativa de se ressignificar essas experiências arcaicas junto com outras problemáticas próprias à idade. A vida adulta e seus "enésimos tempos" também poderiam exemplificar eclosões de sofrimentos que teriam tido suas primeiras camadas delineadas em outros tempos, fazendo eco com as camadas da primeira infância, da adolescência e até mesmo da própria vida adulta.

Na mesma direção, Albert Ciccone $(2011 ; 2012)$ defende a ideia de que a forma de apreensão do mundo e as marcas deixadas pela nossa experiência enquanto bebês não desaparecem nem se transformam completamente com o passar do tempo, na direção da vida adulta. A maneira de se relacionar com o 
mundo permanece lado a lado com outras maneiras de compreensão de si mesmo e dos outros, de forma que há uma dimensão do arcaico presente no infantil que será sempre atual e atuante em nós.

No que diz respeito à problemática das automutilações, Ciccone (2011) as apresenta como uma via atual através da qual algumas vivências do arcaico se apresentariam, em um registro que conjuga ao mesmo tempo passado e presente. Esta forma de compreensão do arcaico coloca em jogo um curto-circuito no tempo: experiências precoces produzem efeitos no desenvolvimento de todo sujeito, de modo que não se tratam de experiências estanques, com começo, meio e fim, mas de formas de se relacionar e de estar no mundo que se encontram presentes ao longo de toda a vida.

Essa forma de compreender os primórdios não evoca apenas uma época específica no tempo, mas corresponde à maneira através da qual o infantil, sempre vivo e atuante em nós, vê o mundo, interpreta as experiências, sofre e tenta se proteger de novos sofrimentos. Considerar que as experiências precoces estão na base dos sofrimentos humanos e do desamparo é pensar que o infantil não pertence apenas à história passada do sujeito, mas ao presente, tendo efeitos que não se encontram presos ao tempo do passado, mas dizem respeito à história presente do sujeito (Ciccone, 2011).

Com o intuito de trazer à tona uma discussão sobre a temporalidade dentro dos estudos sobre a primeira infância, Golse e Roussillon (2010) tomam emprestado uma contribuição de Jean Laplanche a respeito de uma temporalidade que não é nem a da seta, direcionada apenas para o futuro, e nem a do círculo, culminando nos mesmos acontecimentos: uma ideia de tempo em espiral. Essa forma de compreender o tempo dá notícias dos mesmos acontecimentos ou tipos de experiências subjetivas, porém já contendo um plano distanciado do primeiro, com elementos novos e antigos ao mesmo tempo.

Nesta direção, conjugarmos o estudo da adolescência e da primeira infância com o intuito de melhor compreendermos como o campo das automutilações possui relação direta com a complexificação da discussão sobre a temporalidade na constituição psíquica. Se o tempo não é entendido linearmente, mas como espiral de eterno retorno, os acontecimentos da vida atual fazem eco e ativam camadas mais antigas, que permanecem atuais pelo próprio movimento temporal complexo. O passado deixa de ser estanque e abrimos caminho para uma 
compreensão da dimensão arcaica presente no fenômeno das automutilações. Roussillon (2010b) define o arcaico como "um tempo além do tempo" (p. 98, tradução nossa) e, se pensarmos em movimentos espiralados formados pelas experiências (que constituem e/ou assolam o psiquismo), estaremos sempre diante de um tempo que é inalcançável - um tempo para além de seu próprio tempo.

Dessa forma, o presente trabalho volta seu interesse para uma dimensão mais arcaica do fenômeno das automutilações, na direção de compreender possíveis efeitos da constituição psíquica que estariam presentes nas condutas automutilatórias, para além dos sofrimentos traumáticos que podem estar sendo reencenados em busca de simbolização. Apostamos na ideia de que as automutilações nos dão notícias de um universo sensorial e de níveis mais primários de representação do eu desse sujeito, que permanecem atuando, assim como de seus primeiros encontros intersubjetivos e relacionais com seus objetos primordiais, trazendo o corpo para o centro da cena.

\section{2 \\ O corpo e o pré-verbal na automutilação}

Se, na adolescência, encontramos uma exigência de trabalho psíquico com o intuito de ressignificar o corpo e o sexual que surgem com uma novidade, nos deparamos ainda com uma revivescência do Édipo, trazendo à tona todas as questões complexas que envolvem a escolha objetal e ainda a consolidação dos processos identitários. Contudo, ressaltamos anteriormente que o período da adolescência traz consigo a ressignificação de processos primários e secundários. $\mathrm{O}$ universo das vivências anteriores à aquisição de linguagem verbal, compartilhado entre o par mãe-bebê, encontra-se em foco quando o corpo está à frente da cena, mais ainda se falamos sobre práticas que envolvem a pele.

É nesse sentido que acreditamos ser de extrema importância voltar nossas atenções para a dimensão pré-verbal no universo das automutilações. Se esse fenômeno se ancora no corpo, tudo que se passa nessa seara ganha um peso diferenciado. Sabemos que antes de sermos capazes de nos representarmos psiquicamente, o eu existe no e através do corpo. O corpo vem antes da palavra, das representações e dos pensamentos. Começamos a existir pelo corpo e a dimensão corporal nos constitui e nos acompanha ao longo de toda a vida. 
Ao abordarmos as dimensões de mente e corpo, gostaríamos de ressaltar que não estamos defendendo uma visão hierárquica na qual a atividade psíquica teria um valor maior do que elementos advindos do corpo, ou que a elaboração psíquica é almejada em detrimento de outros recursos corporais. As dimensões do soma e da psique são parte de um só sujeito - de forma que optamos por apenas ressaltar as diferenças existentes entre esses dois registros. Corpo e mente formam um só eu, mas se desenvolvem e se expressam de formas diferenciadas.

Seguindo as contribuições freudianas sobre a temática em questão, gostaríamos de trazer à tona o conceito de eu-corporal e ressaltar o fato de que o ego não está formado desde o princípio da vida, como afirma Freud (1914/1996e) em seus estudos sobre o narcisismo. Nas palavras do autor (p. 84), "estamos destinados a supor que uma unidade comparável ao ego não pode existir no indivíduo desde o começo; o ego tem que ser desenvolvido". Será necessário o surgimento de certa "ação psíquica", que promova o surgimento do narcisismo, para que o sujeito possa se reconhecer como ele mesmo, habitante daquele corpo e daquele psiquismo. Entretanto, se o ego não está lá desde o princípio, como ele se origina?

Em $O$ ego e o id, encontramos a clássica frase que dá sustentação à maioria das pesquisas atuais sobre o corpo e o início da vida em Psicanálise: “O ego é, primeiro e acima de tudo, um ego corporal; não é simplesmente uma entidade de superfície, mas é, ele próprio, a projeção de uma superfície" (Freud, 1923/1996h, p. 39). Sendo assim, compreendemos que a origem do ego será no corpo. Se no início tudo era id, a partir do contato com o mundo externo - tendo como mediadores a percepção e os órgãos dos sentidos - uma parte do id vai se diferenciando até formar o ego (e posteriormente o superego).

Gostaríamos de ressaltar ainda uma nota de rodapé anexada pelo autor em 1927:

Isto é, o ego em última análise deriva das sensações corporais, principalmente das que se originam da superfície do corpo. Ele pode ser assim encarado como uma projeção mental da superfície do corpo, além de, como vimos acima, representar as superfícies do aparelho mental. (Freud, 1923/1996h, p. 39)

Dessa forma, sublinhamos que a vida começa pelo corpo e pelas sensações com as quais entramos em contato e destacamos a importância que Freud dá à superfície da pele, considerando que o ego surge a partir do contato que temos 
com o mundo, mediados pelas sensações corporais. É a partir da percepção e da consciência, da maneira como sentimos e somos transformados pela nossa experiência sensorial com o mundo, que o ego se forma - e se transforma. A importância da pele na origem do eu será de suma importância para nossos questionamentos e melhor descrito no próximo tópico deste trabalho.

De acordo com Corcos (2009/2013) e Dargent e Matha (2011), a automutilação surge em um cenário onde o acesso ao pensamento está prejudicado, de forma que o corpo é quem toma a frente da cena e faz o papel de paraexcitação. Ela se caracterizaria como um comportamento de externalizar no corpo uma dor psíquica pouco circunscrita e seria uma tentativa de conter e filtrar esse excesso pulsional. É um ato de descarga que gera um alívio imediato e passageiro.

O psiquismo é afetado face ao terror do excesso pulsional, de forma que a emoção que provém do corpo não consegue tomar a forma de pensamentos. Esse fenômeno materializa e manifesta um sofrimento psíquico que não consegue ser colocado em palavras ou encontrar uma via de expressão simbólica que não seja através do corpo. É um sofrimento no qual o sujeito não sabe exatamente do que se trata, uma vez que o sofrimento não está inserido em uma cadeia representacional.

Baseado nas contribuições de Bion, Corcos e Richard (2006) evocam a ideia de que o corpo é a fonte das emoções e dos pensamentos, reiterando a ideia que determinados sofrimentos não são representados psiquicamente. No que diz respeito à automutilação, estes autores relacionam esse fenômeno com a alexitimia, que seria uma dificuldade em descrever verbalmente emoções, sentimentos e sensações corporais vividos. Nesse cenário, a automutilação teria como função uma tentativa de regular as emoções, que não conseguem ser traduzidas pelo sujeito em palavras. O que acaba jorrando para o corpo e termina como ato automutilatório seriam emoções às quais o sujeito não teria acesso verbalmente, tornando-as indizíveis, impossíveis de se colocar em palavras.

Se, na primeira infância, a emoção é transmitida através do corpo entre o par mãe-bebê, a linguagem corporal passa a desempenhar um papel fundamental na construção das emoções do bebê. Se essa transmissão não é realizada de forma satisfatória, o bebê não consegue entender suas próprias emoções, de forma que elas ficam bloqueadas e restritas ao corpo. Essas feridas não são passíveis de fala, 
uma vez que dizem respeito a formas de experimentar o mundo e situações anteriores à aquisição da linguagem verbal.

De acordo com Pommereau (2006b), as automutilações são indícios de uma linguagem do indizível, associando-se a elas uma função de comunicação. Essa função consiste em encarnar - tornar carne - as feridas psíquicas do sujeito, direcionando-as ao corpo e à possibilidade do olhar do outro. As feridas físicas lhes instauram a esperança de serem vistos, reconhecidos e compreendidos em seus sofrimentos. Elas também denunciam os vínculos afetivos que constituem o sujeito, comunicando ao mundo algo de sua história e fazendo do corpo uma interface de troca. Complementando, podemos pensar com Chouvier (2008) que, quando o corpo ganha a cena na clínica, ele nos leva a interrogar sobre o início da vida psíquica do sujeito e suas primeiras etapas do desenvolvimento, abrindo para uma nova compreensão do que vem do soma.

Em relação a uma linguagem pré-verbal presente nas automutilações, encontramos em Roussillon (2008) uma ideia de que os atos, para além da tendência à descarga ou evacuação de conteúdos psíquicos, podem comportar ainda uma dimensão de linguagem, contendo valor mensageiro e de memória. Com base nos textos freudianos iniciais sobre as histéricas e suas atuações, assim como seus escritos mais próximos do final da vida sobre os atos psicóticos, Roussillon (2008) propõe ampliarmos esses estudos na direção de uma linguagem do ato.

Comportando as devidas diferenças entre as significações de cada ato, mais circunscrita aos domínios da representação ou mais arcaicos, anteriores à aquisição de linguagem verbal, o autor nos apresenta a hipótese de que os atos recontam (ou tentam recontar) uma história particular do sujeito, que por vezes nos remete à primeira infância e a um momento no qual o corpo e o pré-verbal estavam na frente da cena. Com isso, podemos pensar que o corpo conta a história das relações interpessoais das origens, dos primeiros vínculos construídos com um outro, próprios ao início intersubjetivo da vida.

Dessa forma, podemos pensar que, se é o corpo que conta a história das primeiras relações com o mundo, então estamos supondo que há um registro desses acontecimentos que não necessariamente estão circunscritos ao psiquismo. Tendo como norte as vivências automutilatórias de nossos pacientes, podemos nos questionar acerca das memórias sensoriais que envolvem esta prática. Quando um 
sujeito recorre ao sensorial com o intuito de machucar o próprio corpo, que tipos de registros ele está evocando?

Roussillon (2004a) apresenta a hipótese de que toda comunicação de um ser humano adulto, ou já dotado de palavras, deve ser considerada em diferentes níveis e modalidades de organização, especialmente um nível pré-verbal e outro pós-verbal, que convivem lado a lado durante toda a vida.

No que diz respeito ao pré-verbal, Roussillon (2011) destaca duas formas principais através das quais o bebê se comunica: 1) utilizando os afetos; 2) através de uma linguagem mimo-gesto-postural. Os conteúdos presentes anteriormente ao registro da linguagem falada são guardados e expressos pelo corpo. É ele que comporta elementos que podem se fazer presentes de outras formas, através de seus gestos, seus mimetismos, suas posturas, sua motricidade, seus atos e seus afetos. É ele que nos dá notícias de uma linguagem primeva (Roussillon, 1999; 2012a, 2012b).

Tanto em uma dimensão pré-verbal quanto em uma pós-verbal estão implícitos diferentes níveis de simbolização e inscrição psíquica, necessários para que essas formas possíveis de linguagem sejam adquiridas. Enquanto a simbolização linguageira (em ação no campo da comunicação pós-verbal) já teria sofrido um processo no qual a matéria bruta se transformou em símbolo, o primeiro tempo da simbolização diz respeito a experiências mais precoces vividas pelo sujeito e que teriam sido registradas de formas diferenciadas.

Propondo uma discussão acerca das origens da linguagem verbal, Golse e Desjardins (2005) evocam os dois grandes registros clássicos no domínio da comunicação: a analógica e a digital. Enquanto a comunicação analógica, também chamada de infraverbal ou pré-verbal, é responsável por veicular, principalmente, emoções e afetos, transmitindo não-verbalmente mensagens com conteúdos emocionais através de comportamentos não linguísticos (através de mímicas, olhares e gestos); a comunicação digital diz respeito a conceitos, veiculando constructos mais globais através da transmissão verbal de mensagens com conteúdos conceituais ou ideativos através de comportamentos linguísticos (a própria fala, palavras, frases e locuções verbais).

$\mathrm{Na}$ mesma direção proposta por Roussillon, Golse e Desjardins (2005) consideram que estes diferentes níveis e modalidades de comunicação não devem ser compreendidos hierarquicamente, no sentido de que um passaria a substituir o 
outro, mas que ambos se complementam após a aquisição da linguagem verbal. A ideia seria conjugarmos ambos os níveis com o intuito de acumular elementos diferentes que auxiliariam ainda mais a mensagem passada, aumentando as chances de sua compreensão pelo interlocutor. Levando em consideração as diferenças dos elementos infraverbais e linguísticos, podemos apostar na importância da singularidade de ambos os campos para que o sucesso do alcance da mensagem possa ser ainda maior.

No que concerne ao registro das experiências no psiquismo, Freud (1950[1896]/1996a), na Carta 52, descreve de forma esquemática algumas formas de registro da memória, destacando quatro níveis de registro: 1) W [Wahrnehmungen (percepções)]: neurônios nos quais se originam a percepção, mas que nada retém do acontecido; 2) Wz [Wahrnehmungszeichen (índices de percepção)]: primeiro nível de registro do que foi percebido, formando associações por simultaneidade; 3) Ub [Unbewusstsein (inconsciência)]: segundo nível de registro, com provável relação causal entre o que é registrado; e 4) $\mathrm{Vb}$ [Vorbewusstsein (pré-consciência)]: terceiro nível de registro, ligado a representações verbais. Podem tornar-se conscientes de acordo com certas regras.

Interessante notarmos que este manuscrito instaura a possibilidade de pensarmos na memória como um evento que possui diferentes formas de registro e que acontece em diversos tempos, diferentemente de uma linearidade temporal, caminhando de forma única e imutável do passado na direção do futuro.

No contexto do presente trabalho, nos interessamos em explorar os elementos Wz, os chamados índices de percepção, nos quais encontramos os primeiros registros perceptivos, que ainda não acederam ao verbal. De acordo com Maldonado (2012), estes seriam compreendidos como signos não ligados e não estariam, ainda, inscritos no sistema inconsciente. Eles adotariam a forma de índices ou marcas, e não de traços representativos e, em última instância, darão lugar a uma memória da ordem das marcas e das impressões, e não de traços representativos. Diferentemente do traço, a impressão não pressupõe uma inscrição, configurando um tipo diferenciado de memória, mais próxima dos elementos sensoriais (Cidade \& Zornig, 2016).

A partir desse esquema, diversos autores equivalem o processo de simbolização à passagem das representações-coisa às representações-palavra. Mais recentemente, tem havido um movimento que propõe ampliar a 
compreensão dos processos de simbolização, pondo a ênfase não apenas na passagem das representações-coisa às representações-palavra, mas incluindo também a transformação dos índices de percepção em representações-coisa.

Baseado neste movimento de ampliação, Roussillon (1999) divide os processos de simbolização em primários e secundários. A simbolização primária obedece ao processo primário e liga as primeiras inscrições psíquicas aos primeiros símbolos - os índices de percepção às representações-coisa, segundo registro da memória. Este trabalho culmina no surgimento da representação-coisa no Inconsciente, estando anteriormente sob a forma de traços de percepção registro complexo e rico em dados, porém imaterial.

As experiências próprias a um primeiro tempo de simbolização, Roussillon (1999) chamou de processos de simbolização primária, contribuição à Psicanálise que surge como tentativa de ampliar teoricamente os alcances da teoria da simbolização e da representação. Visando à construção do conceito, Roussillon (1999), baseado no esquema de memória apresentado por Freud na Carta 52, aponta que existem dois níveis de trabalho de simbolização ocorrendo entre os três registros mnêmicos: uma primeira transformação dos índices de percepção em representação-coisa; e uma segunda, das representações-coisa em representaçõespalavra.

Ao evocar a pluralidade e a complexidade da memória humana, Roussillon (2006a) retoma a ideia freudiana de que o aparelho psíquico é também um aparelho de memória. Neste cenário, o autor descreve o que chamou de memória perceptiva, que equivaleria a um primeiro momento de registro, o dos índices de percepção $(\mathrm{Wz})$. Estes compõem o primeiro registro de dados fornecidos pela percepção e só podem se tornar conscientes de forma alucinatória, já que ainda não há uma dimensão de elaboração do percebido. São a inscrição primeira e fundamental do material bruto da experiência. De acordo com Roussillon (2015), este material é complexo, multiperceptivo e multissensorial, pois seu acesso provém pelas cinco vias de sentido.

Para melhor exemplificar a diferenciação entre o que chamou de simbolização primária e secundária, Roussillon (1999, 2012b) apresenta o modelo freudiano do sonho sonhado/sonho narrado. Para produzir o sonho sonhado, já há um trabalho primeiro de simbolização, no sentido de que algo do registro das sensações se transveste em registro conceitual, em representação-coisa. A este 
trabalho, damos o nome de simbolização primária. Já o modelo do sonho narrado equivaleria à simbolização secundária, uma vez que há uma segunda transformação para que o sonho possa vir a ser contado, permitindo sua entrada na linguagem verbal.

Os processos de simbolização falam sobre como as diferentes experiências vividas pelo sujeito são registradas e evocadas - seja no corpo, seja no psiquismo, seja em ambos. Enquanto as experiências próprias aos processos de simbolização secundária teriam sido registradas prioritariamente no psiquismo, as experiências próprias aos processos de simbolização primária teriam sido prioritariamente registradas, sobretudo, no corpo, como memória perceptiva.

Em seu artigo sobre as lembranças encobridoras, Freud (1899/1996b) aponta que as experiências vividas nos primeiros anos da infância deixam marcas indeléveis em nós, apesar de não conseguirmos ter acesso exato a elas. Em suas palavras:

\begin{abstract}
Ninguém contesta o fato de que as experiências dos primeiros anos de nossa infância deixam traços inerradicáveis nas profundezas de nossa mente. Entretanto, ao procurarmos averiguar em nossa memória quais as impressões que se destinaram a influenciar-nos até o fim da vida, o resultado é, ou absolutamente nada, ou um número relativamente pequeno de recordações isoladas, que são frequentemente de importância duvidosa ou enigmática. (Freud, 1899/1996b, p. 287)

$\mathrm{O}$ autor se refere a estas experiências como "impressões precoces" e diz que este efeito enigmático do que se passou é justamente o infantil que perdura em cada um de nós e que os vividos não necessariamente deixarão uma imagem mnemônica guardada em nossa memória. Sendo assim, não seria o registro na dimensão do corpo que Freud estaria evocando nessa passagem?
\end{abstract}

Em Moisés e o monoteísmo, Freud (1939[1934-38]/1996k) retoma a noção de impressões precoces e ressalta que as primeiras experiências são as que mais nos marcam, aquelas que remontam a um tempo bastante inicial da infância. Destas, só podemos guardar impressões, uma vez que nem sempre temos acesso ao aparelho de linguagem quando elas acontecem. Porém, estas impressões podem ser bastante fortes e ficariam atreladas ao corpo próprio ou às percepções sensoriais vividas pelo sujeito, em especial aquelas de ordem visual e auditiva. Complementando, Fontes (2010) aponta que o conceito freudiano de impressões precoces diz respeito à receptividade do dispositivo pulsional e psíquico em 
relação ao que foi vivido, de forma que a impressão seria uma consequência direta da experiência vivida.

Na mesma direção, o casal Botella (2002) também sublinha a contribuição freudiana de que a memória é composta por diferentes tipos de signos, o que a torna bastante particular. As conexões entre tais signos não estão restritas aos limites dos órgãos dos sentidos e nem à temporalidade e à espacialidade, não contendo, portanto, nenhum determinismo ou causalidade a priori. Nas palavras dos autores, "é a simultaneidade dos signos e sua perceptivação que representa uma potencialidade causal" (p. 196). Ao invés de nos referirmos à causalidade de algum evento como o passado determinando o presente, o casal defende uma potencialidade de causalidades que podem vir a ser, uma vez que a memória é composta por uma pluralidade de signos diferentes.

Após esta breve exposição teórica sobre a memória e suas diferentes formas de registro, podemos afirmar que as experiências vivenciadas precocemente deixam marcas e registros em um nível diferente daquelas da vida adulta, se inscrevendo em formato pré-verbal, da ordem do arcaico e do sensorial. Com base nas contribuições de Albert Ciccone (2008) sobre as experiências precoces, gostaríamos de sublinhar que estas produzem efeitos no desenvolvimento de todo sujeito, de modo que não se tratam de experiências estanques, com começo, meio e fim, mas de formas de se relacionar e de estar no mundo que se encontram presentes ao longo de toda a vida.

$\mathrm{Na}$ automutilação, não apenas o corpo é convocado para dar conta de um sofrimento que não está posto em palavras, mas há uma dimensão de ataque à própria pele do sujeito, envelope corporal que marca uma diferença entre dentro e fora, sujeito e objeto. A pele contém uma premissa de integração, de unidade, construída em um tempo no qual a existência se encontrava atrelada apenas ao corpo e às sensações, sem a dimensão da palavra.

\section{3}

\section{A pele que habito}

No que diz respeito às condutas de automutilação, ampliando a dimensão do corpo que aí se encontra presente, podemos pensar acerca da especificidade deste ato: a agressão à própria pele como condição de possibilidade para o ato em 
si. A matéria primordial a ser utilizada nessas práticas é a pele, envelope corporal e psíquico que delimita fronteiras entre os mundos interno e externo. Neste cenário, podemos nos perguntar qual a relação existente entre a pele e as condutas de automutilação. Por que, nestas condutas, a pele é o órgão de ataque escolhido? Que notícias podemos ter acerca destas práticas se compreendermos o papel da pele na constituição psíquica dos sujeitos, assim como nas relações que surgem a partir deste envelopamento corporal?

Podemos pensar que a primeira relação que desenvolvemos com o mundo parte de nosso contato corporal com o outro, no chamado, popularmente, de "pele a pele". De acordo com Le Breton (2010), antropólogo e sociólogo francês, a pele tem uma importância ímpar como lugar de relação e comunicação com o mundo e consigo. Ela permite que sejamos reconhecidos enquanto indivíduos, ou seja, é por causa do "acabamento" fornecido pela pele que podemos ser nomeados e identificados como nós mesmos. O sentimento de que somos nós mesmos se enraíza a partir das sensações corporais experimentadas através da pele, instância de fabricação de identidade. A pele também fornece informações em relação a nossos pertencimentos e histórias. O autor ressalta que ela é o primeiro lugar (e também o mais primordial) de contato com o outro e afirma que "ela enraíza o sentimento de si em uma carne que individualiza" (p. 87, tradução nossa).

Um teórico que bastante contribuiu para os estudos sobre a pele como tendo um lugar de importância nos primórdios do psiquismo foi o psicanalista francês Didier Anzieu, em especial seus escritos acerca do que denominou de $\mathrm{eu}$ pele. A partir de suas observações advindas dos atendimentos psicológicos fornecidos aos pacientes do setor hospitalar de Dermatologia (especialmente pacientes que sofriam de eczemas graves), Anzieu começou a intuir a importância da pele na constituição psíquica, assim como nas relações intersubjetivas.

Apoiado no campo da Biologia, Anzieu (1985/2000) aponta a complexidade advinda da pele, à qual ele considera "mais que um órgão" (p. 29), uma vez que seria dotada de estrutura, funções e importância ímpar. Em relação aos outros órgãos dos sentidos, a pele é destacada pelo autor como a mais vital: é possível viver sem a visão ou audição, mas sem a integridade da maior parte da pele não é possível sobreviver. A pele possui ainda mais peso físico e ocupa uma superfície maior do que qualquer outro órgão do corpo humano, contendo uma grande densidade de receptores, o que a permite estar em profunda conexão com 
os outros órgãos do sentido. Na mesma direção, destacamos a importância atribuída às funções da pele, uma vez que ela surge no período embrionário bem antes dos outros sistemas (por volta do fim do segundo mês de gestação), e que a Biologia relaciona a precocidade do aparecimento das funções do corpo humano com sua importância em termos do desenvolvimento maturacional.

Para além da importância da pele do ponto de vista biológico, ressaltamos, com Anzieu (1985/2000), que ela é, ao mesmo tempo, substrato orgânico e imaginário, que possui como função proteger nossa individualidade e fundamentar nossa troca com o outro. Inspirado no eu-corporal de Freud (1923/1996h) e no valor que o mesmo atribui à pele como principal fonte da qual derivam as sensações que posteriormente auxiliarão a formar o ego, Anzieu (1985/2000) traz à tona uma discussão importante acerca da constituição do eu como espaço psíquico continente. Tendo como base os trabalhos de Bion sobre o espaço mental como continente e a gênese da capacidade de pensar, Anzieu (1985/2000) formula uma origem corporal para todo o processo de pensar, sugerindo que o bebê "aprende" a pensar a partir do corpo - a construção do continente psíquico implica nas experiências vividas no corpo primitivo. Complementando com Fontes (2010, p. 62), "poderíamos dizer que a pele ensina o ego a pensar".

Ainda com base nas considerações de Anzieu (1985/2000), podemos pensar que o psiquismo se apoia nesta função reflexiva da pele para, posteriormente, constituir um desdobramento reflexivo do eu consciente, de forma que o pensamento nasce a partir do corpo. Nessa direção, Cupa (2006) aponta que é baseado neste modelo da reflexividade tátil que se constroem outras reflexividades posteriores: se ver, se ouvir, se cheirar, se provar; até finalmente chegarmos na reflexividade do pensamento verbal, uma vez que "o código linguístico é o único que pode pensar a si mesmo" (p. 88, tradução nossa).

Ressaltamos, com Anzieu (1985/2000), que a atividade psíquica se estabelece a partir de uma atividade corporal, se apoiando em uma função biológica. A partir daí, podemos aprofundar esse pensamento afirmando que o eu se ancora em um corpo pré-verbal, fonte das primeiras experiências sensóriomotoras e das primeiras comunicações. De acordo com Mano (2013), a proposta de Anzieu é inovadora para a época, uma vez que propõe esse corpo pré-verbal como mediador do mundo, lugar de trocas e de domínio do sentimento de 
existência. Dessa forma, temos uma atividade de pensar que se ancora no corpo e um eu-psíquico que se ancora em um eu-corporal.

Nesta direção, faz-se necessário ressaltar que há uma dimensão da temporalidade nestes conceitos que não pode ser restringida a uma linha do tempo desenvolvimentista, na qual uma nova fase substituiria a anterior, mas que aponta para experiências e vivências do eu que coexistem no tempo e no espaço. Gostaríamos de ressaltar que a dimensão corporal da experiência do eu não se apaga e nem é substituída por uma nova experiência "mais elaborada" de ser, mas que estas experiências são formas diferentes de estar no mundo, de modo que o sujeito vai adquirindo diferentes níveis de acesso e de relacionamento com o entorno.

Corroborando o que Corcos (2009/2013) e Dargent e Matha (2011) propuseram acerca das automutilações como um recurso ao corpo em um cenário no qual o acesso ao pensamento está prejudicado e destacando a dimensão de um ato que visa à própria pele do sujeito, encontramos suporte nas teorias de Anzieu (1985/2000) acerca da importância da pele e do corpo nas origens do psiquismo.

Em seu artigo intitulado La peau: du plaisir à la pensée, Anzieu (1974/2007) faz uma apresentação inicial do fenômeno, descrevendo-o como "a primeira diferenciação do eu no âmago do aparelho psíquico se apoia sobre as sensações da pele e consiste em uma figuração simbólica da mesma. É isto que eu proponho chamar de eu-pele" (Anzieu, 1974/2007, p. 22, tradução nossa). Alguns anos mais tarde, Anzieu (1985/2000) publica um livro intitulado O Eu-Pele, no qual complementa sua descrição:

por eu-pele designo uma representação de que se serve o eu da criança durante fases precoces de seu desenvolvimento para se representar a si mesma como eu que contém os conteúdos psíquicos, a partir de sua experiência da superfície do corpo. (p. 61)

Partindo das definições apresentadas, podemos compreender que a noção de eu-pele é a primeira representação que o eu faz de si mesmo, na qual já haveria a possibilidade de conter conteúdos, mas com a capacidade de representar ainda bastante precária. Anzieu (1985/2000) propõe que pensemos o eu-pele como uma metáfora, uma vez que ele se encontra entre um eu-corporal e um eu-psíquico. O eu-pele se ancora no eu-corporal na tentativa de se apropriar das sensações experimentadas e de organizá-las em algum formato possível de representação. 
Nos casos de automutilação, essa capacidade de contenção estaria prejudicada. Dargent (2010) relaciona essa prática com falhas importantes, quantitativa e qualitativamente, na constituição do eu-pele. Segundo a autora, há um ataque ao corpo, evidenciando falhas bastante profundas na constituição egoica dos sujeitos em questão. Tais práticas aparecem como linguagem do corpo, privilegiada em um momento no qual ainda não havia palavras para ajudar a compor a experiência, apenas o registro pré-verbal. Partindo destas contribuições, podemos nos perguntar acerca dos prejuízos que adviriam destas falhas precoces na constituição do eu-pele. Apresentando a importância do eu-pele e de suas funções para o próprio sujeito e a repercussão de sua constituição também na relação com os outros, esperamos compreender melhor as práticas de automutilação.

Para a criação do conceito de eu-pele, Anzieu (1985/2000) tem como base a segunda tópica freudiana, especialmente a partir de Além do princípio do prazer (1920/1996g) e de O ego e o id (1923/1996h), quando Freud modifica sua imagem plana de representação do aparelho psíquico no "modelo pente" para o "modelo tridimensional da vesícula". Anzieu (1985/2000) aponta que esta passagem corresponde ao deslocamento de um enfoque dado aos conteúdos psíquicos (conscientes e inconscientes) para uma compreensão do psiquismo como entidade continente, que possibilita a entrada em um mundo 3D. Fechando suas observações com Uma nota sobre o bloco mágico (Freud, 1925[1924]/1996i), Anzieu (1985/2000) observa o apoio do eu sobre a pele, uma vez que encontra neste texto a estrutura topográfica do eu descrita como o equivalente a um envelope continente.

Retomando a ideia de Anzieu (1985/2000) de que a atividade psíquica se apoia em uma função biológica, o eu-pele, então, se desenvolveria encontrando apoio nas diversas funções da pele, dentre as quais o autor destaca três: 1) a função de contenção, na qual a pele funcionaria como uma espécie de bolsa que contém e retém algo em seu interior; 2) a função de proteção, sendo a pele uma barreira que protege da intervenção do mundo externo, tida como superfície de separação e demarcando um limite entre dentro e fora; e 3) a função de comunicação, na qual a pele surge como lugar e meio através dos quais as relações entre sujeito e objetos e/ou outros sujeitos serão estabelecidas. 
O eu-pele se constitui enquanto envelope psíquico contendo duas camadas que diferem em estrutura e função. Tendo como origem essa dupla herança epidérmica e proprioceptiva, encontrada na própria pele, o eu-pele adquire a possibilidade tanto de estabelecer barreiras (entre fora e dentro, estando na base de todo o limite entre o eu e o outro), assim como de filtrar as trocas (entre as instâncias psíquicas internas e entre mundo interno/mundo externo).

Nesta direção, em consonância com Cupa (2006), podemos pensar em um duplo envelopamento que adviria no eu-pele, constituído por um eixo de excitação e um eixo de comunicação. A autora esquematiza o pensamento de Anzieu, destacando a presença de dois envelopes possíveis: o envelope de excitação e o envelope de comunicação. Baseado nos escritos freudianos de 1920 sobre o modelo da vesícula e de paraexcitação, o envelope de excitação seria constituído por uma camada voltada para o mundo externo que mediaria qualquer estímulo recebido, protegendo o mundo interno - a realidade psíquica. Por um lado, este envelope permite que parte da excitação passe, filtrando as quantidades (de prazer e de dor); por outro, o paraexcitação mantém em um sistema fechado o montante pulsional, até que uma descarga se torne necessária.

Já o envelope de comunicação, baseado nas notas sobre o bloco mágico de Freud, seria a segunda camada existente no eu-pele. Ele seria constituído por uma camada interna, voltada para os sinais sensoriais, cinestésicos, e para o funcionamento psíquico. Tal envelope possui uma dupla face, voltada para o mundo interno e externo, constituindo uma interface que separa os dois mundos, mas os coloca em comunicação. Cupa (2006) propõe que é o envelope de comunicação que permite o acesso à reflexividade, uma vez que sua camada interna possui uma face voltada para fora e uma face voltada para dentro, o que possibilita a criação de uma zona de contato entre sujeito e objeto. De acordo com a autora, pode-se dizer que o primeiro envelope filtra as quantidades, enquanto o segundo filtra as qualidades das experiências.

Dessa forma, cada um dos envelopes que constituem o eu-pele possui uma função diferente e complementar. O primeiro envelopa o sujeito e dá a ele a possibilidade de contenção e de filtragem das intensidades que o atinjam através do sistema de paraexcitação. Já o segundo liga o mundo interno ao mundo externo, tornando possível a comunicação entre as próprias sensações do mundo interno, assim como estabelecendo uma ponte entre esses dois mundos. 
Compreender o eu-pele como um envelope é fundamental, na medida em que nos informa que através dele o sujeito passa a possuir uma noção de integração que é amparada pela própria pele. Neste sentido, a pele passa a conter uma premissa de integração, de unidade. Se, por um lado, a pele marca um distanciamento entre o ambiente e o mundo interno, constituindo-se como uma espécie de fronteira que marca os limites da própria existência, ao mesmo tempo, é ela que vai mediar a relação com os outros (Douville, 2004).

No que diz respeito à importância da pele na relação entre sujeitos, encontramos em Anzieu (1985/2000) uma fantasia de pele comum à mãe e ao bebê nos primórdios da vida psíquica, na qual haveria a troca direta, tanto das excitações quanto das comunicações entre ambos, levando o bebê a ter a sensação de que sua pele se encontra colada à da mãe. Há uma fantasia de indiscriminação de peles necessária para a constituição psíquica do bebê, que aos poucos vai "arrancando" a pele da mãe até sentir-se ele próprio.

$\mathrm{Na}$ mesma direção, encontramos nas contribuições de Joyce McDougall (1987) a noção de um corpo para dois: a fantasia constitutiva de todo ser humano de "fazer um" com a mãe-universo da primeira infância. De acordo com a autora, encontraríamos o protótipo biológico desta fantasia nas vivências intrauterinas, nas quais o corpo materno sustentava e provia todas as necessidades vitais do embrião, assim como suas próprias necessidades biológicas, sendo fonte de energia e existência, ao mesmo tempo, dos dois seres envolvidos. A partir desta primeira fantasia somatopsíquica, uma diferenciação progressiva entre o par mãebebê vai começando a se formar, distinguindo aos poucos ambas as personagens, assim como o psíquico vai também se diferenciando do somático.

Cabe ressaltar que, em relação ao momento inicial do par mãe-bebê, estamos em consonância com a ideia de que existiria um gradiente dinâmico e progressivo entre os estados de indiferenciação primitiva e de intersubjetividade, baseadas nos escritos de Golse e Roussillon (2010), de forma que não compartilhamos da visão de um início totalmente indiferenciado e fusionado entre o par. Apesar disso, ressaltamos a dimensão importante desta fantasia apresentada por Anzieu (1985/2000), que evoca a importância do outro enquanto objeto que auxilia a tornar possível a constituição subjetiva do bebê - neste caso, a partir do compartilhamento fantasmático de peles, assim como da fantasia de dois corpos compartilhados de McDougall (1987). 
De acordo com Anzieu (1985/2000), o eu-pele da mãe serve de apoio e sustento, contribuindo para a constituição do eu-pele do bebê. Nesta direção, Cupa (2006) ressalta que o eu-pele é um envelope de maternagem, termo de Brazelton retomado por Anzieu (1985/2000), uma vez que, inicialmente, a mãe é o próprio envelope - desde a vida intrauterina, o útero funciona como espécie de vesícula protetora. A função de paraexcitação é constituída, a princípio, pelo ventre materno, possibilitando o desenvolvimento de um campo de sensibilidade comum a ambos.

De acordo com Nunes (2012), a mãe deve auxiliar a criar uma experiência de continente para o bebê. $\mathrm{O}$ eu-pele envolve e protege o psiquismo, assim como a pele envolve e protege os órgãos internos do corpo. Nesse sentido, a pele do bebê vira palco de toda uma sensorialidade que demarca a superfície do corpo, originando também uma superfície psíquica. A partir da troca corporal com a mãe, o bebê começa a constituir um "dentro" e um "fora", garantindo um limite, assim como a integridade de seu envelope corporal. Dessa forma, o eu-pele também se configura como uma estrutura intermediária entre a mãe e o bebê, de forma que a confusão inicial de peles vai dando lugar à diferenciação entre as peles física e psíquica de ambos. Todavia, para que o eu-pele se constitua, faz-se necessário que as experiências de troca entre mãe e bebê ocorram de forma satisfatória e no momento adequado (Anzieu, 1985/2000).

No que diz respeito à automutilação, este início não teria acontecido de forma minimamente satisfatória, deixando uma série de falhas na constituição deste envelope psíquico. Estas falhas se inscrevem no corpo, culminando em um envelope perfurado que não dá ao sujeito a segurança necessária para sentir-se coeso e integrado. Nesse sentido, nossa hipótese é a de que o recurso ao corpo nas automutilações surge como uma tentativa de contenção do eu em momentos nos quais o sujeito sente que pode haver o risco da perda da integridade narcísica.

Essa ideia vai de encontro às contribuições deixadas por Freud (1941[1938]/19961) no fim de sua vida, a respeito da inscrição das impressões pré-verbais. Se, por um lado, ele afirma que os acontecimentos mais precoces, quando o ego ainda não está em condições de sintetizar e/ou metabolizar as experiências vividas por ele, ficam registrados de forma mais intensa no corpo do sujeito, ele também ressalta a fraqueza do poder de síntese egoica encontrada no momento da experiência (Roussillon, 2012b). 
Se, nas condutas automutilatórias, encontramos um ego fragilizado e ameaçado pelo risco da perda da integridade narcísica, podemos pensar que, neste momento bastante inicial da vida, no qual os acontecimentos precoces são registrados no corpo, estes sujeitos teriam vivido uma série de experiências para as quais o ego ainda não estava preparado psiquicamente para elaborá-las, deixando como rastro uma série de falhas na constituição psíquica. As vivências ocorridas nos momentos de constituição do eu-pele não teriam se passado de forma satisfatória entre o par mãe-bebê, culminando em falhas narcísicas e na possibilidade de contenção e de integração daquele sujeito.

McDougall (1987) aponta que o fracasso no processo inicial da fantasia de compartilhamento de um mesmo corpo entre o par mãe-bebê pode levar a dificuldades futuras na "capacidade da criança de integrar e de reconhecer como seus o seu corpo, seus pensamentos, seus afetos” (p. 20). Tal comprometimento inicial levaria o bebê a procurar recriar a ilusão de unidade corporal em momentos de sofrimento físico ou psíquico. Esses sofrimentos assegurariam a existência daquele sujeito, encarnando a problemática no corpo e em uma realidade puramente biológica, na tentativa de extinguir (ou preservar) o psíquico.

Interessante ressaltar que há um paradoxo intrínseco à fantasia de compartilhamento do mesmo corpo descrita por McDougall (1987): se, por um lado, o bebê a utiliza como recurso diante das frustrações advindas da cesura do nascimento, por outro, há uma dimensão de recusa a uma completa fusão, lutando para diferenciar-se do corpo e do ser da mãe. Neste fenômeno, o ato de machucar a própria pele contém em si uma luta similar à da fantasia primordial de união.

$\mathrm{Na}$ mesma direção, Corcos e Richard (2006) compreendem as automutilações como investimento de uma representação de si que tenta construir uma diferenciação entre si mesmo e o objeto. Os autores afirmam que os sujeitos que se automutilam teriam grande dificuldade em se ver separados de seus objetos primários, em particular a mãe (ou cuidador primordial), por conta de um vínculo inicial insatisfatório, no que diz respeito a se sentir seguro em relação a seus próprios limites e os limites do outro. Existiria uma tentativa de se tornar mais autônomo por detrás destes atos, assegurando seus próprios limites através do corpo.

Em consonância com Roussillon (2007), apontamos que a problemática central da pele é a da diferenciação eu/não-eu, uma vez que a função principal do 
eu-pele seria realizar um primeiro esboço de delimitação entre o eu e o ambiente. Um envelope tátil que delimita um interior e um exterior, formando uma barreira protetora que pode selecionar o que entra e manter fora o que não lhe pertence. Contudo, conforme apontado anteriormente, este processo de diferenciação que culminará no limite entre sujeitos só pode se efetuar se um primeiro tempo tiver se passado de forma satisfatória: o da construção da fantasia de uma pele comum entre mãe e bebê. As nuances deste momento compartilhado pelo par vão constituir as particularidades do processo de diferenciação, podendo levar a falhas prematuras no processo.

McDougall (1987) aponta que separação e diferença não são necessariamente vivenciadas pelo par mãe-bebê como uma conquista psíquica positiva, podendo, em um contexto de falhas estruturais, serem vivenciadas como uma verdadeira ameaça ao eu e "temidas como realidades que diminuem e esvaziam o sujeito daquilo que lhe parece vital para sobreviver" (p. 23). Nesses casos, o temor seria de despedaçamento, caso houvesse o rompimento da unidade mãe-bebê ainda na ilusão de um corpo fusionado, levando a uma impossibilidade de deixar esse compartilhamento de corpos e culminando em uma vivência de um corpo fragmentado, com pedaços próprios e pedaços do outro misturados, indissociáveis e irreconhecíveis como separados.

Podemos pensar que, no caso das automutilações, sujeito e objeto não estão devidamente diferenciados, de forma que há uma confusão entre ambos os corpos e os limites do sujeito encontram-se falhos, denunciados pela problemática trazida à tona pelo ataque à própria pele.

Nesse cenário, faz-se necessário refletirmos acerca da qualidade da presença do objeto neste momento inicial da constituição psíquica, uma vez que a construção da fantasia da pele comum depende da qualidade dos cuidados maternos e da sintonia e da comunicação precoces estabelecidas entre o par mãebebê. É o campo sensório-motor que, no momento inicial da vida, se encontra em primeiro plano, tanto no nível da experiência (das sensações experimentadas), quanto no nível da comunicação, do compartilhamento de afetos entre ambos, e esse campo é sentido através das relações entre as peles.

Complementando esta linha de pensamento, Aragão (2018) coloca que o compartilhamento sensório-motor do par mãe-bebê opera por meio de microtrocas e ajustamentos microposturais entre o bebê e a mãe, assim como a partir da 
ritmicidade conjunta que se constitui entre ambos. Neste momento de constituição do eu-pele, a presença do outro é fundamental para que o sujeito passe a se sentir envelopado e habitando sua própria pele, tanto física quanto psíquica. Para que este caminho se desenvolva, o sujeito precisa conseguir ir "descolando" aos poucos sua pele da pele materna, constituindo seu próprio envelope, único e distinto do envelope de sustentação da mãe.

Dessa forma, podemos pensar que, se a qualidade de presença do outro não foi suficiente, gerando problemas nos vínculos e relações com os objetos, a capacidade do sujeito de habitar a própria pele e de se sentir integrado e coeso pode ficar prejudicada. Nesse caso, os objetos podem vir a ser sentidos como ameaçadores, uma vez que os limites entre sujeito e objeto não estão estabelecidos de forma segura ou garantidos no tempo e espaço. Se a pele é o órgão que delimita fisicamente onde termina o sujeito e começa o objeto, o ataque à pele nos dá notícias deste limite falho e de uma "confusão de peles" que permanece ao longo da história do sujeito. 


\section{3 Automutilação e constituição psíquica: descontinuidades
nos processos de subjetivação}

Porque ao princípio é o ritmo; um ritmo surdo, espesso, do coração ou do cosmos - quem sabe onde um começa e o outro acaba?

Eugénio de Andrade

Problematizando o terreno das automutilações, percebemos que este fenômeno deixa em evidência o registro do corpo, em especial o da pele. São atos que visam agredir a pele de diferentes maneiras e em diferentes contextos. Contudo, não acreditamos que eles estariam ligados apenas a uma destrutividade aparente. Em Psicanálise, a pele tem estreita relação com o início da vida e o nascimento do psiquismo. Ela faz referência a uma noção de integração (corporal, assim como psíquica) e de continuidade, sendo através de sua apropriação que o sujeito começa a compreender a diferença entre eu e não-eu e a tecer suas relações consigo e com o mundo.

A pele também remete à sensorialidade e às primeiras noções de eu, estreitamente vinculadas ao corpo e às sensações. Para que uma integração do corpo e do psiquismo aconteça, será necessário um outro que cuide e se ocupe do bebê, desempenhando uma função materna e de alteridade. Assim, entramos no registro da intersubjetividade, de forma que temos, inicialmente, nossa sobrevivência e, posteriormente, nossas funções psíquicas e sentimento de si, atrelados, desde o início, à existência de um outro que cuida de nós e se coloca neste lugar de outro intersubjetivo.

Tendo o corpo e a pele como referencial, nos propomos a pensar sobre o início da vida psíquica a partir de uma dinâmica de constituição psíquica que leve em conta a intersubjetividade. A vida psíquica e a integração corpo-mente advêm dos elementos sensoriais e rítmicos, presentes já desde o útero, de acordo com contribuições mais recentes da Psicanálise, das Neurociências e da Psicologia do Desenvolvimento (Prat, 2007). Somos despertados pelas sensações e começamos a habitar nossos próprios corpos através delas. O corpo guarda uma história dos primórdios, que é sempre atual. 
Nessa direção, voltamos nossas atenções para explorar este início intersubjetivo, no qual começavam a se delinear sujeito e objeto como entidades separadas, nos debruçando sobre o processo de diferenciação que garante a ilusão de integridade narcísica.

\section{1 Automutilação e a questão da separação: ecos de uma história primeva}

Conforme explorado no capítulo anterior, o recurso ao corpo, e mais especificamente à pele, traz à tona a problemática da confusão de limites entre sujeito e objeto no início da vida, que se prolonga até a idade adulta - sempre em movimento contínuo de um tempo que não é linear, mas que se repete em espiral ao longo de toda a vida. Novamente ressaltamos que os vividos da primeira infância e da adolescência seguem fazendo eco aos novos vividos da vida adulta, sendo a compreensão de uma complexificação temporal bastante importante para o presente trabalho.

Se, nos casos de automutilação, os limites entre sujeito e objeto encontram-se confusos, podemos pensar que sujeito e objeto não estão devidamente diferenciados, de forma que há uma confusão entre ambos os corpos e as delimitações do sujeito encontram-se falhas. Nesses casos, observamos que a capacidade do sujeito de habitar a própria pele e de se sentir integrado e coeso está prejudicada, de modo que os objetos podem ser sentidos como ameaçadores, uma vez que as fronteiras entre sujeito e objeto não estão estabelecidas de forma segura ou garantidas no tempo e espaço.

Segundo Roussillon (2013), a questão dos limites entre sujeito e objeto nos reenvia para a problemática da separação, que ocupa um lugar importante na reflexão do presente trabalho. De acordo com o autor, a separação reflete um dos paradigmas essenciais da psicopatologia de nossa época. Se, por um lado, ela se relaciona com os conflitos psíquicos e edipianos, por outro, ela nos envia para um tempo primevo, no qual vivemos os primeiros encontros com o objeto e a construção dos primeiros vínculos intersubjetivos a partir dos quais o sujeito se constitui.

Esse tempo primevo tem relação com a pele, órgão que delimita fisicamente onde termina o sujeito e começa o objeto. $\mathrm{O}$ ataque à pele nos dá 
notícias deste limite falho e de uma "confusão de peles" e de corpos que permanece ao longo da história do sujeito, conforme discutido anteriormente. Nessa direção, o outro pode ser entendido como ameaçador ao eu, uma vez que ambos estão "misturados" em um retorno à fantasia de fazer "um" com o objeto primordial (Anzieu, 1985/2000; McDougall, 1987). Neste cenário, o sujeito recorre a si mesmo, uma vez que ambos estariam profundamente entrelaçados.

No que diz respeito à ameaça contida no outro, sentida pelo sujeito que se automutila, encontramos em um dos destinos pulsionais freudianos (Freud, 1915/1996f) essa retirada do investimento no mundo e direcionamento para si mesmo: o retorno ao próprio eu, uma vez que o objeto não chega a ser solicitado, sendo um ato que se resolve pela própria pessoa e no próprio corpo.

Neste caso, o objeto encontra-se confundido com o próprio eu, transformando uma problemática relacional em narcísica. Cria-se todo um circuito em torno do eu, fazendo do corpo o próprio objeto. O eixo narcísico-objetal fica confuso, uma vez que o objeto saiu de cena e o sujeito virou objeto, reflexivamente sendo sujeito e objeto da própria cena. Em consonância com Dargent e Matha (2011), gostaríamos de ressaltar que haveria tentativa de autorregulação narcísica, de forma que há esforço para resolver, no próprio corpo, questões que seriam de ordem relacional.

Sabemos, com Freud (1914/1996e), que as feridas físicas podem auxiliar na proteção contra o excesso pulsional que ameaça o eu e o coloca em risco de perda da integridade narcísica. Ao observar os soldados que voltavam da guerra, Freud (1920/1996g) constata que aqueles que tinham sofrido lesões físicas tinham menor chance de sofrer também com as consequências psíquicas desta experiência de sofrimento. Dessa forma, há contenção da energia psíquica que, ao invés de ficar livre, se descarrega nas feridas físicas. Partindo das contribuições freudianas, Dargent e Matha (2011) fazem uma correlação entre esse caráter de proteção das feridas físicas e a automutilação, na medida em que os machucados levam a um engajamento de contrainvestimentos narcísicos que ligam o excesso de excitação pulsional, protegendo o psiquismo.

No caso das feridas físicas (sejam autoprovocadas ou não), podemos dizer que o investimento narcísico se encontra privilegiado em detrimento dos investimentos objetais. A dor física é de natureza narcísica, conforme nos aponta Freud (1914/1996e) ao evocar algumas situações clássicas de retirada narcísica 
para o próprio eu, como a dor de dente. Nessa direção, Marty (2007) afirma que, em alguns casos, o narcisismo pode estar na origem de uma recusa a se engajar em investimentos objetais, que seriam percebidos pelo ego como ameaças em sua continuidade de existência.

A questão da dor física nos cenários de automutilação é controversa. Não há um consenso sobre o papel da dor nos estudos existentes, contudo, a maioria dos autores aponta que a busca pela dor não seria o elemento de principal destaque nestes quadros. Corcos e Richard (2006), Pommerau (2006b) e Dargent (2010) apontam para o fato de que muitos pacientes afirmam não sentir dor no momento em que estão se ferindo, destacando, pelo contrário, os sentimentos de alívio e apaziguamento trazidos pelo ato automutilatório. Corcos e Richard (2006) destacam que, enquanto a dor e a culpabilidade estariam mais relacionadas com elementos edípicos presentes nas automutilações, em um nível arcaico, os sentimentos de anestesia e vergonha dominariam a cena.

Nestes casos, o encontro com objetos seria tão ameaçador para o eu que a libido passaria a desinvestir os objetos externos e retornar para o próprio eu, mantendo-se a salvo. Acreditamos que este movimento se encontra em jogo nas automutilações. Há um retorno da libido para o próprio eu com o intuito de salvarse da ameaça contida em se relacionar com os objetos, assim como uma tentativa de inversão de um vivido passivo para um ativo (reflexivo, na verdade).

Pensando acerca de casos de automutilação acompanhados por nós, e outros dos quais temos notícias através da bibliografia pesquisada, percebemos que a questão da separação é primordial. Nos discursos dos pacientes, não há uma relação de causa e efeito entre a separação e as crises. Porém, observamos que as crises (e recaídas) costumam ser desencadeadas em um contexto de perda e/ou de separação de algum familiar, de um cônjuge ou pessoa a qual o paciente atribui uma importância ímpar, ou ainda na iminência dessa separação/perda. Há uma interrupção que pode ser a perda de um vínculo afetivo, seja um rompimento amoroso ou o término de uma grande amizade, ou uma interrupção que ocorre após uma perda real da pessoa em questão, em casos de falecimento. Nesses casos, a pessoa que ocupa um lugar de cuidado ou de proximidade essencial se ausenta, falece ou, por qualquer outra razão, deixa de ocupar esse lugar, mesmo que temporariamente. Cabe dizer que não devemos considerar apenas as 
experiências reais de separação, fatos da realidade concreta, mas a realidade psíquica que acompanha sempre os sujeitos.

Nesse sentido, podemos nos perguntar, qual seria a ameaça trazida pelo objeto? Por que a relação com outros sujeitos seria tão difícil para os indivíduos que se automutilam? Vimos que a automutilação pode ser um dos recursos radicais utilizados como forma defensiva frente ao colapso do eu, frente à ameaça de perda da integridade narcísica. Nossa hipótese é de que a ameaça de perda do objeto diante de uma vivência de separação transforma-se em ameaça de perda de si mesmo, uma vez que o sujeito e objeto estariam misturados.

É importante ressaltar que essa vivência de separação ou perda que antecede os atos automutilatórios costuma ser acompanhada de intenso sentimento de angústia e uma vivência de aniquilamento de si, podendo gerar sintomas físicos (dentre eles: tontura, falta de ar, sensação de "cabeça oca", nó na garganta ou dor no peito). Podemos pensar nas angústias impensáveis, de Winnicott (1974/1994), que levam o sujeito para um vazio da não-integração e o sentimento de nãoexistência. Nesses casos, como não há limite claro entre sujeito e objeto, a separação do outro pode levar ao sentimento de aniquilamento de si, uma vez que um objeto externo é investido narcisicamente por estar confundido com o eu.

Sobre a temática da separação, Jean-Michel Quinodoz (1991/2014) apresenta contribuições importantes. O autor compreende a separação como estando em um contexto de relação entre pessoas e a define como uma situação na qual uma pessoa se afasta de outra com a qual mantinha uma relação de confiança (seja temporariamente, seja de forma definitiva). A separação pode gerar sentimentos de solidão, tristeza, raiva ou dor, mas também de alívio e de liberdade, sem que um polo exclua o outro. Se essa separação é temporária, o afastamento do outro no tempo e no espaço não significa obrigatoriamente o fim do vínculo afetivo com o objeto ou sua perda de amor, uma vez que a relação não necessita da presença constante do objeto para ser sentida como real e contínua. A característica provisória da separação implica na esperança de retorno, mesmo que toda separação revele o medo de uma possível perda definitiva do outro ou de seu amor.

Contudo, na descrição fornecida acima, podemos afirmar que o indivíduo sabe em quem ele investiu, quem lhe faz falta e, o principal, sabe que ele é ele mesmo e continuará sendo, mesmo depois que a outra pessoa partir. Em outras 
palavras, a ausência da pessoa investida traz prejuízo para seu campo afetivo, mas não ameaça a estrutura egoica desse sujeito. Mesmo nas situações de separações definitivas, como um falecimento que convoca um trabalho de luto, a perda desse sujeito não leva à perda do próprio eu.

Quinodoz (1991/2014) ressalta a existência de outra forma de compreensão do fenômeno da separação: nesses casos, a ausência da pessoa considerada importante traz à tona uma angústia que é experimentada quando o sujeito se dá conta de que ele e o objeto não são um. Haveria a sensação de que o objeto leva consigo partes da própria pessoa quando se afasta. A ausência do outro traz a percepção dolorosa de sua presença como não-eu e estamos diante de um problema diferente, uma vez que a integridade narcísica do sujeito não está garantida. Para este fenômeno descrito, o autor propõe utilizarmos o termo “diferenciação", guardando a palavra separação apenas para o primeiro caso.

Sendo assim, temos duas operações possíveis que levam em conta a seara das separações: enquanto a separação propriamente dita pressupõe uma relação anterior entre dois sujeitos diferentes, contemplando a noção de que cada um é uno e discriminado perante o outro, de forma que, quando este outro, que não é igual, se vai, não há maiores riscos para o ego do sujeito que permaneceu; na diferenciação, a separação é vivida antes que surjam em cena dois sujeitos distintos, ou seja, sujeito e objeto ainda estão entrelaçados e confundidos. É indispensável que o processo de diferenciação esteja instaurado para que o sujeito possa suportar uma situação de separação sem sentir que uma parte do seu próprio eu é perdida junto com o outro que parte. Caso contrário, a separação será vivida como perda de uma parte de si, provocada pela perda do objeto.

Se as experiências de separação surgem excedendo as capacidades do bebê em momentos nos quais os processos de diferenciação ainda estavam sendo instaurados, pode haver falhas na capacidade futura do sujeito em lidar com as separações ao longo de sua vida, como parece ser o caso nos quadros de automutilação. Estas situações de sua história primeva fazem eco com situações anteriores de separações e perdas vivenciadas pelo sujeito ao longo de toda sua vida e que excederam suas capacidades de paraexcitação, culminando na estreita relação entre separação e automutilação.

Nesse sentido, podemos pensar que os fenômenos de automutilação constituem uma defesa frente a uma ameaça de perda do outro, que é sentida 
como ameaça de perda de seu próprio eu. Teria havido uma precocidade nas vivências de separação e ausência do objeto primordial, sem que os processos de diferenciação já estivessem operando no bebê, não respeitando seu tempo de constituição necessário. Nestes casos, a ausência precoce ou repentina do outro traz a percepção dolorosa de sua presença como não-eu, e estamos diante de um problema diferente, uma vez que a integridade narcísica do sujeito não está garantida.

A dificuldade de separação encontrada nos quadros de automutilação pode ser entendida como um reflexo da história inicial das relações objetais vividas por esse sujeito. Este fato nos remete ao início da vida psíquica, no qual sujeito e objeto ainda possuem limites bastante difusos. Uma questão importante para nós será compreender como o sujeito se funda com base na ilusão de ser quase indiscriminado de outro sujeito, mas precisa diferenciar-se dele para efetivamente se tornar um sujeito.

A partir da questão de como nasce um sujeito, podemos complementar a discussão com a questão de como nasce, também, o objeto. Importante entender a partir de quando o objeto começa a ser percebido como objeto e, posteriormente, como sujeito, o que abre para pensarmos a questão do início da vida através da intersubjetividade. Com base nos trabalhos de Golse e Roussillon (2010), podemos afirmar que o início do psiquismo e o nascimento do objeto são indissociáveis, uma vez que o sujeito vai caminhando rumo à autonomia e, com isso, o objeto vai se tornando cada vez mais perceptível como objeto separado do sujeito. A ausência objetal só pode se tornar suportável para a criança, uma vez que tenha havido, anteriormente, uma presença suficiente do objeto, de forma que ele possa ter sido internalizado.

Acerca da temática das separações, Roussillon (2013) aponta que ela nos envia na direção da dialética do par presença/ausência, que comanda o trabalho de elaboração da experiência de separação. É a alternância da presença e da ausência dos objetos primordiais que vão instaurar os processos de diferenciação e, futuramente, de separação. O equilíbrio entre o par presença/ausência é que vai garantir, inicialmente, a experiência interna de continuidade psíquica, operação narcísica fundamental.

Nesse sentido, o problema da separação consiste na passagem da presença para a ausência, passagem do descolamento entre o investimento da representação 
interna do outro e sua percepção externa. Para que essa operação seja bem sucedida, existe um tempo próprio de maturação psíquica do bebê, mas existe também a necessidade de uma presença objetal "suficientemente boa", utilizando uma expressão winnicottiana, para que não haja o risco de, com a desaparição do objeto e de sua percepção, a representação do objeto ser "arrancada" junto com ele.

A partir destas contribuições, podemos nos perguntar como teria sido este início de diferenciação nos casos de automutilação. De que forma o par presença/ausência teria sido vivenciado? Como teria sido a qualidade da presença deste outro primordial? Poderíamos pensar em processos ocorridos nos primórdios, nos quais as descontinuidades entre sujeito e objeto teriam se dado de forma a prejudicar o sentimento de continuidade de existência destes sujeitos? Eles teriam sofrido vivências de descontinuidades desestruturantes no encontro com o outro, antes de terem seus limites - psíquicos e corporais - estabelecidos? Nesse sentido, poderíamos pensar na automutilação como uma defesa contra a (im)possibilidade de separação do outro?

\section{2 \\ Intersubjetividade e o sentimento de continuidade de existência nas automutilações}

A experiência interna de continuidade psíquica encontra-se indissociável da qualidade da presença materna e em relação direta com os processos de diferenciação e separação, explorados no tópico anterior. Se, nos casos de automutilação, o sujeito sente sua continuidade psíquica ameaçada por não se perceber diferenciado do objeto que o abandona, compreender de que forma esse sentimento de continuidade de existência é construído e mantido ao longo do tempo e do espaço será de extrema importância no presente capítulo.

Sabemos que, no início da vida, a questão da diferenciação se coloca atrelada ao terreno da intersubjetividade: para que o bebê se veja separado da mãe, será necessário passar por uma experiência de estar submetido ao mundo para começar, gradativamente, a ter consciência de que ele existe e de que está vivo, até chegar em um sentimento de ser uno e separado da mãe. Podemos sublinhar, com Golse (2006), que o acesso à intersubjetividade nunca está garantido e 
acabado, mas, ainda assim, há que pensarmos em um ponto de partida para esta criação.

Golse (2014) afirma ainda que o acesso à intersubjetividade tem relação direta com a operação de se tornar uma pessoa e a define como "o vivido profundo que nos faz sentir que o si próprio e o outro são dois” (p. 30, tradução nossa), que há uma diferença entre ambos. O autor coloca que esta temática é de extrema importância nas últimas décadas e ressalta o debate existente entre aqueles que defendem a emergência da subjetividade, dando mais ênfase ao interpessoal, e aqueles que colocam em foco primeiramente o intrapsíquico. O autor se posiciona como uma "terceira via", afirmando que a intersubjetividade é o que permite a descoberta do outro no registro interpessoal, possibilitando a construção do intrapsíquico. Juntamente com Roussillon (Golse \& Roussillon, 2010) e outras parcerias, o autor aposta na ideia de que o acesso à intersubjetividade ocorreria de maneira dinâmica e progressiva, valorizando a importância de ambos os campos, interpessoal e intrapsíquico, e caminhando na direção de uma intersubjetividade que dê suporte para o processo de subjetivação.

A subjetivação pode ser entendida como um caminho de descoberta de si mesmo como sujeito, ao mesmo tempo em que se descobre o outro como objeto e também como outro sujeito (Golse \& Roussillon, 2010). Nas palavras de Konicheckis (2018), “o sujeito começa sua existência a partir de lá onde ele ainda não é sujeito" (p. 75). Esse processo consiste em instaurar uma subjetividade a partir do encontro entre um ser ainda-não-sujeito e seu outro primordial, mediados pelo entorno. Contudo, no início da vida, o outro não é conhecido ainda como objeto totalmente destacado e diferenciado do bebê, de forma que podemos nos questionar sobre como o outro se apresenta para o bebê e se deixa conhecer por ele.

Quando pensamos na importância que o terreno da intersubjetividade adquire na compreensão do início da vida, ressaltamos que o nascimento do psiquismo encontra-se indissociável do nascimento do objeto (Golse \& Roussillon, 2010). No começo, o contato entre o bebê e o mundo ocorre através da sensorialidade e do ritmo, das continuidades e das descontinuidades que marcam suas experiências. Neste sentido, nos voltamos para estas dimensões com o intuito de compreender a forma através da qual o psiquismo se constrói no encontro com o outro (na qualidade da presença deste encontro) a partir das 
primeiras relações intersubjetivas de trocas, através do/mediado pelo sensorial e pelo ritmo.

Ressaltamos, com Cupa (2006), que a vida tem início através das sensações, de forma que a teoria de Anzieu dá enorme destaque para elas. Parafraseando Descartes, Cupa apresenta sua famosa frase reescrita, adotando a teoria de Anzieu: “eu sinto, logo existo" (p. 94, tradução nossa). Dessa forma, ela sublinha que a existência se encontra profunda e precocemente relacionada ao universo do sentir e das sensações, uma vez que só podemos conhecer o mundo externo mediado por elas.

Neste momento inicial do desenvolvimento, no qual predomina um eucorporal, Anzieu (1985/2000) atribui a existência do indivíduo ao sensorial, de forma que "nele não há representação da ausência, nem da ausência do objeto, nem da presença do indivíduo na mente do objeto ausente” (Mano, 2013, p. 99). Neste período, todas as experiências do bebê estariam atreladas às sensações despertadas em seu próprio corpo, despertadas pelo encontro com o mundo e seus objetos. Esta visão dos primórdios vai de encontro a outros autores que serão apresentados ao longo do capítulo, tais como Tustin, Haag, Konicheckis e Bick, que ressaltam o início da vida como uma espécie de "berço de sensações".

Em consonância com Aragão (2018), ressaltamos que o "início da vida é de certa maneira o reino da sensorialidade, da motricidade e do ritmo, ancorados no corpo e no contato com o outro" (p. 16). Esses campos que estamos descrevendo aqui já se encontram em atividade desde a vida uterina, primeiro capítulo de nossa história. De acordo com Aragão (2016), o feto vai recebendo estímulos táteis, sonoros, gustativos e olfativos que advêm do corpo materno e, com isso, vai se constituindo para ele uma rudimentar experiência sensorial de um primeiro outro, ainda não percebido como tal. Dessa forma, o feto já vive, no útero, breves experiências de descontinuidade que vão possibilitar um esboço de diferenciação entre ele e seu entorno.

No que diz respeito à precocidade das vivências sensoriais intrauterinas, Prat $(2007 ; 2010)$ ressalta que a pele possui desenvolvimento embriológico bastante aguçado, se tornando o primeiro órgão de transmissão de informações sobre o mundo para o bebê. Essa afirmação vai de encontro com a discussão já levantada no presente trabalho sobre a importância da pele como primeiro continente e fonte de comunicação com o mundo externo, transmissora das 
primeiras informações que apareceriam, apontando a existência de experiências "não-eu" no mundo do bebê. A singularidade do órgão pele, no que diz respeito à reflexividade, também possui papel importante intraútero, uma vez que a sensação de contato supõe e inclui o encontro com o outro e o ato de tocar um tecido diferente do nosso próprio causa sensações de ordens diferentes (tocar algo é diferente de se tocar).

As particularidades do tato levaram Prat (2007) a desenvolver a hipótese de que, no começo da vida, as primeiras experiências sensíveis são inscritas na dualidade da alternância entre estar em contato e estar sem contato, desde o útero materno. Essa hipótese traz à tona a dimensão do ritmo, indissociavelmente ligada à dimensão da pele e do toque, pois é através das continuidades e descontinuidades do toque (seja no ventre materno com as paredes uterinas, seja do bebê pós-nascimento) que alguma dimensão do "não-eu" pode começar a ser esboçada no bebê.

De acordo com Prat (2007), a ritmicidade dos encontros com aquele que um dia se tornará um outro sujeito já existe em um plano sensorial desde as origens, de forma que os primeiros contatos se inscrevem através dos elementos táteis na alternância do par contato/perda de contato. Podemos pensar que esse par é uma forma precoce de apresentação do par ausência/presença, responsável direto pelo sentimento de continuidade de existência que nos acompanhará ao longo de toda a vida. São estas experiências de descontinuidade vividas intraútero através dos domínios da sensorialidade que marcam as primeiras experiências de diferenciação entre mãe e bebê.

Discorrendo acerca da condição de prematuridade biológica do bebê humano, Freud aponta que "há muito mais continuidade entre a vida intrauterina e a primeira infância do que a impressionante cesura do ato do nascimento nos teria feito acreditar" (1926[1925]/1996j, p. 137), de forma que podemos expandir as descobertas de Prat (2007) sobre a vida intrauterina para a relação pós-natal e apostar no entrelaçamento do ritmo com a sensorialidade (em especial, o sentido do tato), na direção de compor nossa hipótese de trabalho sobre o início da vida e dos processos de diferenciação nos sujeitos que se automutilam.

No mundo do bebê, a sensorialidade e as sensações primam sobre o mundo representacional e o objeto se apresenta através das sensações. Durante o início da vida, o bebê só consegue perceber o objeto através de suas qualidades sensoriais. 
Konicheckis (2018) afirma que não podemos conceber experiências no bebê que se passem fora da sensorialidade e complementa:

Os órgãos de sentido são despertados e animados pelos objetos que lhes são exteriores. As primeiras experiências sensoriais do bebê não possuem significações imanentes. Elas são parcelárias, fragmentárias e descontínuas. O próprio da atividade psíquica consiste em ligá-las. Em sua origem, as satisfações, tanto quanto as inadequações, por falta ou por excesso, por parte dos adultos que se ocupam do bebê são experimentadas pelo bebê como uma experiência sensorial. Logo que ele percebe as sensações que o objeto produz em seu mundo íntimo, ele pode ter a impressão de estar em ligação com ele. (p.15)

Para Konicheckis (2002), a sensação se forma a partir do contato entre as superfícies das partes do corpo do sujeito e dos objetos presentes no mundo externo, fonte de surpresa, satisfação, excitação e, acrescentamos, por vezes, transbordamento. As sensações dão a ele não somente o sentimento da própria existência a partir do contato com o sensorial presente no mundo externo, mas também o sentimento de existência dos objetos do mundo externo e a continuidade de existência do entorno. Dessa forma, o contato com o sensorial fornece, ao mesmo tempo, a existência de si próprio e do mundo. Esta vivência permite ao bebê começar a estabelecer suas primeiras formas de identificação (Konicheckis, 2016).

Destacamos também os trabalhos de Frances Tustin e Geneviève Haag com o intuito de nos auxiliar na compreensão dos processos de diferenciação. Ambas destacam a importância do estudo da sensorialidade e do ritmo nas origens do psiquismo. Partindo da concepção freudiana de um eu-corporal, ambas ressaltam que os estados de sensações originais são de suma importância no desenvolvimento e no sentimento de continuidade de existência do eu. Enquanto Tustin se aprofunda nos conceitos e ideias acerca das sensações corporais geradas pelo contato do bebê com seu entorno, Haag se aprofunda nas primeiras etapas de formação do ego e ressalta a fonte sensorial e rítmica como fundamento do afeto e do pensamento.

Dessa forma, tomamos como base o estudo da sensorialidade e do ritmo nas origens do psiquismo para melhor compreender as práticas de automutilação. Tustin e Haag abordam formas muito primitivas de relações que se passam antes do processo de consciência de separação entre o par mãe-bebê e desenvolvem o tema da sensorialidade a partir da clínica do autismo. Apesar de não termos como foco no presente trabalho os quadros de autismo, acreditamos ser de suma importância a compreensão dos trabalhos das autoras, uma vez que a 
automutilação também traz à tona o componente sensorial, guardadas as devidas diferenças e singularidades psicopatológicas.

Segundo Konicheckis (2002), quadros como a automutilação e o autismo seriam responsáveis pelo aumento do interesse da Psicanálise sobre o tema da sensorialidade nas últimas décadas, uma vez que há um entrelaçamento considerável entre estas problemáticas. Para o autor, alguns quadros clínicos que vêm aparecendo com maior frequência, como as automutilações, são situações nas quais as referências à sensorialidade se encontram presentes de forma inegável. Tais quadros nos fazem um convite para nos debruçarmos sobre temáticas que fogem do campo representacional, colocando o corpo, os primeiros esboços do eu e o sentimento de continuidade de existência à frente da cena.

Tanto Tustin $(1977 ; 1984)$ quanto Haag (2018) consideram o predomínio das sensações como a base para a formação do eu, com base no eu-corporal freudiano. Neste momento, a continuidade de existência é garantida pela troca existente entre o bebê e seu entorno, que ocorre mediada pela sensorialidade e pelo ritmo. Em consonância com Konicheckis (2018), gostaríamos de ressaltar que o processo de subjetivação visa ao estabelecimento de um sentimento sensorial de continuidade da existência "nesse tempo onde, continuadamente, se produzem descontinuidades" (p. 75). Neste momento inicial, sujeitos e objetos psíquicos compreendidos como fazendo parte de uma relação objetal ainda não estão constituídos no bebê. Eles só se organizarão dessa forma a partir do desenvolvimento dos primeiros vínculos entre o bebê e seu objeto primordial.

Tustin (1990) descreve o eu primitivo como um fluxo de sensações, só podendo existir, inicialmente, através de um sentimento corporal de existência. Com base nos escritos de Winnicott, a autora afirma que, na primeira infância, a troca entre o par mãe-bebê tem como base a ilusão que "parece ser a de um fluxo e refluxo contínuo, rítmico" (p. 181). O sentimento de existência tem como suporte experiências sensoriais e rítmicas, que são vividas no corpo. Neste momento, a experiência psíquica está baseada nas sensações corporais, de forma que esses estados primitivos se apresentam como um "repertório de sensações relativamente descoordenadas que são mais sentidas que imaginadas" (Tustin, 1990, p. 175). Esse primeiro sentido de ser da criança, primeiro esboço de eu, pode ser localizado como eu-sensação (termo originalmente cunhado por Jonathan Muller). 
Haag (2018) aponta que, inicialmente, esses fluxos sensoriais encontramse clivados, de forma que o bebê só consegue perceber estímulos diferentes advindos de sentidos diferentes (audição, tato etc.), mediado por uma apreensão fragmentada da experiência. Cada sensorialidade se organiza de forma fragmentada inicialmente - clivada - e só é possível ter contato com o objeto em partes. Com base nos escritos de Meltzer, ela afirma que será necessário um “mantelamento" progressivo destes sentidos, na direção de compor um só objeto, percebido em sua totalidade, a partir da junção das sensorialidades clivadas. Para perceber o outro como diferente, afirma Golse (2018), o bebê deve, progressivamente, poder apreendê-lo por diferentes canais sensoriais simultaneamente, de forma a unir como uma totalidade as informações provenientes dos diversos fluxos sensoriais.

A ideia proposta por Tustin (1990) é de que, inicialmente, o eu-sensação seria experimentado na forma de líquidos e gases, uma vez que o bebê emerge de um meio líquido, sendo suas primeiras relações (alimentares e de excreção) permeadas justamente por líquidos e gases. Nesse momento, o sentimento de existência estaria atrelado a sensações gasosas e aquosas, de forma que as fantasias e terrores ilusórios relativos a essas vivências arcaicas podem se transformar em angústias avassaladoras na forma de sensação de ser derramado ou explodido, vazar através de buracos ou ser ameaçado por cascatas, redemoinhos e inundações, perdendo-se nestas sensações de aniquilamento do eu.

Na mesma direção, Mano (2013) defende a ideia de que, quando há um sentimento de existência, mesmo que precário, é porque já haveria, em algum nível, o surgimento de um eu. Em relação a este sentimento inicial precário de existência, Mano (2013) toma como base os trabalhos de Federn e Tustin para se referir ao "eu-rudimentar", primeira noção de eu pertencente ao sujeito, mesmo que possamos falar em termos de um "esboço" de eu, complementando a autora. Ela afirma que o eu-rudimentar seria, essencialmente, um eu-corporal, e que nesse estado "a existência é sensorial e, sem representação da ausência, tudo o que existe, existe no corpo" (p. 237).

Na mesma direção, Haag (2006) afirma que, nas etapas precoces do desenvolvimento, o sentimento de continuidade de existência é constituído através de percepções rítmicas que advêm da regularidade de comunicações sensoriais e emocionais com um objeto que ainda não é reconhecido como tal. Neste 
momento, ainda não há uma organização tridimensional que contenha o sujeito e o limite como unidade diferenciada das experiências do entorno. Para Haag (2018), o primeiro sentimento de existência nasce da percepção das ritmicidades sonoras e cinestésicas, desenvolvendo a hipótese do ritmo como primeiro continente. Tal aquisição consiste na interiorização progressiva das estruturas rítmicas a partir das trocas de experiências entre o par mãe-bebê.

Em seus escritos sobre o ritmo e a intersubjetividade na constituição psíquica, Victor Guerra (2018a) também afirma que o sentimento de continuidade de existência estaria vinculado às experiências rítmicas compartilhadas entre o par mãe-bebê. $\mathrm{O}$ autor atribui ao ritmo uma importância ímpar na construção da subjetividade, apresentando-o como organizador psíquico e temporal. O ritmo é composto por continuidades e descontinuidades, que, costuradas, formam o tempo e a história singular de cada um. Suas idas e vindas de acontecimentos dão ao sujeito a possibilidade de prever e conhecer possíveis situações, organizando as vivências desordenadas do bebê e trazendo um sentimento (ilusório) de segurança e confiabilidade. Nessa direção, o autor entende o ritmo como uma das primeiras formas de inscrição da continuidade psíquica, ao qual chamou de identidade rítmica.

Para que um primeiro sentimento de identidade seja formado e assegurado ao longo do tempo e do espaço, Guerra (2018b) afirma que o ritmo terá papel fundamental e organizador no fluxo desordenado de sensorialidades do bebê, que precisa ser integrado. Para o autor, os processos de subjetivação do bebê vão se dar através de duas formas: 1) compartilhamento da sensorialidade e do ritmo entre o par mãe-bebê; 2) compartilhamento das emoções entre o par mãe-bebê.

No que diz respeito à primeira forma, o autor cita as contribuições de Roussillon acerca do conceito de homossexualidade primária em duplo. Roussillon (2004b) nos fala da necessidade de haver um "compartilhamento estésico" entre o bebê e sua mãe, base para o primeiro e fundamental nível de investimento corporal: a sensorialidade. Ele descreve este momento como uma espécie de coreografia recíproca em que a mímica, a postura e os gestos de ambos serão ajustados, um correspondendo ao outro. Como um balé corporal, a comunicação se dará através de uma sintonia inconsciente e amodal, expressada por sensações compartilhadas através do ritmo que permeia ambos. A sintonia é 
recíproca, mas não simétrica, sendo necessário um ajustamento da mãe/ambiente às necessidades de seu bebê.

No que concerne à segunda forma de subjetivação do bebê, Guerra (2018b) se baseia nos escritos de Daniel Stern, especialmente sobre o conceito de sintonia afetiva. De acordo com o autor, a sensorialidade compartilhada forma um fundo sobre o qual é possível apoiar-se o compartilhamento das emoções entre o par mãe-bebê. Contudo, isso só ocorre com base em um ritmo adequado a este encontro. Tal ritmo leva em conta um ajuste materno que permita o respeito aos ritmos próprios do bebê e a cocriação de um ritmo comum, compartilhado por ambos. Roussillon (2004b) também propõe um nível de “compartilhamento afetivo", no qual o afeto surge a partir das produções sensoriais e deve se transformar em uma sintonia emocional entre o bebê e sua mãe. De forma similar ao "compartilhamento estésico", a mãe também ajusta seus afetos às necessidades do bebê, fazendo com que a harmonia seja mantida.

Ciccone (2018) também compartilha a ideia da importância do ritmo como estruturante da subjetividade no bebê. $\mathrm{O}$ autor afirma que a ritmicidade dos cuidados no início da vida, que levem em conta o ritmo próprio do bebê, instaura nele uma base de segurança. Se há a cocriação de um ritmo harmônico e próprio ao par, a ritmicidade dá ao bebê a ilusão da permanência e da continuidade de existência ao longo do tempo, oscilando momentos de continuidade com momentos de descontinuidade, culminando na segurança de seu sentimento de si. Tanto as continuidades quanto as descontinuidades são fundamentais para o psiquismo e a construção do sentimento de continuidade de existência. De acordo com Aragão e Zornig (2018), ambas são importantes, na medida em que as continuidades constituem a tessitura através da qual o psiquismo se vê existindo ao longo do tempo e as descontinuidades determinam os limites entre sujeito e objeto, protegendo-o de possíveis excessos do outro.

De acordo com Golse (2018), o acesso à intersubjetividade e o caminho rumo à subjetividade do bebê passam pela mediação desses ritmos compartilhados no contato entre o par mãe-bebê. Assim, o autor afirma que essa cocriação rítmica é "diálogo dos corpos e dos comportamentos e diálogos dos psiquismos, diálogos mútuos, mas certamente assimétricos” (p.11, tradução nossa). Diante de um compartilhamento que pressupõe dissimetria, o autor apresenta a metáfora da mãe como espécie de "maestro", chefiando a orquestra de diferentes ritmos e 
experiências do bebê. Nesse sentido, a mãe aparece como aquela que deve conseguir auxiliar o bebê a organizar os diferentes fluxos sensoriais recebidos de acordo com o estabelecimento deste ritmo compartilhado. A mãe desempenha papel importante ao mediar a sincronização polissensorial que abre caminhos para a futura concepção dos objetos enquanto diferenciados do bebê, colocando-o na seara da intersubjetividade.

As continuidades e descontinuidades no início da vida, advindas do ritmo comum entre mãe e bebê, constituem o processo de subjetivação do bebê e as sensações provenientes do mundo externo vão começando a formar, no sujeito, um núcleo íntimo e pessoal, responsável pelo sentimento de existência de si (Konicheckis, 2018). De acordo com Aragão e Zornig (2018), as continuidades presentes neste ritmo comum possuem estreita relação com a noção de identidade, com o sentimento de continuidade de existência,

\footnotetext{
que é correlato do estabelecimento de limites eu/não eu estáveis. Ambos estão intimamente relacionados, de tal modo que uma efração dos limites do eu interrompe o sentimento contínuo de existência. A construção da identidade depende da qualidade dos cuidados maternos primários e passa pela ilusão primeira de uma continuidade entre eu e não eu, para depois haver uma aceitação secundária de uma descontinuidade entre os dois. Será uma tarefa psíquica para a vida mantê-los ao mesmo tempo separados e ligados. (Aragão \& Zornig, 2018, p.7-8)
}

No caso das automutilações, apostamos na ideia de que o sentimento de continuidade de existência encontrar-se-ia prejudicado com a ameaça de perda do outro, uma vez que os limites entre sujeito e objeto estão confusos. Podemos nos perguntar o que acontece quando o ritmo de aparecimento do outro através das sensorialidades não é suficientemente bom, quando o ritmo próprio do bebe não é respeitado, quando o tempo de aparecimento do outro é anterior à possibilidade do bebê de criá-lo internamente enquanto objeto?

\section{3 \\ Rumo aos processos de diferenciação}

Retomando os conceitos de Tustin apresentados acima, podemos pensar que esse primeiro esboço de eu (eu-sensação) se encontra diretamente ligado a objetos, formas e sensações que fazem parte do mundo do bebê e são sentidas como partes do seu próprio corpo. Tustin (1990) ressalta que o senso primitivo de eu que é desenvolvido através das sensações ainda não seria tão bem delineado e 
separado do mundo externo. As sensações, ritmos e vibrações experimentadas em contato com o corpo da mãe são fundamentais para preservar a ilusão de unidade com a mãe, que virá a partir das sensações corporais do bebê despertadas pelo entorno, fundamental na compreensão do bebê de que a experiência que ele tem da mãe é contínua e ininterrupta. Aos poucos, ele vai se dando conta, gradativamente, de que existem dois sujeitos na relação, e não um.

O descolamento do eu e a progressiva noção de existência diferenciada do corpo materno só vai ser possível gradativamente através do contato com o entorno do bebê. A forma como ele vai desenvolver essa consciência do outro a partir do aparecimento gradual do não-eu será essencial para a construção do sentimento de si. Nesta direção, Tustin (1984) observa que a criança começa sua vida psíquica estabelecendo relações não com outros sujeitos percebidos como tal, mas com as sensações despertadas pelo seu entorno. Estas sensações corporais percebidas são sentidas pelo bebê como partes de seu próprio corpo e ganham o nome de objetos-sensação, uma vez que o bebê só vem a conhecer o mundo através da sensorialidade. Nas palavras da autora:

\begin{abstract}
Antes, parece haver um período imediatamente após o nascimento em que a criança reage ao mundo exterior em termos de seu próprio corpo e suas disposições internas. Isso estabelece sua imagem corporal como base para a identidade pessoal. Esse tempo primitivo é um estágio em que a experiência com "objetos-sensação" centradas no corpo e com a mãe experimentada como um "objeto-sensação" que constitui parte de seu corpo prepara o bebê para relacionamentos posteriores com objetos 'não-eu', (not-self), experimentados como separados de seu corpo e aos quais ele tem que aprender a se ajustar. (Tustin, 1984, p. 15)
\end{abstract}

Complementando com Konicheckis (2016), o objeto-sensação torna visível o que é criado na subjetividade do bebê quando há o encontro deste com os objetos do mundo a sua volta. Esse conceito ressaltaria tanto as sensações e as percepções quanto a existência dos próprios objetos dos quais elas emanam.

Contudo, antes de o bebê poder se relacionar em termos de objetosensação, Tustin (1990) nos fala da importância das formas na constituição psíquica, ressaltando que o bebê humano tem uma disposição inata para criar formas. Estas formas fariam referência às primeiras impressões do mundo, se originando das sensações corporais. Não se refere a formas geométricas, mas formas pessoais e idiossincráticas, que vão ter significado particular de acordo com a singularidade de cada um. O importante não seria o desenho da forma em si, mas a impressão que ela organiza. Em suas palavras: 
Essas "formas" primárias são provavelmente formações vagas de sensações. Elas tenderiam a compensar a aleatoriedade do fluxo de sensações que constitui o senso de ser primitivo da criança. (p. 99)

Assim como os objetos-sensação, as formas-sensação adviriam de sensações corporais sentidas como partes do próprio corpo, porém em um momento mais primitivo. Em consonância com Fontes (2001), ressaltamos que a experiência de se tornar humano tem relação direta com um fluxo primitivo de sensações não-coordenadas que passaria por uma “"produção de formas' até chegar a ter um corpo que as contenha" (p.25).

Retomando Tustin (1990), as formas-sensação, como foram chamadas, conteriam uma noção rudimentar de limite e de espaço, organizando a experiência vivida e propiciando uma transformação no espaço subjetivo, de forma a construir a espacialidade psíquica. Nessa direção, Mano (2013) chama atenção para a plasticidade encontrada neste conceito, uma vez que as formas-sensação seriam os "meios primários, elementares, por meio dos quais o infante cria o seu mundo" (p. 235).

Complementando as contribuições de Tustin, Mano (2013) sugere adotarmos o termo sentimentos-sensação para designar uma última descrição da autora ao lado das formas-sensação e dos objetos-sensação. Se as formas-sensação são as primeiras impressões das coisas e os objetos-sensação são formas associadas a objetos reais para que estes possam ser sentidos como partes do seu próprio corpo, os sentimentos-sensação seriam as primeiras "experiências infantis muito primitivas, nas quais 'sentimentos' são experimentados de forma física tátil como sensações de vários tipos" (Tustin, 1990, p. 69). Nestes casos, a emoção não seria um efeito das qualidades do objeto percebidas, mas das próprias sensações experimentadas.

Com o intuito de aprofundar a discussão, gostaríamos de trazer uma ideia de Fontes (2010), que afirma a existência de uma confusão inicial entre as principais emoções advindas de um funcionamento psíquico mais primitivo com sensações físicas corporais. Em sua coletânea sobre a temática da "Psicanálise do sensível", a autora também destaca o tato como sentido privilegiado nesse campo de trocas entre bebê e ambiente e afirma que, a partir do contato do bebê com objetos suaves e macios, ele vai entrando em contato com o sentimento da ternura. 
Dessa forma, o sentimento "ternura", inicialmente, é sentido, fisicamente, como tátil.

Pensando sob a ótica do presente trabalho, nós gostaríamos de ampliar esta compreensão para outras confusões de sentimentos iniciais que pode haver entre a emoção compartilhada e a sensação física experimentada. Nessa direção, complementamos que o sofrimento também pode ser vivenciado como uma emoção que aparece no corpo, na forma de sensação física. Se, inicialmente, a ternura é tátil, o sofrimento também pode ser. Esta forma de delinear a questão nos ajuda a pensar o campo das automutilações, uma vez que, a partir desta compreensão, podemos conceber que emoções difusas experimentadas pelos sujeitos que se automutilam podem ser transportadas para uma sensação física de machucar a própria pele, de forma que a emoção em si não pode ser percebida no momento do ato, mas o efeito de suas qualidades transforma-se nas próprias sensações físicas que serão experimentadas corporalmente.

A partir das contribuições de Tustin, entendemos que há um caminho gradual a ser percorrido para que o objeto possa enfim ser reconhecido como diferente do sujeito. No intuito de acessar a intersubjetividade e a diferenciação gradual, destacamos que a experiência do "não-eu" é crucial para o desenvolvimento do eu, desde que não seja vivida de forma antecipada ou abrupta. De acordo com Tustin (1984), isso acontece quando ainda não foi possível realizar a construção mental de uma mãe contínua no tempo e espaço, diferenciada e separada do bebê.

Com o intuito de evitar a percepção precoce do outro, Tustin (1984) sugere que este período do desenvolvimento seria marcado por uma fase anterior ao autoerotismo freudiano: a autossensualidade. Enquanto o autoerotismo diz respeito às fases da sexualidade infantil nas quais o sujeito obtém a satisfação de forma fragmentada a partir de partes do seu próprio corpo, sem recorrer a objetos externos (Freud, 1905/1996d), a autossensualidade protege o bebê do encontro prematuro com o "não-eu", de entrar em contato com o mundo, antes de se sentir devidamente integrado e diferenciado de seus objetos primordiais (Tustin, 1984).

No estado de autossensualidade, o bebê sente a mãe de forma autossensual, protegido pela ilusão de que ele e a mãe são partes do mesmo corpo, de forma que as partes do corpo da mãe com as quais ele tem contato são sentidas por ele como sendo partes de seu próprio corpo, mantendo a ilusão inicial de que 
dois fazem um. É nesta direção que Tustin (1990) afirma que "o ego primário é um ego autossensual" (p. 42), uma vez que a autossensualidade protege o bebê do encontro prematuro com o "não-eu". Neste momento, também não há o recurso a objetos externos e pessoas e coisas raramente seriam percebidas como separadas, com existência própria, sendo consideradas como uma extensão de suas próprias atividades corporais.

Tustin afirma que a autossensualidade é um momento de indiferenciação relativa, uma vez que não se caracteriza nem como anobjetal e nem como relações objetais precoces operando desde o início da vida, descritas pelos teóricos das relações objetais (Tustin, 1984, p. 15). A partir de leituras posteriores sobre teóricos que trabalhavam com a observação de bebês, como Trevarthen, Brazelton e Stern, Tustin (1990) coloca que "quando as primeiras diferenciações estão prosseguindo normalmente, é provável que haja momentos oscilantes de consciência de separação física da mãe, mesmo nos primeiros momentos de vida" (p. 41). Dessa forma, podemos compreender a ideia de uma indiferenciação "relativa", uma vez que há momentos, mesmo que breves, nos quais o bebê possui consciência de que ele não é fusionado completamente com a mãe.

Como complementação à noção de indiferenciação relativa no início da vida, estamos de acordo com Golse e Roussillon (2010), quando os autores mencionam um gradiente dinâmico e progressivo entre os estados de indiferenciação primitiva e de intersubjetividade. Os autores defendem a ideia de que o acesso à intersubjetividade não ocorre de forma "tudo ou nada", mas que é lentamente composto por oscilações entre momentos nos quais o bebê se sente indiferenciado da mãe, e outros momentos intersubjetivos, fugidios e breves inicialmente e ganhando mais consistência ao longo do tempo, nos quais o bebê suporta a vivência da mãe como minimamente diferenciada dele. De acordo com os autores, existiria um núcleo de intersubjetividade primária atuando desde os primórdios no bebê, mesmo que ele não seja percebido totalmente como tal.

Com base no conceito de nebulosa subjetiva de Myriam David, Roussillon (2010b) se refere aos momentos intersubjetivos do início da vida, nos quais o bebê encontra-se imerso em uma espécie de estados subjetivos não unificados. Nestes, haveria momentos nos quais o bebê vive um estado de confusão entre ele mesmo e a mãe, culminando em ilusões de fusão entre o par mãe-bebê; e momentos nos quais a mãe consegue ser percebida minimamente como um outro diferenciado, a 
ponto de o bebê poder estabelecer interações entre dois sujeitos. Contudo, estes momentos não durariam muito tempo, não garantindo ainda a existência de si e do outro como entidades totalmente separadas.

Destacando as contribuições de Roussillon (1999), gostaríamos de propor a reflexão de que a primeira noção de outro para o bebê só pode ser um outro especular, ou seja, suficientemente parecido com o bebê e só levemente diferente dele. É esta característica de refletir o outro que vai possibilitar o acesso à intersubjetividade como um processo que se desenvolve de forma lenta e gradual, mas precocemente marcado por momentos de diferenciação acessíveis a partir de suas interações.

A vivência da autossensualidade proposta por Tustin (1984), combinada com uma adaptação gradual da mãe, no sentido de se fazer presente como outro separado do bebê aos poucos, respeitando o ritmo do bebê em conhecer mais do mundo, é fundamental para a instauração do sentimento de continuidade do bebê. O fato dessa sintonia inicial se delinear na direção da mãe poder ser percebida aos poucos como parte separada e diferente do corpo do bebê permite a ele começar a guardar a presença da mãe em seu psiquismo, mesmo quando ela está ausente e, com isso, vão nascendo sujeito e objeto (Golse \& Roussillon, 2010).

Seguindo uma linha similar de pensamento, encontramos a hipótese winnicottiana de objeto encontrado/criado: o objeto é criado alucinatoriamente e encontrado no campo da percepção. Esta coincidência dos processos abre ao campo da ilusão, para o qual será fundamental refletir sobre a importância da presença do objeto.

Pensando a respeito do desenvolvimento emocional primitivo do bebê, Winnicott (1953/1975a) nos apresenta o que chamou de momento da ilusãodesilusão. Segundo o autor, para que este processo seja satisfatório, será necessário que, de início, a mãe se adapte ativamente às necessidades do bebê e, aos poucos, de acordo com a possibilidade deste bebê tolerar frustrações, vá se desadaptando gradativamente. A adaptação inicial quase completa ao bebê dá a ele a ilusão de que o ambiente é criado e controlado de forma onipotente por ele.

No início da vida, um bebê se dá conta de que há algo que poderia diminuir sua tensão pulsional. Ele não sabe exatamente do que se trata, o que deve ser criado, mas sente que algo pode ser feito. Neste momento, a mãe aparece e, se devidamente adaptada ao bebê, compreende aquele chamado e encontra uma 
resposta que é sentida pelo bebê como satisfatória. Ou seja, há uma sobreposição entre o ato materno de suprir uma necessidade do bebê e o que ele poderia conceber como necessidade. Nesse sentido, a ilusão habita uma área intermediária entre interno e externo, entre o que é objetivamente percebido e o que é subjetivamente concebido - a área do transicional.

O campo da ilusão traz à tona a coincidência entre os processos de criação do bebê em sua onipotência e controle mágicos e a devoção materna em suprir alguma necessidade que ela acredite estar presente no bebê. Nas palavras de Winnicott (1953/1975a, p. 26), “a mãe coloca o seio real exatamente onde o bebê está pronto para criá-lo, e no momento exato".

O papel desempenhado pela ilusão é fundamental para todo o desenvolvimento emocional posterior da criança, uma vez que essa adaptação suave à realidade é o que permitirá que ela mantenha uma relação mais saudável com as barreiras entre interno e externo, objetivo e subjetivo, fantasia e realidade. Complementando, Roussillon (2012b) chama a atenção para a presença do objeto no conceito de ilusão winnicottiano, uma vez que nos fala sobre a importância da coincidência entre os processos do bebê e a resposta ambiental.

Nesta direção, podemos pensar que este processo só ocorre se há uma sintonia entre mãe e bebê neste momento inicial. É apenas de acordo com a resposta da mãe que a ilusão criada pelo bebê pode se tornar percepção a partir de uma sensação primitiva vivida pelo bebê (Roussillon, 1999).

Quando o ambiente surge de forma prematura para o bebê, rompendo a ilusão de onipotência de criação do mundo winnicottiana e dilacerando a unidade fictícia sugerida por Tustin (1984) entre o corpo do bebê e o corpo da mãe, haveria um rompimento da autossensualidade protetora (que fazia com que o mundo aparecesse como criação e parte do bebê), culminando no aparecimento precoce do não-eu. Essas vivências prejudicam os processos de diferenciação, não respeitando o ritmo de elaboração do bebê e deixando marcas que podem ressoar por toda a vida do sujeito.

Tendo em vista que nos quadros de automutilação estão em jogo dificuldades com separações que não podem ser vividas como bem delineadas entre dois sujeitos diferenciados, podemos nos perguntar se teria havido vivências desestruturantes de descontinuidade sentidas como separações antes da compreensão de que aquele outro não era parte dele próprio? Teria o ritmo entre o 
par mãe/bebê se passado de forma desarmônica, não respeitando as condições de possibilidade do bebê de construir um momento de ilusão e criação do objeto antes que o mesmo fosse apresentado para ele como outro minimamente diferenciado?

\section{4 Descontinuidades nas origens da automutilação}

Discorrendo sobre a importância dos processos de subjetivação, Golse (2014) destaca alguns episódios nos quais as vivências de diferenciação não ocorrem de forma minimamente satisfatória, respeitando o ritmo próprio do bebê, aos quais nomeia de violências da diferenciação. Descartando deste cenário o caráter constitutivo da violência, trabalhado por autores como Laplanche e Aulagnier, o autor faz referência a casos nos quais os processos de diferenciação começam a ocorrer muito precocemente, de forma rápida ou brutal para o bebê. Nesses casos, o objeto começa a se fazer presente em tempo anterior ao das possibilidades de elaboração da percepção da diferença pelo bebê e o não-eu surge como fenômeno imprevisível e dilacerante.

Retomemos a contribuição de Tustin (1984) de que no estado inicial de autossensualidade ainda não há a concepção de um objeto distinto, separado do bebê. Neste estado, encontramos uma vivência de ilusão de que ele e a mãe são partes do mesmo corpo, as partes do corpo da mãe com as quais se têm contato são sentidas pelo bebê como sendo partes de seu próprio corpo, preservando o bebê do contato precoce com os objetos. Se vivências de separação ou descontinuidade excessiva com o objeto primordial ocorrem recorrentemente, transbordando as capacidades de paraexcitação do par mãe-bebê, os processos que se instauram no bebê não são da ordem da separação entre sujeito e objeto, como já explicitamos no início do presente capítulo, mas uma sensação de aniquilamento que transborda o bebê. Se o outro primordial é sentido como parte dele próprio, as vivências de descontinuidade deflagradas pelo desaparecimento do outro têm proporções catastróficas de perda de si mesmo no bebê.

Para construir o raciocínio de um eu que se perde juntamente com os objetos nesta etapa da autossensualidade, Tustin (1984) recorre aos escritos de Winnicott (1963/1983), que também localiza situações nas quais descontinuidades 
precoces entre o par mãe-bebê podem ter como significado a sensação da perda de partes do corpo do próprio sujeito:

Por exemplo, a perda pode ser de certos aspectos da boca, que desaparece do ponto de vista do lactente junto com a mãe e o seio, quando há uma separação em uma data anterior àquela na qual o lactente alcançou um estágio do desenvolvimento emocional que propiciaria a ele o equipamento para lidar com a perda. A mesma perda da mãe alguns meses mais tarde poderia ser uma perda de objeto sem este elemento adicional da perda da parte do sujeito. (Winnicott, 1963/1983, p. 200)

Dessa forma, ressaltamos que vivências precoces e abruptas de descontinuidades neste período inicial da vida resultam em rompimento repentino do sentimento de ilusão (Winnicott, 1953/1975a). Este caminho da ilusão à desilusão deve ser apresentado aos poucos, de acordo com as capacidades gradativas do bebê de entrar em contato com a frustração advinda do mundo exterior e das vivências do não-eu.

Na mesma direção, Tustin (1990) ressalta que, nos casos em que há vivências de separação antes de o bebê estar preparado para se relacionar com o mundo em termos de não-eu, este é experimentado como aterrorizante. A autora descreve uma cena emblemática com base em um de seus casos clínicos, na qual um bebê que faz contato precocemente com a ideia de que o mamilo da mãe em sua boca durante o momento de amamentação não seria parte de sua própria boca. Essa percepção culmina no fato de o mamilo se destacar do amálgama sensorial "boca-envolvendo-mamilo", que ela chama de "cacho-de-sensações". A autora ressalta o temor que assola a criança a partir da percepção precoce do mamilo como não-eu na medida em que, uma vez que o mamilo deixa de fazer parte da ilusão de habitar o corpo da própria criança, ele pode vir a desaparecer a qualquer momento, levando todo o alimento e afeto com os quais se deliciava.

$\mathrm{O}$ contato precoce com o não-eu resultaria na criança em um medo de aniquilamento similar ao medo do colapso winnicottiano. Recordemos que Winnicott (1967/1975b) afirma que o afastamento da mãe por um tempo maior do que o bebê é capaz de suportar nesses momentos iniciais da vida é vivido por ele como sentimento de aniquilação, como se nem a mãe e nem ele existissem mais. A partir da percepção precoce do mamilo como parte não-eu, a criança perde com ele a ilusão de um corpo que cria e controla o mundo externo, ficando vulnerável e a mercê de um outro que surge como ameaçador de sua própria existência. 
A partir das últimas contribuições apresentadas sobre a precocidade do aparecimento do não-eu, gostaríamos de complementar a hipótese referida anteriormente no presente capítulo. Se os fenômenos de automutilação constituem uma defesa frente à ameaça de perda do outro, podemos pensar que, nestes casos, teria havido vivências precoces de descontinuidade que irromperam a capacidade ilusória do bebê em um momento em que o objeto primordial era sentido como uma extensão do próprio corpo do sujeito. É nesta direção que a perda do outro é sentida como ameaça de aniquilamento.

$\mathrm{Na}$ mesma direção, Ciccone (2018) afirma que separações, perdas e rupturas constituem descontinuidades inevitáveis na vida de um bebê, mas que não devem exceder certo tempo. "O objeto não pode desmentir a promessa do encontro e o encontro deve acontecer de maneira rítmica, num ritmo que garanta a continuidade" (p. 19). Com base nos escritos de Winnicott (1974/1994), passado esse tempo máximo, a ausência se transforma em vazio.

Sobre a importância do ritmo, Golse (2001) sublinha que o par separação/diferenciação encontra-se intrinsecamente ligado ao par presença/ausência, de forma que o ritmo surge como elemento fundamental na compreensão dos processos de diferenciação. Ciccone (2018) afirma que $a$ ritmicidade organiza a experiência de separação no desenvolvimento do bebê, ajudando a curar a fratura que esta produz. A ritmicidade permite a antecipação de novos elementos, dando ao bebê não apenas a capacidade de desenvolver a ideia de permanência no tempo (de si e, posteriormente, do objeto), mas auxiliando na própria capacidade de criação winnicottiana do objeto encontrado/criado.

Se estamos de acordo com a afirmação de que o ritmo organiza a separação, podemos supor que um ritmo não gerenciado leva a falhas nos processos de separação/diferenciação. Nas palavras de Ciccone (2018):

\footnotetext{
quando as disritmias são não temperadas, desorganizadoras, e o bebê fracasse ao encontrar uma continuidade nas experiências corporais, nas sensações, e fracasse em reestabelecer uma ritmicidade, em se apegar a movimentos rítmicos, então ele se desorganizará, se agitará, mergulhará numa experiência informe e confusa. (p. 22)
}

Sobre experiências rítmicas não subjetivadas, Roussillon (2006b) ressalta a disritmia como figura arquetípica dos desencontros precoces. $\mathrm{O}$ autor considera o ritmo harmônico coconstruído entre o par mãe-bebê essencial para a constituição psíquica do bebê. Nesses casos, afirma que o sofrimento advém do não-respeito 
deste ritmo, deixando falhas que ficarão registradas não sob o domínio da representação, mas da apresentação do corpo.

No campo das automutilações, podemos compreender, a partir das hipóteses apresentadas, que haveria excesso de descontinuidades, vivido no momento primevo de instauração dos processos de diferenciação entre sujeito e objeto, culminando em falhas rítmicas entre o par mãe-bebê. Essas falhas constituem uma dimensão de disritmia precoce, deixando em evidência os desencontros e as desarmonias experimentadas pelo bebê em termos de apreensão gradativa do mundo. Devido à falta de sintonia do par, o outro enquanto não-eu teria surgido de forma precoce e/ou abrupta para o bebê, que ainda não tinha elementos para se ver diferenciado.

Essas vivências levam a uma dimensão arcaica da automutilação que denuncia as disritmias que compuseram o par sujeito e objeto primordial. Ecos advindos dos primeiros processos de diferenciação surgem em diferentes momentos da vida, em diferentes situações de perda do outro. Nesses casos, separar-se de uma figura importante na adolescência ou na vida adulta (que pode ser o próprio objeto primordial ou alguém que ocupe esse lugar de importância) pode vir a significar a não existência, como se o eu fosse se perder junto com o outro que parte.

Assim como a hipótese já apresentada de Prat (2007) afirma que as primeiras experiências sensíveis na direção de uma diferenciação são inscritas na dualidade da alternância entre estar em contato e estar sem contato, desde o útero materno, podemos destacar que o início da integração narcísica e do reconhecimento dos limites entre sujeito e objeto é proporcionado pela experiência de um ritmo seguro adquirido entre o par mãe-bebê, que só será possível através de um contato corporal, que passa pelo "pele-a-pele" (Anzieu, 1985/2000). O estar em contato com os ritmos da mãe através de suas peles dá ao bebê, desde o útero, a sensação de que já existem momentos de diferenciação, mesmo que ínfimos.

Assim como Winnicott (1967/1975b) e Tustin (1984; 1990) chamam atenção para os problemas advindos das vivências de descontinuidades maternas para o bebê, Prat (2010) afirma que a ausência precoce do outro nos primórdios da subjetivação pode ser vivida pelo bebê como um "arrancamento" de peles, deixando-o sem contato, vulnerável a buscar recursos de estimulação sensorial 
como forma de sobrevivência. Como uma espécie de busca pelos traços sensoriais dessa pele comum perdida, que representaria a ausência do objeto primordial, pode-se pensar em uma dimensão deste fenômeno nos casos de automutilação. Nestes, o sujeito procuraria, na sensação de machucar a pele, o estado de estar em contato, garantindo sua existência momentânea e sua integridade narcísica, apesar das descontinuidades externas.

Dessa forma, voltamos a propor a importância das trocas através das peles na construção da subjetividade do bebê e retomamos a noção de sua própria pele como envelope de possível contenção das diferentes sensorialidades. A pele representa um primeiro lugar de contato entre o bebê e o outro, sentido através das variações rítmicas uterinas (Prat, 2010). Ela também será o recurso através do qual os sujeitos que se automutilam buscam recuperar ou preservar uma possível perda de integridade narcísica e do sentimento de continuidade de existência.

Retomando a temática da pele e evocando as contribuições de Esther Bick (1968), a autora apresenta em seu clássico artigo, intitulado The experience of the skin in early object-relations, a tese de que nas mais primitivas formas de relação de objeto, as partes da personalidade do bebê são sentidas como não tendo ligações entre si e devem ser integradas a partir da experiência da pele. Em uma proposta similar ao que temos discutido no presente capítulo acerca das primeiras experiências do bebê como sensorialidades fragmentadas que só podem ser vividas "uma a uma", a autora afirma que estas partes não integradas da personalidade são sentidas de forma fracionada, sendo necessário que "algo" venha assumir o lugar de função de contenção para uni-las narcisicamente. Para ela, é a pele que fará o papel de integrar as partes dispersas, se configurando como continente dessas sensorialidades, demarcando um território único, fechado e diferenciado de outros sujeitos e objetos.

Nesse sentido, podemos pensar que a pele é o órgão que liga diferentes sensorialidades vindas dos órgãos dos sentidos variados, de forma a possibilitar uma experiência de integração física, conforme sinalizado anteriormente, mas isso só será possível a partir de uma experiência rítmica compartilhada. A pele também possui dupla face, com camadas distintas, que comunicam e separam o interior do exterior. A pele envolve todo o corpo e o delimita, ao mesmo tempo em que é flexível e plástica. Por último, destacamos que a sensibilidade tátil é reflexiva, que 
antecipa e prepara para outras reflexividades alcançadas com o desenvolvimento do eu (Mano, 2013).

Nesta direção, ressaltamos as contribuições de Paul Lacombe (1959), psicanalista pioneiro na temática da pele nos processos de constituição psíquica. No artigo intitulado $\mathrm{Du}$ rôle de la peau dans l'attachement mère-enfant, o autor investiga a importância do vínculo existente entre mãe e bebê possibilitado pela experiência de troca entre ambas as peles e suas consequências para a constituição psíquica do sujeito. $\mathrm{O}$ autor apresenta alguns germes da discussão posterior que Anzieu vai propor acerca da pele e do início da vida. Ele chama atenção para a importância fundamental da pele nas primeiras relações objetais e para a forma através da qual uma história infantil inicialmente conturbada entre o par mãe-bebê traz graves questões na vida adulta dos pacientes, dentre elas episódios de automutilação e crises ligadas a separações.

Retomando a discussão do capítulo anterior acerca da problemática da pele na automutilação, seguimos destacando, em consonância com Roussillon (2007), que habitar a própria pele diz respeito à questão da diferenciação eu/não-eu. Discorrendo sobre as contribuições de Anzieu, Mano (2013) ressalta que quanto mais bem estruturado o eu-pele do sujeito, maior a segurança narcísica advinda deste momento inicial e maior a possibilidade de independência conquistada por ele, de vir a ser dono da própria pele. Dificuldades nestes momentos de constituição podem vir a prejudicar o processo de diferenciação, mantendo o indivíduo "preso" à pele e ao corpo do outro, ou melhor, mantendo o outro preso e misturado à sua própria pele e corpo.

Neste sentido, o ataque à pele nas automutilações representa uma tentativa paradoxal de contenção, uma vez que há na sensorialidade uma promessa de integração do eu, assim como acontecia nos primórdios das experiências do eu. Segundo Konicheckis (2016), o campo da sensorialidade mantém “os vínculos entre psique e soma, constitutivos do eu-corporal, suscetíveis de acolher, integrar e subjetivar as experiências psíquicas” (p. 1020, tradução nossa). Esses elementos trazem o sujeito para o tempo presente, lembrando-o de que ele permanece vivo e integrado, sem ter sido aniquilado pela partida do outro.

No caso das automutilações, percebemos que este sentimento de continuidade de existência se encontra prejudicado. Para dar conta desta vivência de ameaça de aniquilamento, uma saída radical na automutilação seria buscar uma 
espécie de contenção, que é alcançada através do ato de ferir o próprio corpo, encontrando alívio temporário em uma atividade de convocação da sensorialidade com o intuito de recuperar a integridade narcísica ameaçada. Se a continuidade de existência é garantida inicialmente pelas trocas rítmicas existentes entre o par mãe-bebê, mediadas pela sensorialidade, o sujeito que se automutila recorre a esse efeito de integração que adviria do encontro com o sensorial.

$\mathrm{Na}$ direção destes questionamentos, Konicheckis (2016) afirma que as sensações atestam a existência de uma realidade externa e, a partir disso, podem garantir momentaneamente para o sujeito um sentimento de continuidade de existência. No caso das automutilações, percebemos que este sentimento de continuidade de existência se encontra prejudicado, de forma que o recurso ao sensorial é evocado como forma extrema de recuperar este sentimento. A sensação de alívio encontrada nestes atos tem relação direta com este tempo no qual a existência está garantida. A automutilação permite que o sujeito recupere sensações advindas de elementos que são ao mesmo tempo repetitivos, porém novos e também formadores da vida psíquica. Estes elementos sensoriais recuperados e criados pelo ato surgem como plano de fundo através do qual podem surgir novas simbolizações. 


\title{
4 \\ A dimensão do arcaico e suas repercussões para a clínica da automutilação
}

\author{
Por muito tempo achei que a ausência é falta. \\ E lastimava, ignorante, a falta. \\ Hoje não a lastimo. \\ Não há falta na ausência. \\ A ausência é um estar em mim. \\ E sinto-a, branca, tão pegada, aconchegada nos meus braços, \\ que rio e danço e invento exclamações alegres, \\ porque a ausência, essa ausência assimilada, \\ ninguém a rouba mais de mim. \\ Carlos Drummond de Andrade
}

Até o momento, apresentamos a ideia de que a automutilação comporta sempre duas dimensões, que se sobrepõem: uma dimensão edípica, contendo relação direta com a problemática da adolescência e seus remanejamentos e revivescências corporais, e uma dimensão arcaica, que diz respeito a problemáticas mais narcísicas do início da vida, de construção do eu-corporal e da dimensão do sensorial e do ritmo. Viemos construindo, ao longo dos capítulos anteriores, um percurso que deixa em evidência as bases para pensarmos na dimensão arcaica presente nas automutilações. Esta dimensão diz respeito ao campo do pré-verbal, das sensações, do ritmo compartilhado e dos momentos ilusórios de indiferenciação entre o par mãe-bebê.

Conforme ilustrado ao longo da tese, esses elementos arcaicos dos primórdios sensoriais não estão perdidos em uma memória que ficou "no passado", formada por acontecimentos que pertencem a uma linha do tempo cronológica, mas fazem-se presentes no atual da vida de todos os sujeitos. Eles estão presentes e se fazem presentes nas formas de se relacionar com os outros sujeitos, ecos de nossas primeiras relações intersubjetivas.

Nos quadros de automutilação, essa dimensão arcaica se faz presente especialmente na clínica, demandando do analista uma disponibilidade polifônica complementar ao campo do verbal, permitindo que ele "escute" também elementos que fazem parte de uma escuta pré-verbal e afetiva, complementando nossas ferramentas de trabalho na clínica da automutilação. Com o intuito de melhor exemplificar de que forma esta dimensão arcaica da automutilação surge 
na clínica, apresentaremos três fragmentos de casos atendidos pela autora, entrelaçando as discussões do presente trabalho com a prática clínica.

\section{1 \\ Ressonâncias do arcaico na clínica da automutilação}

Conforme sinalizado anteriormente, a automutilação comporta uma dimensão arcaica, de vivências relacionadas a problemáticas narcísicas e a construção da subjetividade. Essa dimensão faz referência a períodos anteriores à aquisição de linguagem pela criança, quando a operação de diferenciação eu/nãoeu está em pleno desenvolvimento. De acordo com Roussillon (2010b), as problemáticas deste período estão ligadas aos processos de simbolização primária, próprios aos momentos de constituição psíquica e dos primórdios da vida do bebê. $\mathrm{O}$ autor considera o estudo destes processos como fundamental para nos auxiliar a melhor compreender diferentes psicopatologias que surgem no período da adolescência e/ou da vida adulta, especialmente as que apresentam uma dimensão narcísica acentuada, como é o caso das automutilações.

No que diz respeito à problemática das automutilações, defendemos, ao longo da tese, a ideia de que seria possível encontrar nestas condutas uma leitura privilegiada de aspectos infantis mais arcaicos, anteriores à problemática edípica, relacionados ao momento de desenvolvimento do bebê. Com base nos escritos de Ciccone $(2011 ; 2012)$, sustentamos um aprofundamento acerca da temática do arcaico para sublinhar que a forma de apreensão do mundo e as marcas deixadas pela nossa experiência enquanto bebês não desaparecem, nem se transformam completamente com o passar do tempo, na direção da vida adulta. A maneira de se relacionar com o mundo permanece lado a lado com outros modelos de compreensão de si mesmo e dos outros.

Neste cenário, podemos entender as automutilações como uma via atual através da qual algumas vivências da ordem do arcaico se apresentariam, em um registro que conjuga, ao mesmo tempo, passado e presente. Esta forma de compreensão do arcaico coloca em jogo um curto-circuito no tempo, de maneira que formas bastante primitivas de se relacionar com o entorno surgem na superfície de relações agora muito mais complexas. As automutilações podem nos dar notícias dos primórdios da constituição psíquica desses sujeitos, trazendo à 
tona uma dimensão corporal de sentimentos e formas de se relacionar vividos nestes primeiros momentos de vida, cercado por diferentes sensorialidades.

De acordo com Anne Brun (2014a; 2014b), desde os tempos de Freud já existem os fundamentos para a criação de uma teoria do arcaico na vida psíquica. $\mathrm{O}$ aumento de casos que têm problemáticas narcísicas em primeiro plano teria levado os psicanalistas a se confrontarem com outras dimensões para além da linguagem verbal, permitindo que eles colocassem em primeiro plano a importância do corpo, do sensorial e da motricidade na clínica, chegando aos domínios do que Roussillon (1999) chamou de processos de simbolização primária.

Dessa forma, podemos pensar que a mudança na clínica psicanalítica em geral, mais especificamente na clínica das automutilações, seria da ordem da escuta e da compreensão do analista, que passaria a ouvir conteúdos distintos, deixando claro que há algo de uma comunicação não verbal que escapa do paciente que agora estaria disponível, sendo impossível ignorá-lo. Neste sentido, o conteúdo verbal que o paciente comunica na análise passa a não ser mais entendido como a totalidade de material ao qual o analista deve se atentar, levando também em consideração outros elementos.

Neste sentido, Brun (2014a; 2017) afirma que as formas primárias de simbolização reenviam o sujeito ao registro do arcaico, que é diferente de buscar uma origem localizada em um tempo estanque primevo. A autora chama atenção para a dupla etimologia da palavra arcaico: se, por um lado, ela significa "começo", designando as primeiras relações da criança com seu entorno, ela também significa "princípio", designando a dimensão organizadora e estrutural das formas primárias de simbolização. Nas palavras da autora:

\footnotetext{
O arcaico designa, na Psicanálise, os aspectos do psiquismo organizados no passado mais remoto, que serão retomados e reorganizados ao longo de toda a vida. O conceito de arcaico reenvia à construção dos vínculos com o objeto e aos processos de diferenciação com este objeto, contudo, o arcaico continua também presente ao longo de todo o tempo em cada um de nós. O arcaico não se confunde, então, com o originário, mas constitui uma primeira expressão dele. (Brun, 2014a, p. 4, tradução nossa)
}

Nesta direção, a autora faz uma ressalva que abre espaço para pensarmos acerca da temporalidade psíquica: não é porque chamamos estes processos iniciais de formas primárias de simbolização que eles estão restritos a uma temporalidade das origens. Na realidade, estas formas, assim como a dimensão do arcaico, 
encontram-se presentes na vida psíquica de todos os sujeitos e durante toda a sua vida.

O conceito de arcaico apresentado neste subtópico traz à tona questionamentos acerca da temporalidade na clínica psicanalítica, uma vez que não importa a idade do paciente, não temos como acessar estas bases originárias. Mesmo que a psicanálise seja aplicada a sujeitos cada vez mais jovens, como vemos na clínica com bebês, o arcaico não se manifesta de forma direta e observável, só podendo ser acessado a partir de seus efeitos ao longo do tempo. É sob esse arcaico, que perverte a linha do tempo cronológico ao mesmo tempo em que se configura enquanto elemento de potência na clínica, que gostaríamos de lançar luz na temática das automutilações.

André Green (1982/1990) aponta que o nascimento do psiquismo é marcado por um período arcaico, que remete às origens de nossa existência. Todavia, o autor amplia a discussão temporal trazida pelo conceito de arcaico afirmando que a metáfora de uma possível arqueologia psíquica a ser realizada pelo analista na direção de um passado que ficou imóvel, congelado em tempo primevo, aguardando para ser descoberto e reconstituído posteriormente, não faz sentido, uma vez que chegar às origens do psiquismo, além de ser uma ilusão, não traria os benefícios esperados. O autor ressalta que o material que é trazido para a superfície do psiquismo através do trabalho de interpretação e associação livre não pode ser considerado o testemunho fiel da pré-história do sujeito, sendo essa maneira de ver o tempo como estanque e imutável uma ideia ingênua de pensar que o passado se conserva em sua forma originária.

O arcaico não está no passado esperando passivamente sua descoberta, mas está sempre presente, se manifestando em nós no cotidiano de todos os dias. Partindo desta constatação, Green (1982/1990) sugere que, ao invés de seguirmos em uma busca inócua na direção de um passado estagnado e ilusório, tentemos o caminho inverso: encontrarmos o passado que se apresenta no presente, no après coup de enésimos "segundos tempos" aos quais temos acesso em diferentes momentos da vida. $\mathrm{O}$ autor sugere acrescentarmos essa dimensão do après coup ao arcaico, com o intuito de destacar que a única forma de falar do arcaico é levando em consideração esta forma diferenciada de abordar o registro temporal.

Importante abordarmos essa noção freudiana de après coup (Nachträglichkeit) para melhor compreensão da discussão proposta acerca da 
temporalidade do psiquismo. Tal ideia está intrinsecamente ligada à teoria do trauma em dois tempos, apresentada por Breud e Freud (1895/1996) no início de seus escritos. Em uma primeira cena, a criança é convidada sexualmente por um adulto, sem que ela compreenda o que ocorreu como excitação sexual genital. A segunda cena, normalmente de caráter anódino, ocorre a partir da puberdade e evoca a primeira por traço associativo, transformando seu valor posteriormente, pois agora a excitação sexual já pode ser vivida enquanto tal (Laplanche \& Pontalis, 1967/1970).

De acordo com Jacques André (2008), Freud, ao usar o termo Nachträglichkeit, nos apresenta uma noção de tempo bastante diferenciada daquela proposta pela flecha comum de passado, presente e futuro, com uma única direção a ser percorrida. O conceito de Nachträglichkeit faz cair por terra o tempo linear, apresentando um tempo que condensa paradoxos: une "a simultaneidade, a solidariedade, a confusão de um passado-presente e de um presente-passado. O efeito de après-coup ignora a contradição" (p. 140).

Ressaltamos que, a partir desta perspectiva, a mudança está no fato de que a recordação do sujeito não diz respeito à cena exata ocorrida na realidade, mas ao acesso a um material transformado e processado psiquicamente, que pode continuar a ser modificado ao longo do tempo. Dessa forma, uma experiência passada pode ser ressignificada em um contexto de experiência atual, assim como uma experiência atual deve levar em consideração vivências e acontecimentos do passado (Cidade \& Zornig, 2016). São esses elementos e possibilidades de complexificação temporal que fornecerão as bases para uma melhor compreensão dos elementos sensoriais e rítmicos na clínica da automutilação, de forma que quando ela se torna mais dinâmica e potente no que diz respeito a possíveis ressignificações de materiais advindos do passado, assim como do presente.

Sobre a temporalidade, Roussillon (2010b) aponta que, nos momentos iniciais da vida, o bebê não conhece o conceito de tempo linear, de forma que as experiências passadas neste período tendem a ser vividas como eternas e as não experiências como um grande vazio, uma vez que o próprio sentimento de existência só ocorre através das sensações e do contato com o outro. Nesse sentido, o bebê "vive em uma espécie de instantaneidade que, ao mesmo tempo, é uma eternidade" (p. 100, tradução nossa). 
Essa discussão do tempo complementa as vivências de aniquilamento apresentadas nos quadros de automutilação, uma vez que os sentimentos de vazio e não-integração tomam conta da cena. A dimensão arcaica da automutilação nos remete a essa espécie de "tempo além do tempo", no qual as vivências do par mãe-bebê excederam as capacidades de integração egoica, lançando o sujeito em um sentimento de eterno vazio, de não-existência.

Sobre a temporalidade na clínica, Ciccone (2008) propõe uma diferenciação que considera existir entre os conceitos de infantil e de arcaico. Para ele, o arcaico estaria ligado ao começo da vida, mais especificamente aos modos de relação estabelecidos pelo par mãe-bebê. Podemos compreender o arcaico como a forma através da qual as experiências primárias deixam marcas sob a forma de angústias, de modos de defesa e tipos de relação com o mundo, mesmo se o desenvolvimento modificar, recobrir, apagar ou transformar consideravelmente essas primeiras experiências, que acabam se tornando perdidas. Dessa forma, o arcaico faz referência às experiências precoces que deixam sua marca indelével, apesar de não podermos rastreá-lo precisamente.

Já o infantil diria respeito a um campo mais amplo, que contém tanto o arcaico quanto as experiências próprias ao "momento bebê" e ao "momento criança" (pré e pós-verbal), de forma que o campo do infantil englobaria o arcaico junto com outras experiências posteriores e o arcaico não se limitaria às experiências dos tempos primevos. O infantil representa uma experiência subjetiva ampliada, uma vez que ela comportaria uma dimensão plástica e atual. Esta visão implica em pensarmos no infantil e nos momentos precoces como sempre atuais, não designando apenas acontecimentos do passado ou surgindo somente através dos efeitos do après-coup.

Essa forma de compreender os primórdios não evoca apenas uma época específica no tempo, mas corresponde à maneira através da qual o infantil, sempre vivo e atuante em nós, vê o mundo, interpreta as experiências, sofre e tenta se proteger de novos sofrimentos. Considerar que as experiências precoces estão na base dos sofrimentos humanos e do desamparo é pensar que o infantil não pertence apenas à história passada do sujeito, mas ao presente, tendo efeitos que não se encontram presos ao tempo do passado, mas dizem respeito à história presente do sujeito (Ciccone, 2011). 
Neste sentido, em relação às experiências precoces e à clínica psicanalítica, Ciccone (2012) destaca o que ele chamou de aspectos bebê de si, que seriam estas formas de estar no mundo e de se relacionar construídas em um momento pré-verbal, mas que podem estar presentes em qualquer momento da vida do sujeito. A partir de sua experiência com observações de bebês e conjugando este braço do conhecimento com a clínica de pacientes adolescentes e adultos, o autor observou diversos traços comuns entre estes e os bebês com os quais trabalhava em suas pesquisas.

Os aspectos bebê de si estariam referidos aos traços de experiências arcaicas, guardados sob outras formas de registro sensorial, que adviriam de um momento ainda anterior à aquisição de linguagem e que se fazem presentes no e através do corpo. Através de exemplos clínicos variados, Ciccone (2011) apresenta a ideia de que todos os pacientes comportam em si estes aspectos bebê, independentemente de suas psicopatologias e que a forma de "escutar" estes elementos seria através de gestos, posturas corporais e a relação transferencial com o analista, que se modificaria quando esta forma de se relacionar mais arcaica estivesse presente na sessão.

$\mathrm{Na}$ mesma direção, René Roussillon possui algumas contribuições importantes que nos auxiliarão a pensar sobre a temática do "bebê no adulto". Em seu artigo intitulado À l'écoute du bébé dans l'adulte, Roussillon (2004a) apresenta a hipótese de que toda comunicação de um ser humano adulto, ou já dotado de palavras, deve ser considerada em diferentes níveis e modalidades de organização, especialmente um nível pré-verbal e outro pós-verbal, que convivem lado a lado durante toda a vida. Em ambos estão implícitos diferentes níveis de simbolização e inscrição psíquica, necessários para que essas formas possíveis de linguagem sejam adquiridas. Enquanto a simbolização linguageira (em ação no campo da comunicação pós-verbal) já teria sofrido um processo no qual a matéria bruta se transformou em símbolo, o primeiro tempo da simbolização diz respeito a experiências mais precoces vividas pelo sujeito e que teriam sido registradas de formas diferenciadas.

Quando a comunicação entre bebê e meio ambiente é bem sucedida, o aparelho psíquico reformula, em partes, as experiências pré ou não verbais, entrelaçando-as com uma narrativa que passa a conter palavras. Contudo, é importante marcar que as dimensões do afeto e da linguagem mimo-gesto-postural 
não desaparecem, de forma que os discursos verbal e o pré-verbal são ambos linguagens a serem utilizadas por nós ao longo de toda a vida. Assim, torna-se possível escutarmos o "bebê" presente no adulto, herança de formas de comunicação pré-verbal conquistadas a partir de experiências precoces e não integradas dos primórdios da vida (Roussillon, 2004a).

Esta dimensão arcaica vai estar presente na clínica da automutilação, trazendo à luz elementos que só podem ser audíveis a partir de uma "ampliação" da escuta do analista. Levando em consideração as contribuições teóricas descritas, podemos compreender melhor quais são as polifonias presentes de forma cada vez mais audíveis na clínica psicanalítica da atualidade. Compondo nosso campo polifônico, encontram-se o discurso verbal (com toda sua gama de associatividade) e aspectos mais estruturais do mesmo (prosódia e estrutura das frases construídas), um discurso do afeto e ainda um discurso mimo-gestopostural, levando em consideração o corpo e as posturas adotadas pelo paciente. Encontramos também o campo da sensorialidade e do ritmo, compartilhados. Todas essas possibilidades estarão presentes na comunicação entre analista e paciente, complementando as intervenções do analista, seu trabalho da interpretação de conteúdos e da associatividade verbal do par.

De acordo com Guerra (2018a), a dimensão do arcaico no sujeito adulto diz respeito a fazer contato com emoções bastante primitivas, vividas em momentos pré-verbais, que fogem ao registro das representações. Justamente por essa razão, essas emoções não estão vinculadas a palavras, se encontrando desprovidas da lógica associativa habitual que perpassa nossas relações com outros sujeitos. Não encontrando vozes que passem pela sintaxe, esses elementos podem ser fonte tanto de pavor e desamparo, quando de criatividade.

De acordo com Roussillon (2010b), os remanejamentos exigidos pelo trabalho de constituição psíquica, que passa pela integração dos fluxos sensoriais, apropriação do próprio corpo, aquisição de linguagem verbal e reorganização dos elementos pré-verbais, a partir desta nova forma de "ler" o mundo, culminando no estabelecimento de relações com outros sujeitos, são experiências que não cessam de se transformar, exigindo novas reorganizações em diversos momentos da vida. Passado e presente misturados de forma que é possível um alterar o outro. Nas palavras do autor, 
Nossa história é viva, as experiências se transformam, elas se enriquecem, isso quer dizer que, de uma certa maneira, se as experiências precoces permanecem presentes em nós, nós a atualizamos e, por isso, nós as transformamos. (p. 98, tradução nossa)

Dessa forma, podemos pensar que, na vida, assim como na clínica, haverá elementos da primeira infância do sujeito que possuem uma forma diferenciada de registro e de apresentação, condizentes com um nível pré-verbal da experiência, e que também vão estar presentes no discurso dos pacientes adultos. Ao mesmo tempo em que o analista pode ouvir elementos verbais advindos da associatividade do paciente, Roussillon (2011) aponta que ele também deve voltar sua escuta para estas outras linguagens, que escapam a essa captura do verbal.

Pensando acerca destas modalidades de comunicação, nos interrogamos sobre os diferentes níveis de escuta psicanalítica, para além do que é dito pelas palavras. Se, cada vez mais, encontramos na clínica pacientes que falam diferentes línguas, como podemos entender as condutas de automutilação? Precisamos voltar nossos olhares - ouvidos e outros sentidos - para esta singularidade polifônica que tem se feito cada vez mais presente no campo analítico atual (Cidade \& Zornig, 2019). Que outros discursos, complementares à dimensão verbal, precisariam ser acolhidos e assimilados para uma melhor compreensão sobre a temática das automutilações?

No presente trabalho, nós apostamos na compreensão dos discursos que levam em conta a sensorialidade e o ritmo; e a forma pela qual o encontro com eles nos apresentam elementos da ordem do arcaico (em suas dimensões primeva e atual). Conforme abordado anteriormente, esses discursos se constroem a partir das primeiras relações intersubjetivas de trocas entre sujeito e seus objetos primordiais. Se o psiquismo se constrói no encontro com o outro (na qualidade da presença deste encontro) através do/mediado pelo sensorial e pelo ritmo, na clínica da automutilação estes elementos também serão fundamentais na direção de (re)compor o par intersubjetivo, dessa vez formado por analista/paciente. Nessa direção, gostaríamos de apresentar alguns fragmentos clínicos que nos auxiliam a elucidar as hipóteses construídas ao longo do presente trabalho, assim como a presença destes elementos que escapam à dimensão verbal e o impacto destes na escuta e na conduta analítica. 


\section{2 \\ Fragmentos clínicos}

Para melhor compreensão do fenômeno e clarificação das discussões propostas, apresentaremos três vinhetas clínicas. Elas elucidam os diferentes tipos de automutilação que agrupamos neste trabalho, assim como apresentam seus diferentes panos de fundo, histórias e problemáticas relacionadas. A apresentação dos fragmentos tem como objetivo ampliar a discussão das hipóteses apresentadas e abrir caminho para pensarmos nas particularidades apresentadas pelos quadros de automutilação na clínica psicanalítica. As pacientes em questão foram acompanhadas pela autora e possuem seus nomes e partes de suas histórias modificadas para preservar o sigilo exigido por nossa prática profissional.

\subsection{1 \\ Hilda}

Hilda tem vinte e poucos anos, mora com seus pais e é estudante universitária. Começa a análise por exigência da família e da instituição que começou a frequentar após uma primeira internação psiquiátrica. Tem muita dificuldade em comparecer aos atendimentos, faltando bastante às sessões ou chegando bem próximo do final de seu horário. Nas sessões, parece bastante tímida, envergonhada, quase acuada. Quando comparece, fala ininterruptamente sobre tópicos variados, detalhando todo e cada assunto da semana, menos sobre suas dores e sofrimentos. Parece temerosa em confiar no espaço da terapia e me diz repetidamente sobre o medo que tem de ficar dependente das outras pessoas.

Usa sempre calças compridas e uma série de pulseiras para esconder as cicatrizes dos cortes feitos nas coxas e no antebraço esquerdo. No caso de Hilda, as automutilações costumam ser escarificações e arranhões autoprovocados. Normalmente, ela faz uso de uma faca de cozinha ou tesoura de unha, sempre isolada em seu quarto ou no banheiro da casa. De início, cortava apenas a parte interna das coxas, próximo à virilha, região em que, segundo ela, conseguia esconder bem da família e de amigos. Hilda teve raros episódios de autoqueimadura por cigarro quando não tinha acesso a objetos cortantes. Não sabe precisar o início exato dos episódios de automutilação, só diz ter sido na adolescência. 
Hilda passou pelo menos alguns anos se cortando sem que outras pessoas soubessem. Tem um relacionamento bastante complicado com a mãe, que considera extremamente ausente e intrusiva, ao mesmo tempo. Alega que a mãe não a percebe como realmente é, não se preocupando com ela no dia a dia, mas aparecendo nos momentos de maior sofrimento para, segundo Hilda, tomar atitudes extremas e contrárias à sua vontade, como foi o caso de sua primeira internação psiquiátrica. Hilda foi deixada ainda bebê na casa de uma tia distante para ser criada por ela. Passou a primeira infância afastada dos pais, que só a recuperaram quando ela já tinha em torno de quatro anos.

O primeiro a se dar conta de suas cicatrizes foi um namorado, com quem teve um relacionamento bastante conturbado. Neste cenário de brigas do casal, os momentos de angústia aumentaram e Hilda começou a cortar outros locais do corpo de forma mais impulsiva e grave. Esses episódios costumavam ocorrer após brigas e/ou tentativas de separação do namorado. Quando ele se afastava e não queria mais ver ou falar com Hilda, ela entrava em desespero e se machucava. Ela dizia que, sem ele, era como se ela própria não existisse mais, automaticamente se sentindo apagar junto com sua partida. Depois de inúmeras tentativas de alcançálo, Hilda recorria aos cortes e arranhões como forma de buscar um alívio momentâneo diante do objeto perdido, alegando não aguentar os momentos de separação, que, para ela, eram piores do que a morte.

Nas sessões, Hilda demora quase dois anos para começar a falar sobre seus episódios de automutilação. Ela relata não sentir dor no momento dos cortes e que se cortar não é uma opção consciente, mas uma imposição que vem a ela diante da perda de contato com o outro. Diz que não entende por que se machuca e que não consegue ter pensamentos enquanto está se ferindo. Não sabe o que sente ou por que sente. É só um grande vazio de angústias e o único sentimento descrito por ela é o de não existência. Enquanto o outro não pode ser acessado - não atende o celular, não abre a porta de casa - Hilda fica em um estado de "morta em vida". E, se o outro vai embora, a vida de Hilda parece ir embora com ele. É como se a existência de Hilda estivesse atrelada à existência do outro e, sem ele, ela não existisse mais. Nesse cenário, os cortes e machucados aparecem como possibilidade de barrar a ameaça de não existência, garantindo a retomada de um sentimento de estar viva e presente no mundo, garantindo seu sentimento de continuidade de existência. 
Em determinada sessão, Hilda me conta sobre uma briga que teve com o namorado e como não aguentou ao imaginar que ele iria se separar dela. Tinha um estilete na bolsa e impulsivamente o levou ao antebraço, na rua mesmo, forçando contra a pele algumas vezes até se ferir mais profundamente do que das outras vezes. Mais adiante, na mesma sessão, ela me pergunta se quero ver os cortes. Nunca tinha visto nem mesmo as cicatrizes, uma vez que ela se mantinha sempre coberta, só tendo notícias das automutilações dela através de seus relatos. Reparo que seu braço está coberto de pulseiras, impossibilitando a visão dos machucados recentes ou mesmo de um curativo.

Com a aposta de poder ouvir diferentes campos polifônicos, introduzindo na cena analítica outras ferramentas sensoriais para além do discurso verbal, respondo que sim. Ela levanta as pulseiras e chega o antebraço bem perto do meu rosto, me olhando temerosa, no aguardo de minha reação. Hilda não fala nada e ficamos um tempo compartilhando uma troca de olhares permeados por um silêncio íntimo. Olho por longos segundos, alternando o olhar entre os cortes e a expressão de seu rosto, entendendo que é a primeira vez em que ela se permite ver e ser vista, esperando uma resposta diferente do horror e da vergonha que seus cortes e queimaduras costumavam causar aos outros.

Percebo que, a partir desse momento, tivemos um ponto de virada em seu tratamento. Ela começou a confiar mais no espaço, diminuindo as faltas e os atrasos; me mostrar antigas cicatrizes e marcas deixadas em seu corpo e tentar descrever e explorar mais essas sensações advindas das automutilações, recuperando e integrando sua própria história primeva perdida em um "tempo além do tempo". Do alívio sentido através do ato de se machucar, Hilda só consegue evocar fragmentos e palavras soltas. Ela me fala das sensações que o corte evoca nela, de como percebe a textura de sua pele diferente, seu corpo mais vivo, se sente existindo no mundo naquele momento. Quando se corta e/ou queima, sabe que, naquele momento, ela é a Hilda novamente. Tem algo da sensorialidade que parece resgatar quem ela é, garantindo sua própria existência diante da ameaça de separação de um outro misturado com ela.

Hilda também começou um processo de identificar as situações de ameaça de perda do outro que a levavam a adotar essas práticas e a pensar alternativas diferenciadas, dentre elas começou a recorrer mais a mim e a pessoas de confiança quando percebia que iria começar a entrar em crise. A partir daí, pudemos costurar 
melhor acontecimentos perdidos da primeira infância, como um sentimento de abandono materno por ter sido deixada com a tia quando bebê e desencontros e desarmonias vivenciadas (em tempos passados e presentes) com a mãe que, ao mesmo tempo em que não a vê e não se interessa pelo que se passa com ela, invade na tentativa de "cuidar" dela à sua maneira, não respeitando seu ritmo de segurança.

Foi preciso que algo do meu campo sensorial entrasse em cena, o olhar e o compartilhamento afetivo deste momento da visão dos cortes, compondo um par intersubjetivo que respeitasse seu ritmo próprio e pudesse criar um ritmo compartilhado de segurança para que ela recuperasse um envelope narcísico a partir de uma nova experiência sensorial compartilhada. A importância da abertura do analista a diferentes campos polifônicos, assim como a convocação de sua sensorialidade nas sessões (em especial o olhar) também se faz presente nas vinhetas subsequentes.

\subsection{2 \\ Elena}

Elena tem em torno de quarenta anos, trabalha fora e mora com a mãe, um filho adulto jovem e o marido. Após a perda de um novo bebê, bastante desejado e esperado por ela, desenvolve uma depressão grave, com sintomas de anorexia nervosa e ideação suicida. Começo a acompanhar Elena durante sua primeira internação psiquiátrica, decorrente deste episódio depressivo. Ela está "pele e osso", com emagrecimento recente de quase 30 quilos. Apática, não reage à minha presença, não responde às minhas perguntas nem se interessa pelos acontecimentos ao seu redor, na enfermaria. De início, não fala nenhuma palavra e nem dirige o olhar a mim ou à equipe. Com o tempo, passa a se comunicar comigo fazendo sim ou não com a cabeça e, semanas depois, começa a falar, bem aos poucos.

Percebo que Elena tem os braços cobertos de pequenas feridas, como picadas de inseto inflamadas. Conforme sua angústia aumenta, o colo e pescoço começam a apresentar as mesmas feridas, por vezes o rosto também. Ela nunca fala sobre isso e, quando perguntada, diz que são os insetos do hospital. O sofrimento subjetivo parece, para ela, nada ter a ver com essas marcas físicas e 
seu discurso passa longe de qualquer relação com as feridas ou com a perda do bebê. Com o fim da internação, continuo a acompanhá-la e ela começa a falar um pouco mais de sua vida, quase nunca sobre a perda do bebê ou sobre suas feridas. Os machucados de Elena aparentemente vão sumindo junto com a melhora de sua apatia e ela volta a ganhar peso e a fazer atividades do cotidiano. Ela tem uma dificuldade enorme em comparecer aos atendimentos, assim como Hilda. Inúmeras faltas e atrasos marcam as nossas sessões, sempre com explicações objetivas e motivos externos a ela, como o trânsito, a distância, ocupações da casa etc.

Alguns meses se passam até que Elena relate um casamento anterior marcado por violência doméstica (física e verbal) e por separações e reconciliações dolorosas. Grávida do primeiro filho, Elena foi abandonada pelo marido, que sumiu sem deixar nenhuma pista de seu paradeiro. Refez-se e foi morar com a mãe, porém o marido reapareceu quase na época do parto e, entre muitas brigas, ela o aceitou de volta. Depois de sofrer um episódio grave de violência física pelo marido, decidiu se divorciar e voltou a morar com a mãe. Separar-se do marido era muito difícil para ela, que se dizia dependente dele. Se Elena costumava localizar a mãe como alguém de quem precisava estar perto para sentir-se segura e amparada, o marido alternava com ela esse lugar.

Apesar do amparo encontrado na mãe, Elena descreve momentos neste relacionamento familiar bastante conturbados, também com a mãe. De acordo com a mesma, possuía atitudes ambivalentes, ora deixando-a por conta própria em relação a tarefas infantis que ainda não estaria apta para realizar,ora querendo controlar sua vida e escolhas pessoais, como o que vestir ou comer. A mãe de Elena não concorda com suas escolhas, afetivas ou profissionais. Até hoje diz o que Elena pode ou não fazer, se deve ou não sair - e Elena acata. O marido atual tem a mesma postura, que ela caracteriza como um misto de abandono e solidão com controle absoluto de sua vida íntima. Ela se vê dividida entre as "ditaduras" da mãe e do marido.

Antes do primeiro filho, Elena teve um aborto espontâneo. Apesar da tristeza em constatar a perda do bebê, diz não ter ficado deprimida na época, por serem outras circunstâncias. Ambas as experiências de perda foram bastante violentas para ela, em termos do procedimento médico a ser realizado por conta dos óbitos fetais. Elena soube que os bebês estavam mortos e precisou se internar 
para realizar um procedimento médico de expulsão forçada do feto, espécie de "parto" de um bebê que já morreu. Algo da primeira experiência abortiva de Elena, que não tinha, até o momento, aparecido como traumática, foi resgatado e potencializado neste segundo momento. Os comportamentos automutilatórios começaram a piorar depois da perda do segundo bebê, juntamente com o quadro depressivo. Elena já estava quase na menopausa, se dando conta de que poderia ser sua última chance de engravidar e ter um filho com o segundo marido.

Apesar disso, a família não reconhece o lugar e a importância ocupada pela perda do bebê, alegando que logo ela pode tentar novamente e que tudo isso estará esquecido, não valorizando o momento de luto de Elena. Incompreendida e se sentindo só, Elena alega que os machucados a fazem se sentir viva, recuperando a garantia de estar no mundo e de se reconhecer enquanto Elena. A perda do bebê evocou nela sentimentos de ameaça de perda de si mesma.

Sem a pretensão de entrarmos em uma questão mais complexa própria ao campo de estudo do óbito fetal, que diz respeito a compreender se esta situação é uma perda narcísica ou objetal (Aguiar, 2016), pode-se entender que a situação das automutilações se repetia com Elena na direção inversa de Hilda. Enquanto para Hilda o namorado ocupava o lugar de objeto primordial, fazendo eco com o objeto que, nos primórdios da vida, não compôs um par intersubjetivo harmônico, dificultando a operação de diferenciação, e do qual ela não conseguia se separar sem se perder; em Elena foi o novo bebê que ocupou paradoxalmente este lugar. Mesmo grávida, Elena já se via compondo um par com seu bebê, oscilando momentos de indiferenciação com ele, de forma que o arcaico se torna atual em Elena através da ilusão de um corpo e uma pele compartilhadas com o bebê que estava a caminho.

Ao longo dos atendimentos, Elena nunca se queixava dos machucados no corpo. Aparentemente, eles tinham desaparecido depois do período de sua internação, mas reparo que ela estava sempre de calça comprida, de forma que eu nunca via suas pernas. Só após alguns anos de acompanhamento, Elena me relata que não tinha coragem de usar saias, pois suas pernas estavam cobertas de cicatrizes antigas e de machucados que ela continuava fazendo, alegando que não conseguia parar.

Da mesma forma abrupta que Hilda, em uma sessão posterior, Elena me pergunta se quero ver o estado de suas pernas e me mostra os machucados e 
cicatrizes levantando a barra da calça. Toda sua perna está coberta de cicatrizes, desde a coxa até quase o pé, com alguns machucados atuais. Ela diz que o movimento de se automutilar era algo que ela precisava revisitar todos os dias, "futucando" antigas feridas e fazendo novas. Quando os machucados começavam a melhorar, ela ia abrindo novamente as feridas, uma a uma, de cima para baixo, como uma onda. Não percebia o que estava fazendo e, quando via, as pernas já estavam machucadas de novo. Sentia um alívio enorme em fazê-lo, mas muita vergonha do olhar dos outros.

A partir do compartilhamento do meu olhar, Elena relata que os familiares têm horror a ver seus machucados, pedindo para que ela pare com esse comportamento. Diante da impossibilidade de parar, a família pede para que ela se cubra, de forma a não serem obrigados a ver o horror de suas dores, estampadas na pele. Novamente, como com Hilda, percebo a importância de poder vê-la, levando em conta a dimensão de sua dor - da perda do bebê, de outras continuidades e disritmias mais antigas, da dimensão de aniquilamento que a assolava quando entrava em contato com essa perda, deixando-se ir junto com seu bebê, tão investido por ela. O discurso e o desfecho da minha "intervenção sensorial" através do olhar de suas feridas autoprovocadas na análise de Elena nos levou a caminhos similares aos de Hilda. Uma confiança maior pareceu envolver nossa relação, permeada por menos faltas e atrasos, mais episódios em que ela pôde recorrer a mim para tentar falar de algo que só era vivenciado por ela no campo das sensações. Essas dimensões da sensorialidade do analista e da importância do olhar também se encontram presentes na terceira vinheta clínica.

\subsection{3}

Rita

Rita tem quase noventa anos, é aposentada e mora com a filha, o genro e dois netos. É ela quem sustenta financeiramente a casa desde que o genro começou a apresentar problemas graves de saúde e perdeu o emprego. Começo a acompanhá-la após um episódio depressivo grave com ideação suicida, a pedido dela própria. Rita sofre de uma série de doenças que foram se agravando com a idade, dentre as quais a maior fonte de sofrimento psíquico é uma degeneração macular que a faz perder a visão progressivamente. Sua maior queixa diz respeito 
a um "antes e depois" dessa mudança, pois, com a cegueira, vem também, de acordo com ela, maior dependência dos outros.

Em relação às sessões, tivemos um início de adaptação bastante complicado. Rita não aceitava muito bem a minha presença (apesar de ter sido ela a fazer um pedido de análise). Dizia que eu não iria conseguir ajudá-la e, apesar disso, tinha medo de ficar dependente de mim. Passava muito tempo da sessão contando coisas triviais do cotidiano e alegando estar entediada, pois não sabia como eu poderia deixá-la melhor. Desmarcava muitas vezes e me mantinha emocionalmente longe, parecendo não confiar. Precisava que eu entrasse em seu ritmo, sempre exigindo que eu a visse nos dias e horários convenientes para ela. Nunca fazia concessões e ficava extremamente frustrada quando não nos víamos em feriados ou nas minhas férias.

Inicialmente, Rita chorava bastante nos atendimentos e falava de um desejo muito forte de desaparecer. Que preferia estar morta para não depender de mais ninguém, como pensava constantemente em se jogar pela janela do quarto. A única razão que a mantinha viva era a religião. Rita tinha uma cruz com um terço e várias imagens de santos entre sua poltrona e a janela, espécie de escudo protetor. A família relata episódios de automutilação nos dedos das mãos, que ficam bastante machucados em torno das unhas, arrancando a pele dos dedos com as unhas até ficarem em carne viva e precisarem de intervenções médicas.

Após mais de um ano, ela me fala sobre as automutilações e conta que sempre fez uso dessa prática, desde adolescente, mas não lembra como ou por que teria começado a se machucar. Percebe uma piora quando está passando por um momento difícil na vida, repleto de angústias insuportáveis e diz que não consegue controlar o impulso de se machucar. Por vezes, Rita também arranca os pelos da sobrancelha até formarem buracos em seu rosto. Essa prática, segundo ela, é nova, tendo aparecido apenas nos últimos dois anos, neste último episódio depressivo.

Rita relata ter tido uma vida difícil, tendo sobrevivido a um casamento repleto de abusos (físicos e verbais). O marido a xingava e humilhava desde o início do casamento, comportamento este que foi evoluindo ao longo do tempo para episódios de violência física bastante graves. Por vergonha da família, nunca compartilhou com eles sua história. Também nunca teve coragem de deixar o marido, apesar de ser ela quem sustentava a casa financeiramente desde o início 
do relacionamento. Rita escondia as marcas das agressões e a sua única confidente era uma prima, a quem é bastante ligada até hoje. Uma das queixas atuais de Rita é que esta prima está com um princípio de Alzheimer, não conseguindo mais dar a ela o suporte de antes.

Rita teve um relacionamento conturbado com a mãe, que dizia ser uma pessoa bastante comprometida. A mãe tinha um problema grave de saúde e usava isso como chantagem para controlar a vida das filhas. Assim como Hilda e Elena, Rita descreve uma mãe ao mesmo tempo distante e intrusiva. Ela diz que vivia apanhando sem motivo, apenas por "traquinagens" de criança. A mãe a obrigava a trazer uma vara de bambu e dizia que se Rita não aceitasse apanhar, ela morreria decorrente de sua saúde frágil. Rita diz que apanhava para a mãe não morrer.

Rita conta que sempre precisou de uma outra pessoa para gerir sua vida, se sentindo uma pessoa bastante dependente, desde a infância. Tem uma irmã poucos anos mais velha e diz que, antes, era a irmã quem cuidava dela. A irmã a ajudava na escola, a protegia das brigas com a mãe, comprava comidas e roupas para ela. Com o tempo, esse lugar de dependência foi substituído por essa prima, que a acolhia em tudo e sabia mais da sua vida do que a própria Rita. Ela diz que a prima era sua memória, de forma que até quando iam ao médico era a prima quem relatava os problemas de Rita. Com o princípio de Alzheimer da prima, vieram outros problemas de saúde, que criaram um alerta em Rita da possível perda da mesma. Rita fica apavorada com a ideia de perdê-la, como se sua existência estivesse vinculada à dela.

Assim como nos relatos de Hilda e Elena, em uma sessão, Rita começa dizendo que precisou ir ao médico para cuidar dos ferimentos das unhas, que infeccionaram. Apesar de não esconder as mãos ao longo das sessões, como as outras pacientes escondiam seus ferimentos, Rita as posiciona perto do meu rosto, os direcionando a mim pela primeira vez. Ela pergunta se estou vendo o quanto ela sofre, se a partir desta visão de suas peles arrancadas eu consigo compreendêla, alegando que a família não a vê como realmente é. Diz que eles não a conhecem e nem têm interesse em conhecê-la, com exceção da prima. A partir daí, consegue iniciar um processo de tentar descrever o universo de sensações de aniquilamento que a assolam a partir das ameaças de separação das figuras importantes para ela. 
Seus episódios automutilatórios atuais costumam estar relacionados à piora no estado de saúde da prima (físico ou mental) ou a alguma separação real entre ambas (viagens, internações hospitalares etc.). Outras situações de separação de sua cuidadora, por conta de férias, ou da irmã, quando passam algumas semanas juntas, também parecem ultrapassar esse limiar do suportável. Apesar de se descrever como uma pessoa que depende dos outros, como se isso não causasse sofrimento psíquico, quando estas pessoas faltam ou não podem estar lá para ela, é como se entrasse em um colapso do corpo. Começa a ter outros sintomas corporais bastante primitivos, tais como piora da visão, um sentimento de vazio na cabeça, que, segundo ela, começa a crescer, e um inchaço no estômago. Rita tem sentimentos de que vai explodir ou desaparecer quando começa a sentir essa angústia excessiva e a única forma que possui para diminuir esse vazio é se machucando.

A partir dos três fragmentos de casos clínicos apresentados, podemos perceber alguns pontos em comum entre as pacientes e suas dinâmicas na clínica. Hilda, Elena e Rita apresentam práticas bastante diferentes de automutilação. No entanto, todas utilizam esse recurso de ferir a própria pele para escapar de sentimentos de extrema angústia e vazio, recorrendo ao corpo para sentirem que existem e que são contínuas no tempo e no espaço. As três também possuem um início de vida conturbado com a mãe e com o ambiente, de forma que situações de intrusão e violência, mescladas com uma ausência afetiva e falta de sintonia com o outro, já parecem marcar suas histórias.

Outra coincidência são as histórias de violências físicas e domésticas narradas pelas três. Relacionamentos amorosos conturbados que, por mais que as fizessem mal, não conseguiam deixá-los. Em relação à dimensão da violência, observamos que ela parece aparecer desde os primórdios da vida, na forma de dificuldades na sintonia mãe-bebê. Os ritmos que constituem o sentimento de ser e a garantia da continuidade de ser no espaço parecem atropelados pela dificuldade relacional no início da vida, de forma que estas pacientes, assim como os bebês pequenos, precisam da presença física do outro para sentir que existem. 
Estes fragmentos nos auxiliam a nortear algumas discussões propostas ao longo do presente trabalho. Em primeiro lugar, encontramos nas vinhetas a ilustração das hipóteses de que a continuidade de existência do sujeito se encontra prejudicada nos casos de automutilação e de que a ameaça de integridade narcísica está diretamente relacionada com situações de separação (sejam ameaças ou a situação propriamente dita). Retomando as contribuições anteriores, podemos pensar que situações desarmônicas e marcadas por disritmias no par mãe-bebê se passaram nos primórdios do par intersubjetivo inicial, de forma que as descontinuidades frequentes e/ou precoces ocorreram em momentos nos quais o bebê ainda não conseguia se ver como totalmente diferenciado da mãe, levando à ilusão da perda de si mesmo através da perda do outro.

Nas três vinhetas clínicas expostas há situações de confronto com separações da vida adulta que nos remetem a esse início das operações de diferenciação eu/não-eu. Com o afastamento ou com a perda de "substitutos" do objeto primordial, o sujeito se sente ameaçado narcisicamente, de forma que recorre ao sensorial como possibilidade de integração momentânea, tendo sua existência garantida através das feridas autoprovocadas. O sentimento de nãoexistência encontra-se fortemente presente nas três pacientes, assim como o alívio garantido pelo ato automutilatório.

Outro elemento importante a ser destacado é o lugar que ocupam as trocas sensoriais na clínica da automutilação, especialmente em relação ao olhar do analista. Estar aberto para outros elementos que complementam a associatividade verbal e a interpretação aparece nesta clínica como ferramenta essencial de trabalho analítico, abrindo o campo polifônico para a escuta de elementos da ordem do arcaico, advindos das primeiras relações intersubjetivas.

Essa escuta será fundamental no estabelecimento de uma zona de compartilhamento afetivo e sensorial daquilo que se passa com o paciente em seu próprio corpo, conjugando passado e presente, psíquico e somático. Ocupando um lugar de presença objetal diferenciado, estando presente de corpo inteiro, não apenas com ouvidos para as palavras, mas colocando em jogo outras escutas, o analista poderá compor um par intersubjetivo com o paciente, inicialmente se adaptando ao ritmo de segurança do paciente na direção de uma coconstrução rítmica própria ao par analista/paciente. 


\section{3 \\ A dinâmica do "mostrado/escondido" e a importância do olhar como possibilidade de integração}

A visão do ferimento, a marca entalhada por ele, assim como a possibilidade de escondê-lo dos outros são características fundamentais no ato da automutilação. Agredir a si mesmo é um ato que deixa rastros, prolongando sua dimensão para o futuro. Por outro lado, a incidência dos locais feridos nos fala sobre uma marca que pode ser ocultada, selecionando assim quem será espectador deste acontecimento. A dinâmica do "mostrado/escondido" presente nestes quadros é destacada por diferentes autores e diz respeito justamente à possibilidade de um ato que pode escolher quem, quando e como olhar para suas feridas (Corcos \& Richard, 2006; Pommerau, 2006b; Dargent, 2010).

Conforme apresentado anteriormente, as lesões costumam ser realizadas em locais de fácil ocultação. É bastante comum encontrarmos como recurso o uso de roupas de mangas compridas ou calças, assim como um vasto número de pulseiras e adereços no braço com o intuito de esconder as lacerações e/ou cicatrizes deixadas, como no caso de Hilda e Elena. Os sujeitos se ferem na privacidade de suas casas e quartos fechados, de forma que outros não necessariamente encontram pistas de seus atos. Por outro lado, é um agir que deixa uma marca na pele, podendo ser avistada, caso esta esteja descoberta. $\mathrm{Na}$ dinâmica do mostrado/escondido, o sujeito pode selecionar para quem ele quer mostrar seus ferimentos e de quem ele quer esconder.

Nesta direção, gostaríamos de propor uma correlação entre o par mostrado/escondido e a importância que parece ser atribuída ao olhar do analista. Conforme as vinhetas clínicas apresentadas, o convite feito ao analista para que veja as feridas autoprovocadas das pacientes, convocando outros sentidos para além da escuta verbal, parece ter um papel preponderante como contenção temporária diante da ameaça de desintegração.

Como base para a discussão proposta, evocamos a teoria winnicottiana, que atribui uma importância ímpar ao olhar materno como fator constitutivo e crucial nos processos de maturação egoica, em que "ser visto" é uma experiência fundamental para a constituição narcísica do sujeito e do sentimento de continuidade de existência, assim como do "sentir-se real". De acordo com o autor, este sentimento é maior do que apenas existir, seria "descobrir um modo de 
existir como si mesmo, relacionar-se aos objetos como si mesmo e ter um eu (self) para o qual retirar-se para relaxamento" (Winnicott, 1967/1975c, p. 161).

Em seu artigo $O$ papel de espelho da mãe e da família no desenvolvimento infantil, Winnicott (1967/1975c) desenvolve a ideia do rosto materno funcionando como um espelho que refletiria o próprio bebê. Partindo de sua premissa inicial de que o ambiente possui papel vital no desenvolvimento emocional, o autor sublinha que o bebê costuma ver ele próprio refletido quando observa o rosto da mãe. $\mathrm{O}$ bebê olha para a mãe e ela devolve para ele a visão que possui do bebê, de como ele se constitui enquanto sujeito, suas características, sentimentos e processos internos. $\mathrm{O}$ bebê depende desse olhar para se constituir narcisicamente.

Baseando-se neste artigo, Roussillon (2015) aponta a função de espelho do rosto da mãe como uma das mais importantes experiências de constituição narcísica. É a partir de sua visão refletida naquele rosto que a criança se descobre e inicia o processo de realizar suas identificações. Quando esta função é insuficiente ou falha, o ambiente interpreta os estados afetivos do bebê de acordo com seus próprios estados internos, atropelando um processo de descoberta rico e criativo, lançando o bebê no desamparo das descontinuidades e das falhas narcísicas. Como consequência, o bebê vive uma decepção narcísica primária, que suporta sem poder identificar exatamente a fonte de seu mal-estar.

Ao longo de seu desenvolvimento, o bebê vai encontrando outros olhares que podem auxiliar em sua constituição e integração em diferentes momentos da vida. No trabalho citado anteriormente, Winnicott (1967/1975c) faz um paralelo entre o olhar constitutivo da mãe e a experiência da psicoterapia. Para ele, a psicoterapia tem relação com o espelhamento do olhar do analista - para além das interpretações. Nas palavras do autor: “[A psicoterapia] É um derivado complexo do rosto que reflete o que há para ser visto" (p. 161), ou seja, a análise consiste em podermos acompanhar, observar e refletir para o paciente seu funcionamento, elementos que ele mesmo tenha trazido para aquele espaço.

Ampliando o sentido dado por Winnicott para o olhar da mãe/analista, nos indagamos acerca da importância que o olhar do analista adquire na dimensão arcaica dos casos de automutilação. Momentaneamente, o sujeito que se mostra e é visto por um outro pode se sentir observado neste aspecto particular, ter acesso ao seu reflexo através do olhar alheio, e se sentir real. 
Sobre a importância do olhar do outro como possibilidade de integração narcísica, destacamos ainda os trabalhos de Haag (2018) sobre a interpenetrabilidade do olhar presente no par mãe-bebê nos primórdios da vida. Complementando os trabalhos de Tustin, Haag (2004) destaca que a importância das trocas emocionais iniciais ocorridas entre o par só podem ocorrer através dos suportes sensoriais e rítmicos. A autora apresenta sua hipótese de que estas trocas fundamentam no bebê, a princípio, uma percepção de superfície, organizando para o bebê um mundo inicialmente em duas dimensões (2D), e construindo aos poucos um "fundo" que possibilitaria acessar o mundo em três dimensões (3D).

O primeiro momento destacado tem relação com as discussões apresentadas acerca do conceito de eu-pele (Anzieu, 1985/2000) e da bidimensionalidade provisória a partir da ilusão de "peles compartilhadas". Para explicitar este momento, Haag (1986) apresenta o conceito de identidade adesiva, alegando que este termo é de autoria de Esther Bick. O termo designa uma modalidade de existência bastante primitiva, segundo a qual a forma de adquir identidade seria através de uma espécie de "cola" com o outro primordial. A autora dá como exemplo do mundo animal as sanguessugas, que, para sobreviver, precisam estar coladas a outros animais.

Apesar da própria Bick e de autores como Meltzer se referirem à adesividade em seu viés patológico, Haag (2004) ressalta seu caráter constitutivo, afirmando que a identidade adesiva seria um estado normal do desenvolvimento do bebê. Ela surge como nível identificatório anterior à identificação por projeção, que já teria um mínimo de sentimento de separação corporal entre mãe e bebê. No estado adesivo, preserva-se a ilusão de "um corpo para dois" (McDougall, 1987) e da fantasia das peles compartilhadas (Anzieu, 1985/2000), se configurando como um período marcado pela ilusão de maior indiferenciação com a mãe. Neste sentindo, a adesividade é bidimensional, concebendo o mundo 2D, que mantém colado ilusoriamente o par mãe-bebê.

$\mathrm{Na}$ direção da adesividade como fase constitutiva do psiquismo, Haag (1986) sublinha ainda que Bick propunha a ideia de posição adesiva, pensando nas contribuições de Melanie Klein acerca das "posições" esquizoparanoide e depressiva, de forma que estes modos de estar no mundo não se perderiam ao longo do tempo, apenas se complementariam com as outras posições propostas. 
Para que o bebê passe do momento bidimensional adesivo para adquirir a noção de fundo e de continência, a troca de olhares entre a mãe e o bebê será fundamental para Haag (2018). É a partir do jogo de olhar combinado entre mãe e bebê que a superfície pode se esfericizar, tornando-se um volume, envelope que pode passar a conter conteúdos. Esta formação tridimensional do sujeito passa pela integração da pele, que vai de superfície de contato (contando com apenas dois lados, como uma folha plana de papel), à vesícula continente (como uma esfera). Só a partir desse movimento de transformação na percepção do entorno é que o mundo do bebê começa a se constituir em 3D, podendo haver o início de uma percepção de si mesmo e do outro como entidades diferenciadas.

De acordo com Haag (2004), nesta passagem rumo à tridimensionalidade, há um movimento de interpenetração de olhares, no qual, a partir da troca sensorial e rítmica entre mãe e bebê, o olhar do bebê busca o olhar da mãe e encontra nele um fundo, indo além da camada bidimensional anterior. Quando o olhar do bebê atinge esse fundo, ele é devolvido pelo olhar da mãe, similar às contribuições winnicottianas sobre o rosto da mãe como refletindo o próprio bebê. Haveria um "efeito rebote", que devolveria para o bebê algo diferente de si mesmo, consolidando o envelope que o constitui. Esse efeito rebote precisa ser reflexivo, produzir um espelhamento.

Haag (2018) considera que, através desta troca de olhares nutrida por uma relação rítmica e sensorial harmônica no início da vida, o bebê vai experimentando estados de integração cada vez maiores, em direção à diferenciação. A partir daí, o bebê vai conquistando uma imagem esfericizada de si, mais próxima da integração e da diferenciação de si mesmo do que da colagem indiferenciada bidimensional com a mãe. É importante destacar que este encontro de olhares precisa passar pelo que Haag (1990) chamou de encontro elacional, que seria o resultado de muitos encontros harmônicos e frutos de uma sintonia inicial entre mãe e bebê.

De acordo com a autora, é esse caráter de "bons" encontros intersubjetivos o que possibilitaria que o bebê fosse refletido no olhar da mãe, levando a uma espécie de "duplicação" de si mesmo para poder se sentir separado do outro primordial, sem sentir as descontinuidades do outro como um "arrancamento" de partes de seu próprio eu ou como um sentimento de desintegração e aniquilamento. 
Dessa forma, entendemos que a continência começa com o olhar, só sendo possível que a pele cumpra seu papel de integração física do eu a partir de uma relação intensa de troca de olhares. De acordo com Haag (1990), o que leva os pacientes a se sentirem novamente integrados muitas vezes não são elementos da ordem do verbal, mas o reencontro de "uma intensa comunicação olhar-psique com uma circulação emocional" (p. 114). Ainda em relação aos pacientes, a autora afirma que

quando se compreende, quando se toca no ponto exato, o olhar pode novamente penetrar: é feito de penetração e de suavidade e encontra um fundo, consolidando o envelope, produzindo algo que realmente consolida o eu. (p. 108)

Complementando as contribuições, podemos pensar com Konicheckis (2016) que o encontro com elementos advindos do campo da sensorialidade na clínica pode favorecer novas simbolizações, dando novos sentidos ao que está sendo sentido. De acordo com o autor, as sensações não só fazem parte da constituição do eu, como também podem favorecer futuros processos de subjetivação e de experiências psíquicas inéditas ao longo da vida do sujeito.

Segundo Konicheckis (2008; 2018), as experiências iniciais compartilhadas com os objetos, que só podem ser sentidos através da sensorialidade, gerariam o que ele chamou de embriões de sentido: espécie de germe de infinitas possibilidades futuras a partir destes elementos primevos. De acordo com a qualidade dos encontros iniciais com o objeto, estes embriões ficariam guardados em um passado que se atualiza a partir de novas experiências e novos encontros, possibilitando uma experiência futura de crescimento pessoal e/ou de sofrimento psíquico. Segundo o autor, esses embriões de sentido funcionam como matrizes geradoras de novas criações, dando a chance de novas experiências constitutivas a partir de novos encontros sensoriais e intersubjetivos.

Pensando acerca dos casos de automutilação, podemos ressaltar algumas repercussões que esta problemática apresenta para a clínica psicanalítica. A partir do recurso ao sensorial, no extremo de ferir a própria pele, estes sujeitos podem recuperar algo de sua integridade narcísica a partir do próprio plano do sensorial. Partindo da importância de acolhermos na clínica da automutilação elementos complementares ao campo do verbal e da associatividade, nos voltamos para a possibilidade de "ouvir" elementos advindos do sensorial, especialmente o olhar do analista. Estas possibilidades polifônicas auxiliam a compor novos encontros 
intersubjetivos com estes pacientes, na esperança de serem encontros mais harmônicos e em direção a uma sintonia mais afinada para ambos. 


\section{5 \\ Considerações finais}

Para entender nós temos dois caminhos: o da sensibilidade que é o entendimento do corpo; e o da inteligência que é o entendimento do espírito. Eu escrevo com o corpo. Poesia não é para compreender, mas para incorporar. Entender é parede; procure ser árvore.

Manoel de Barros

A finalidade do presente trabalho foi a de refletir acerca da dimensão arcaica das automutilações. Se, por um lado, a automutilação comporta uma dimensão edípica, contendo relação direta com a problemática da adolescência e seus remanejamentos e revivescências, nos aprofundamos sobre sua dimensão arcaica, que diz respeito a problemáticas mais narcísicas do início da vida, de construção do eu-corporal, da dimensão do sensorial e dos processos de diferenciação. A dimensão arcaica proposta na tese tem como referência elementos dos primórdios sensoriais que não se encontram perdidos em uma memória "passada" dos acontecimentos cronológicos, mas sim ativos no presente e no atual, nas formas de se relacionar com os outros sujeitos.

Com o intuito de percorrer a discussão proposta, iniciamos nosso percurso teórico recuperando os principais trabalhos acerca da temática da automutilação. No primeiro capítulo, abordamos a complexidade dos estudos sobre o tema, partindo das diferentes definições existentes na literatura sobre o fenômeno, inicialmente circunscritas ao campo da Psiquiatria e posteriormente apropriadas pela Psicanálise, e suas interlocuções com temas correlatos.

Destacamos que a automutilação não se limita aos cortes superficiais na pele, como ela é frequentemente representada, mas diz respeito a uma série de condutas diferenciadas que tem em comum os danos infligidos à própria pele. Estas condutas podem ser encontradas, em sua maioria, contendo uma relação com quadros psicopatológicos mais graves, como o autismo e a psicose, ou com o momento de transições e mudanças advindas da adolescência, ressaltando um caráter transnosográfico presente nas automutilações.

Sublinhamos ainda $o$ fato de que a automutilação não possui homogeneidade como conceito, nem em relação à nomenclatura, nem no que se 
refere à compreensão do fenômeno, apesar de destacarmos, enquanto definição de automutilação adotada por nós, a dimensão de ataque à própria pele. Este ato provoca uma laceração, assim como uma ruptura e descontinuidade do tecido epitelial, o que caracteriza o fenômeno que estamos optando por manter com a nomenclatura de automutilação. Ressaltamos que o presente trabalho se apoia em uma escuta clínica que comporta diferentes casos e situações subjetivas, conjugando tipos diversos de automutilações.

Sobre o universo amplo das automutilações, destacamos os trabalhos de Karl Menninger e Armando Favazza. Menninger (1938/1970) propõe compreendermos a automutilação como o equivalente a direcionar um impulso suicida para uma parte específica do corpo, ao invés de deixá-lo atingir a totalidade deste. Armando Favazza (1987/2011) desenvolveu uma classificação das automutilações, dentro do terreno da Psiquiatria, que é a mais conhecida e utilizada nas pesquisas contemporâneas, tendo se tornado referência nos estudos sobre a temática referida. $\mathrm{O}$ autor reagrupa as automutilações em três grandes categorias fenomenológicas: 1) Automutilação maior; 2) Automutilação estereotipada; 3) Automutilação superficial/moderada. No recorte teórico da presente pesquisa, optamos por utilizar apenas as automutilações pertencentes a este terceiro grupo, visando a uma melhor compreensão das discussões propostas.

Abordamos ainda a questão do estatuto do fenômeno da automutilação. Tratar-se-ia apenas de um sintoma, prevalente em diferentes quadros clínicos, ou estaríamos falando de uma síndrome, entidade clínica diferenciada que afunila e congrega outros comportamentos? De maneira geral, compreendemos que o fenômeno das automutilações existe de forma recorrente na clínica em suas duas formas: fragmentada, corroborando a ideia de um fenômeno transnosográfico e plural; assim como autônoma, com características próprias que convergem para uma compreensão mais sindrômica deste comportamento. Uma forma de aparecimento não invalida e nem enfraquece a outra. Ambas são possíveis e podem ser compreendidas dentro de suas limitações teóricas.

Outra questão importante, própria ao terreno das automutilações, que foi abordada neste trabalho, diz respeito à tentativa de diferenciar a automutilação de um comportamento suicidário. Alguns autores acreditam que as diferenças existentes entre a automutilação e a tentativa de suicídio são de ordem quantitativa, descrevendo um contínuo de autodestruição que vai da 
automutilação ao suicídio propriamente dito, tais como Ross e McKay (1979) e Pattison e Kahan (1983). A maioria dos autores acredita se tratar de problemáticas distintas, marcadas por uma diferença de ordem qualitativa, e aponta a automutilação como uma espécie de barreira protetora contra o suicídio, último recurso radical contra o ataque total ao corpo (Menninger, 1938/1970; Favazza 1987/2011; Muehlenkamp, 2005; Gicquel e Corcos, 2011).

Em consonância com Dargent e Matha (2011), acreditamos se tratar de um fenômeno que comporta, ao mesmo tempo, duas dimensões aparentemente contrárias: se, por um lado, podemos entendê-lo como efeito e destino de uma destrutividade que se volta para o próprio corpo, por outro lado, podemos também compreendê-lo como um ato a serviço da vida, uma vez que preserva a existência do sujeito. Apostamos na ideia de que os fenômenos automutilatórios, apesar de causarem dor e sofrimento, também constituem o sujeito, em sua maneira mais primitiva de ser. Estas "autoferidas" sustentam algo de suas vivências precoces, auxiliando-os a manterem-se vivos, a sentirem que existem e são contínuos ao longo do tempo e do espaço. Esta aposta esteve na base da construção do presente trabalho como um todo, entremeando o diálogo entre os fenômenos de automutilação e o estudo da constituição psíquica.

No segundo capítulo, apresentamos diversos autores que trabalham o tema das automutilações em Psicanálise e que vão atentar para a dimensão privilegiada que ganha o corpo nesses fenômenos. É o corpo que manifesta um sofrimento que não pode ser colocado em palavras e através do qual o sujeito encontra uma via de expressão e de descarga daquilo que o faz sofrer. No cenário das autoferidas, é o corpo que está à frente. Ele denuncia conteúdos e vivências que ultrapassam o universo das representações psíquicas e que apontam para outras formas de aparição dessas excitações que não estão contidas de forma representacional. A convocação ao corpo aponta para o irrepresentável de um excesso pulsional que não pôde ser contido e que ultrapassou os limites psíquicos daquele sujeito.

A importância atribuída ao corpo como local privilegiado de sofrimento traz um ponto de contato importante na Psicanálise entre os fenômenos automutilatórios e o período da adolescência, momento de prevalência de aparição destas práticas. Abordamos a relação existente entre as automutilações na adolescência e as diversas ressignificações próprias a este momento da vida, na qual o corpo púbere e as novas correntes pulsionais vêm à tona e exigem um 
árduo trabalho de mudanças. Dificuldades em lidar com os remanejamentos próprios da adolescência (corporais, psíquicos e sociais) podem se configurar como uma ameaça de perda da integridade narcísica mediante tantas transformações no processo de construção identitária. Diante desse cenário, encontramos a automutilação como uma saída radical de recurso ao corpo diante de um psiquismo que não dá conta do excesso pulsional que o invade, na tentativa de conter e de dar destinos a essa carga.

Apesar da alta prevalência dos comportamentos automutilatórios neste momento específico da vida, o foco do presente trabalho não se restringiu às problemáticas referentes à automutilação na adolescência. Contudo, há um interesse nos entrelaçamentos possíveis entre as duas temáticas: tanto na prática da automutilação quanto na adolescência encontramos o recurso ao corpo e ao sensorial como tentativa de contenção do eu em momentos nos quais o sujeito sente que pode haver o risco da perda da integridade narcísica. Nossa hipótese, desenvolvida ao longo da tese, foi a de que essas separações, que levam ao recurso radical de ferir o próprio corpo, seriam vivenciadas de forma que sujeito e objeto não se encontram ainda devidamente diferenciados, seja na adolescência, seja na vida adulta.

Se, na adolescência, encontramos uma exigência de trabalho psíquico com o intuito de ressignificar o corpo e o sexual que surgem com uma novidade, ressaltamos que o período da adolescência traz consigo a ressignificação de processos primários e secundários. $\mathrm{O}$ universo das vivências anteriores à aquisição de linguagem verbal compartilhado entre o par mãe-bebê encontra-se em foco quando o corpo está à frente da cena, mais ainda se falamos sobre práticas que envolvem a pele.

Sublinhamos que o arcaico se mantém e se presentifica em diferentes momentos de nossa existência, incluindo no presente trabalho uma reflexão acerca da temporalidade. Em consonância com Gicquel e Corcos (2011), propomos a ideia de que as automutilações encontradas na adolescência falam de um sofrimento psíquico que é anterior a esse momento, mas que está sendo ressignificado junto com o trabalho da adolescência. Afirmamos, com Golse e Roussillon (2010), que fenômenos clínicos que passam pelo corpo ou pelo ato são testemunhas de um arcaico ainda vivo e sempre atuante na vida psíquica dos sujeitos. 
$\mathrm{Na}$ tentativa de compreender o fenômeno das automutilações, nos voltamos para dois eixos principais que compõem essa problemática: o eixo somato-psíquico e o eixo narcísico-objetal. Em relação ao primeiro eixo, observamos que, nas automutilações, há maior dificuldade na elaboração psíquica dos sofrimentos vivenciados pelo sujeito, de forma que o corpo passa a ser lugar privilegiado de reconhecimento desses sofrimentos; já em relação ao eixo narcísico-objetal, entendemos que o excesso pulsional dá origem a um recolhimento narcísico na tentativa de preservar o eu ameaçado. Estes dois eixos encontram-se entrelaçados, de forma que só é possível construir uma boa costura entre corpo e psiquismo a partir do momento em que se fundam bases narcísicas consistentes, formadas a partir dos primeiros encontros com o objeto.

Nesse sentido, propusemos voltar nossas atenções para a dimensão préverbal no universo das automutilações. Se esse fenômeno se ancora no corpo, tudo que se passa nessa seara ganha um peso diferenciado. Sabemos que, antes de sermos capazes de nos representarmos psiquicamente, o eu existe no e através do corpo. O corpo vem antes da palavra, das representações e dos pensamentos. Começamos a existir pelo corpo e a dimensão corporal nos constitui e acompanha ao longo de toda a vida.

Ampliando a dimensão do corpo nas automutilações, nos propomos a pensar acerca da especificidade deste ato: a dimensão de ataque à própria pele como condição de possibilidade para o ato em si. Se nas condutas automutilatórias encontramos um ego fragilizado e ameaçado pelo risco da perda da integridade narcísica, apostamos que, neste momento bastante inicial da vida, no qual os acontecimentos são registrados no corpo, estes sujeitos teriam vivido uma série de experiências para as quais o ego ainda não estava preparado psiquicamente para elaborá-las, deixando como rastro uma série de falhas na constituição psíquica.

Sustentamos, com Roussillon (2007), que a problemática central da pele é a da diferenciação eu/não-eu, uma vez que a função principal do eu-pele seria realizar um primeiro esboço de delimitação entre o eu e o ambiente. Contudo, este processo de diferenciação que culminará no limite entre sujeitos só pode se efetuar se um primeiro tempo tiver se passado de forma satisfatória: o da construção da fantasia de uma pele comum entre mãe e bebê (Anzieu, 1985/2000) e da ilusão de um corpo para dois (McDougall, 1987). As nuances deste momento 
compartilhado pelo par vão constituir as particularidades do processo de diferenciação, podendo culminar em falhas prematuras no processo.

No caso das automutilações, sujeito e objeto não se encontram devidamente diferenciados, de forma que há uma confusão entre ambos os corpos e os limites do sujeito encontram-se falhos, denunciados pela problemática trazida à tona pelo ataque à própria pele. Se a qualidade de presença do outro não foi suficiente, gerando problemas nos vínculos e relações com os objetos, a capacidade do sujeito de habitar a própria pele e de se sentir integrado e coeso pode ficar prejudicada. Nesse caso, os objetos podem vir a ser sentidos como ameaçadores, uma vez que os limites entre sujeito e objeto não estão estabelecidos de forma segura ou garantidos no tempo e espaço. Se a pele é o órgão que delimita fisicamente onde termina o sujeito e começa o objeto, o ataque à pele nos dá notícias deste limite falho e uma "confusão de peles" e de corpos que permanece ao longo da história do sujeito.

No terceiro capítulo, voltamos nossas atenções para explorar este início intersubjetivo no qual começavam a se delinear sujeito e objeto como entidades separadas, nos debruçando sobre o processo de diferenciação que garante a ilusão de integridade narcísica. Apontamos que a questão da separação é primordial nos casos de automutilação. Observamos que as crises (e recaídas) costumam ser desencadeadas em um contexto de perda e/ou de separação de algum familiar, de um cônjuge ou pessoa a qual o paciente atribui uma importância ímpar, ou ainda na iminência dessa separação/perda.

Encontramos em Quinodoz (1991/2014) duas operações possíveis que levam em conta a seara das separações: a separação propriamente dita, que pressupõe uma relação anterior entre dois sujeitos diferentes, contemplando a noção de que cada um é uno e discriminado perante o outro; e a diferenciação, quando a separação é vivida antes que surjam em cena dois sujeitos distintos, ou seja, sujeito e objeto ainda estão entrelaçados e confundidos.

Com base nestas contribuições, propusemos a hipótese de que os fenômenos de automutilação constituem uma defesa frente à ameaça de perda do outro, que é sentida como ameaça de perda de seu próprio eu. Teria havido uma precocidade nas vivências de separação e ausência do objeto primordial, sem que os processos de diferenciação já estivessem operando no bebê, não respeitando seu tempo de constituição necessário. Nestes casos, a ausência precoce ou 
repentina do outro traz a percepção dolorosa de sua presença como não-eu e estamos diante de um problema diferente, uma vez que a integridade narcísica do sujeito não está garantida.

Afirmamos que, no início da vida, a questão da diferenciação se coloca atrelada ao terreno da intersubjetividade: para que o bebê se veja separado da mãe, será necessário passar por uma experiência de estar submetido ao mundo para começar, gradativamente, a ter consciência de que ele existe e de que está vivo, até chegar em um sentimento de ser uno e separado da mãe. Ressaltamos que o nascimento do psiquismo encontra-se indissociável do nascimento do objeto (Golse \& Roussillon, 2010). No começo, o contato entre o bebê e o mundo ocorre através da sensorialidade e do ritmo, continuidades e descontinuidades que marcam suas experiências.

Com base nas contribuições de Prat (2007), sublinhamos que, no começo da vida, as primeiras experiências sensíveis são inscritas na dualidade da alternância entre estar em contato e estar sem contato, desde o útero materno. Essa hipótese traz à tona a dimensão do ritmo, indissociavelmente ligada à dimensão da pele e do toque, pois é através das continuidades e descontinuidades do toque (seja no ventre materno com as paredes uterinas, seja do bebê pósnascimento) que alguma dimensão do "não-eu" pode começar a ser esboçada no bebê.

Nos primórdios da vida, afirmamos com Tustin (1984) que ainda não há a concepção de um objeto distinto, separado do bebê. Encontramos uma vivência de ilusão de que ele e a mãe são partes do mesmo corpo, e as partes do corpo da mãe com as quais se tem contato são sentidas pelo bebê como sendo partes de seu próprio corpo, preservando o bebê do contato precoce com os objetos. Se vivências de separação ou descontinuidade excessiva com o objeto primordial são recorrentes, transbordando as capacidades de paraexcitação do par mãe-bebê, os processos que se instauram no bebê não são da ordem da separação entre sujeito e objeto, mas evocam uma sensação de aniquilamento que transborda o bebê. Se o outro primordial é sentido como parte dele próprio, as vivências de descontinuidade deflagradas pelo desaparecimento do outro têm proporções catastróficas de perda de si mesmo no bebê.

Estas situações constituem o que Golse (2014) chamou de violências da diferenciação, para se referir a episódios nos quais as vivências de diferenciação 
não ocorrem de forma minimamente satisfatória, respeitando o ritmo próprio do bebê. Nesses casos, o objeto começa a se fazer presente em um tempo anterior ao das possibilidades de elaboração da percepção da diferença pelo bebê e o não-eu surge como fenômeno imprevisível e dilacerante.

Sublinhamos que o par separação/diferenciação encontra-se intrinsecamente ligado ao par presença/ausência, de forma que o ritmo surge como elemento fundamental na compreensão dos processos de diferenciação. Ciccone (2018) afirma que a ritmicidade organiza a experiência de separação no desenvolvimento do bebê, ajudando a curar a fratura que esta produz. A partir da afirmação de que o ritmo organiza a separação, propusemos a ideia de que um ritmo não gerenciado leva a falhas nos processos de separação/diferenciação.

No campo das automutilações, formulamos a hipótese de que haveria um excesso de descontinuidades vivido no momento primevo de instauração dos processos de diferenciação entre sujeito e objeto, culminando em falhas rítmicas entre o par mãe-bebê. Essas falhas constituem uma dimensão de disritmia precoce, deixando em evidência os desencontros e desarmonias experimentadas pelo bebê em termos de apreensão gradativa do mundo. Devido à falta de sintonia do par, o outro enquanto não-eu teria surgido de forma precoce e/ou abrupta para o bebê, que ainda não tinha elementos para se ver diferenciado.

Essas vivências levam a uma dimensão arcaica da automutilação que denuncia as disritmias que compuseram o par sujeito e objeto primordial. Ecos advindos dos primeiros processos de diferenciação surgem em diferentes momentos da vida, em diferentes situações de perda do outro. Nesses casos, separar-se de uma figura importante na adolescência ou na vida adulta (que pode ser o próprio objeto primordial ou alguém que ocupe esse lugar de importância) pode vir a significar a não existência, como se o eu fosse se perder junto com o outro que parte.

No caso das automutilações, percebemos que o sentimento de continuidade de existência se encontra prejudicado. Para dar conta desta vivência de ameaça de aniquilamento, uma saída radical na automutilação seria buscar uma espécie de contenção, que é alcançada através do ato de ferir o próprio corpo, encontrando alívio temporário em uma atividade de convocação da sensorialidade com o intuito de recuperar a integridade narcísica ameaçada. Se a continuidade de existência é garantida inicialmente pelas trocas rítmicas existentes entre o par 
mãe-bebê, mediadas pela sensorialidade, o sujeito que se automutila recorre a esse efeito de integração que adviria do encontro com o sensorial.

No quarto capítulo, apresentamos a dimensão arcaica das automutilações que se faz presente, especialmente na clínica, demandando do analista uma disponibilidade polifônica complementar ao campo do verbal, permitindo que ele "escute" também elementos que fazem parte de uma escuta pré-verbal e afetiva. Com o intuito de melhor exemplificar esta dimensão arcaica na clínica, apresentamos três fragmentos de casos atendidos pela autora, entrelaçando as discussões do presente trabalho com a prática clínica.

Apresentamos as contribuições de Ciccone $(2011 ; 2012)$ acerca do arcaico nas automutilações. A forma de apreensão do mundo e as marcas deixadas pela nossa experiência enquanto bebês não desaparece nem se transforma completamente com o passar do tempo, na direção da vida adulta. A maneira de se relacionar com o mundo permanece lado a lado com outros modelos de compreensão de si mesmo e dos outros. $\mathrm{O}$ autor também apresenta as automutilações como uma via atual através da qual algumas vivências da ordem do arcaico se apresentariam, em um registro que conjuga, ao mesmo tempo, passado e presente.

Esta forma de compreensão do arcaico coloca em jogo um curto-circuito no tempo, de maneira que formas bastante primitivas de se relacionar com o entorno surgem na superfície de relações agora muito mais complexas. Roussillon (2010b) aponta que, nos momentos iniciais da vida, o bebê não conhece o conceito de tempo linear, de forma que as experiências passadas neste período tendem a ser vividas como eternas e as não experiências como um grande vazio, uma vez que o próprio sentimento de existência só ocorre através das sensações e do contato com o outro. A dimensão arcaica da automutilação nos remete a essa espécie de "tempo além do tempo", no qual as vivências do par mãe-bebê excederam as capacidades de integração egoica, lançando o sujeito em um sentimento de eterno vazio, de não-existência.

Em relação às experiências precoces e a clínica psicanalítica, tomamos como base as contribuições de Ciccone (2012) sobre os aspectos bebê de si, que seriam estas formas de estar no mundo e de se relacionar, construídas em um momento pré-verbal, mas que podem estar presentes em qualquer momento da vida do sujeito. Estes aspectos estariam referidos aos traços de experiências 
arcaicas, guardados sob outras formas de registro sensorial, que adviriam de um momento ainda anterior à aquisição de linguagem e que se fazem presentes no e através do corpo.

Na mesma direção, Roussillon (2004a) apresenta a hipótese de que toda comunicação de um ser humano adulto, ou já dotado de palavras, deve ser considerada em diferentes níveis e modalidades de organização, especialmente um nível pré-verbal e outro pós-verbal, que convivem lado a lado durante toda a vida. Ressaltamos que as dimensões da comunicação pré-verbal não desaparecem, de forma que é possível escutarmos o "bebê" presente no adulto, herança de formas de comunicação pré-verbal conquistadas a partir de experiências precoces e não integradas dos primórdios da vida.

Pensando acerca destas modalidades de comunicação, destacamos a importância de voltar nossos olhares - ouvidos e outros sentidos - para esta singularidade polifônica que se faz presente no campo analítico da automutilação. No presente trabalho, nós apostamos na compreensão dos discursos que levam em conta a sensorialidade e o ritmo; e a forma pela qual o encontro com eles nos apresentam elementos da ordem do arcaico (em suas dimensões primeva e atual). Na clínica da automutilação, estes elementos serão fundamentais na direção de (re)compor o par intersubjetivo, dessa vez formado por analista/paciente.

Destacamos ainda o lugar que ocupam as trocas sensoriais na clínica da automutilação, especialmente em relação ao olhar do analista. Estar aberto para outros elementos que complementam a associatividade verbal e a interpretação aparece nesta clínica como ferramenta essencial de trabalho analítico, abrindo o campo polifônico para a escuta de elementos da ordem do arcaico, advindos das primeiras relações intersubjetivas.

Essa escuta será fundamental no estabelecimento de uma zona de compartilhamento afetivo e sensorial daquilo que se passa com o paciente em seu próprio corpo, conjugando passado e presente, psíquico e somático. Ocupando um lugar de presença objetal diferenciado, estando presente de corpo inteiro, não apenas com ouvidos para as palavras, mas colocando em jogo outras escutas, o analista poderá compor um par intersubjetivo com o paciente, inicialmente se adaptando ao ritmo de segurança do paciente na direção de uma coconstrução rítmica própria ao par analista/paciente. 
A automutilação permite que o sujeito recupere sensações advindas de elementos que são ao mesmo tempo repetitivos, porém novos e também formadores da vida psíquica. Estes elementos sensoriais recuperados e criados pelo ato surgem como plano de fundo através do qual podem surgir novas simbolizações. Esses elementos arcaicos dos primórdios sensoriais não estão perdidos em uma memória que ficou "no passado", formada por acontecimentos que pertencem a uma linha do tempo cronológica, mas fazem-se presentes no atual da vida de todos os sujeitos. Eles estão presentes e se fazem presentes nas formas de se relacionar com os outros sujeitos, ecos de nossas primeiras relações intersubjetivas.

Partindo da importância de acolhermos na clínica da automutilação elementos complementares ao campo do verbal e da associatividade, nos voltamos para a possibilidade de "ouvir" elementos advindos do sensorial, especialmente o olhar do analista. Estas possibilidades polifônicas auxiliam a compor novos encontros intersubjetivos com estes pacientes, na esperança de serem encontros mais harmônicos e em direção a uma sintonia mais afinada para ambos. 


\section{6 \\ Referências bibliográficas}

Aguiar, H. C. (2016). Quando a partida antecede a chegada: singularidades do óbito fetal. (Dissertação de Mestrado). Pontifícia Universidade Católica do Rio de Janeiro, Rio de Janeiro, RJ, Brasil.

American Psychiatric Association. (2014). Manual diagnóstico e estatístico de transtornos mentais: DSM-5. Porto Alegre: Artmed.

André, J. (2008). O acontecimento e a temporalidade: o après-coup no tratamento. Revista Psicanálise e Cultura, 31(47), 139-167. Recuperado a partir de http://pepsic.bvsalud.org/pdf/ide/v31n47/v31n47a25.pdf.

Anzieu, D. (2000). O Eu-pele (2 ${ }^{\mathrm{a}}$ ed.). São Paulo: Casa do Psicólogo. (Originalmente publicado em 1985).

Anzieu, D. (2007). La peau: du plaisir à la pensée. In C. Chabert (Org.), Psychanalyse des limites (pp. 15-25). Paris: Dunod. (Originalmente publicado em 1974).

Aragão, R. O. (2016). Presença/ausência materna e os processos de subjetivação. (Tese de Doutorado). Pontifícia Universidade Católica do Rio de Janeiro, Rio de Janeiro, RJ, Brasil.

Aragão, R. O. (2018). A sensorialidade e os processos de subjetivação. Primórdios, 5(5), 13-23.

Aragão, R. O. \& Zornig, S. (2018). Apresentação. In R. O. Aragão \& S. Zornig (Orgs.), Continuidade e descontinuidade no processo de subjetivação do bebê (pp. 7-12). São Paulo: Escuta.

Araujo, L. (2005). Tatuagem, piercing e outras mensagens do corpo. São Paulo: Cosac Naify.

Barrault, C. (2005). L'adolescence à fleur de peau: se couper pour exister. (Tese de doutorado). Université Henri Poincaré - Nancy I, Nancy, França.

Bick, E. (1968). The experience of the skin in early object relations. International Journal of Psychoanalysis, 49, 484-486.

Birraux, A. (2013). L'adolescent face à son corps. Paris: Albin Michel. (Originalmente publicado em 1994).

Botella, C. \& Botella, S. (2002). Irrepresentável: mais além da representação. Porto

Alegre: Criação Humana. 
Braconnier, A. \& Golse, B. (2008). Bébés-ados: crises et chuchotements. Toulouse: Érès.

Brassine, C. \& Lefebvre, A. (2007). L'auto-agression itérative de l'enveloppe cutanée: une défense paradoxale. Psychologie clinique et projective, 1(13), 313346. Recuperado a partir de http://www.cairn.info/revue-psychologie-clinique-etprojective-2007-1-page-313.htm.

Brun, A. (2014a). Introduction. In A. Brun \& R. Roussillon (Orgs.), Formes primaires de symbolisation (pp. 1-10). Paris: Dunod.

Brun, A. (2014b). De la sensori-motricité à la symbolisation dans les médiations thérapeutiques pour enfants psychotiques. In A. Brun \& R. Roussillon (Orgs.), Formes primaires de symbolisation (pp. 11-33). Paris: Dunod.

Brun, A. (2017). Archaïque, sensorialité et processus créateur. In J. Bouhsira \& S. Missonnier (Orgs.), L'originaire et l'archaïque (pp. 165-179). Paris: PUF.

Burešová, I. (2016). Self-harm classification system development: theoretical study. Review of Social Sciences, 1(4), 13-20. Recuperado a partir de https://pdfs.semanticscholar.org/ea55/f4efd9331d4f51a9bd196ac035fb39fd9c6c.p df.

Câmara, L. \& Canavêz, F. (2019). Contribuições de Sándor Ferenczi para o fenômeno da autolesão. No prelo.

Cardoso, M. R. (2001). Adolescência e violência: uma questão de "fronteiras"? In M. R. Cardoso (Org.), Adolescência: reflexões psicanalíticas (pp. 41-53). Rio de Janeiro: Nau.

Cardoso, M. R. (Org.). (2006). Adolescentes. São Paulo: Escuta.

Cardoso, M. R. (2014). Dependência e adolescência: a recusa da diferença. Ágora, 17, 63-74.

Chouvier, B. (2008). L'acte symbolique: donner um corps au fantasme. In B. Chouvier \& R. Roussillon (Orgs.), Corps, acte et symbolisation (pp. 7-20). Bruxelles: De Boeck.

Ciccone, A. (2008). L'archaïque et l'infantile. Spirale, 1(45), 133-147. Recuperado a partir de http://www.cairn.info/revue-spirale-2008-1-page-133.htm.

Ciccone, A. (2011). La psychanalyse à l'épreuve du bébé. Paris: Dunod.

Ciccone, A. (2012). La parte bébé du soi. In A. Ciccone (Org.), La parte bébé du soi: approche clinique (pp. 1-22). Paris: Dunod.

Ciccone, A. (2018). A ritmicidade nas experiências do bebê, sua segurança interna e sua abertura para o mundo. In R. O. Aragão \& S. Zornig (Orgs), Continuidade e 
descontinuidade no processo de subjetivação do bebê (pp. 15-28). São Paulo: Escuta.

Cidade, N. \& Zornig, S. (2016). Trauma, temporalidade e inscrição psíquica. Cadernos de Psicanálise - CPRJ, 38(35), 29-47.

Cidade, N. \& Zornig, S. (2019). Polifonias em análise: os processos de simbolização primária. Psicologia USP, 30, e180178. Recuperado a partir de https://doi.org/10.1590/0103-6564e180178.

Corcos, M. (2013). La terreur d'exister. Paris: Dunod. (Originalmente publicado em 2009).

Corcos, M. \& Richard, B. (2006). L'emotion mutilée: approche psychanalytique des automutilations à l'adolescence. La psychiatrie de l'enfant, 49(2),459-476. Recuperado a partir de https://www.cairn.info/revue-la-psychiatrie-de-1-enfant2006-2-page-459.htm

Cupa, D. (2006). Une topologie de la sensualité: le moi-peau. Revue française de psychosomatique, 1(29), 83-100. Recuperado a partir de https://www.cairn.info/revue-francaise-de-psychosomatique-2006-1-page-83.htm.

Dalgalarrondo, P. (2008). Psicopatologia e semiologia dos transtornos mentais. Porto Alegre: Artmed.

Dargent, F. (2010). Corps scarifié, adolescence marquée. Revue française de psychosomatique, 2(38), 131-143. Recuperado a partir de https://www.cairn.info/revue-francaise-de-psychosomatique-2010-2-page131.htm.

Dargent, F. \& Matha, C. (2011). Blessures de l'adolescence. Paris: PUF.

De Luca, M.; Bonnichon, D. \& Marty, F. (2012). Les scarifications à l'adolescence: un équivalent suicidaire? La psychiatrie de l'enfant, 55(2), 637678.

Demantova, A. G. (2017). Escarificações na adolescência: corpo atacado, corpo marcado. (Dissertação de Mestrado). Universidade Federal do Rio de Janeiro, Rio de Janeiro, RJ, Brasil.

Douville, O. (2004). L'automutilation, mise en perspectives de quelques questions. Champ Psy, 4(36), 7-24. Recuperado a partir de https://www.cairn.info/revue-champ-psychosomatique-2004-4.htm.

Favazza, A. (2011). Bodies under siege: self-mutilation, nonsuicidal self-injury, and body modification in culture and psychiatry ( $3^{\mathrm{a}}$ ed.). Baltimore: John Hopkins University Press. (Originalmente publicado em 1987).

Feldman, M. D. (1988). The challenge of self-mutilation: a review. Comprehensive Psychiatry, 29, 252-69. 
Ferenczi, S. (2011a). Reflexões psicanalíticas sobre os tiques. In S. Ferenczi, Psicanálise III (pp. 77-104). São Paulo: Martins Fontes. (Originalmente publicado em 1921).

Ferenczi, S. (2011b). Thalassa: ensaio sobre a teoria da genitalidade. In S. Ferenczi, Psicanálise III (pp. 255-326). São Paulo: Martins Fontes. (Originalmente publicado em 1924).

Ferreira, J. C. (2014). Mensagens sobre escarificações na Internet: um estudo psicanalítico. (Dissertação de Mestrado). Universidade Estadual de Maringá, Paraná, Brasil.

Firestone R. W. \& Seiden R. H. (1990). Suicide and the continuum of selfdestructive behavior. Journal of American College Health, 38, 207-213.

Fontes, I. (2001). Transferência - uma regressão alucinatória. Revista Latinoamericana de Psicopatologia Fundamental, 4(4), 18-28.

Fontes, I. (2010). Psicanálise do sensível: fundamentos e clínica. São Paulo: Ideias \& Letras.

Freud, S. (1996a). Carta 52. In S. Freud, Edição standard brasileira das obras psicológicas completas de Sigmund Freud (J. Salomão, trad., Vol. 1, pp. 281287). Rio de Janeiro: Imago. (Originalmente escrito em 1896 e publicado em 1950).

Freud, S. (1996b). Lembranças encobridoras. In S. Freud, Edição standard brasileira das obras psicológicas completas de Sigmund Freud (J. Salomão, trad., Vol. 3, pp. 285-304). Rio de Janeiro: Imago. (Originalmente publicado em 1899).

Freud, S. (1996c). Sobre a psicopatologia da vida cotidiana. In S. Freud, Edição standard brasileira das obras psicológicas completas de Sigmund Freud (J. Salomão, trad., Vol. 6, pp. 12-272). Rio de Janeiro: Imago. (Originalmente publicado em 1901).

Freud, S. (1996d). Três ensaios sobre a teoria da sexualidade. In S. Freud, Edição standard brasileira das obras psicológicas completas de Sigmund Freud (J. Salomão, trad., Vol. 7, pp. 117-231). Rio de Janeiro: Imago. (Originalmente publicado em 1905).

Freud, S. (1996e). Sobre o narcisismo: uma introdução. In S. Freud, Edição standard brasileira das obras psicológicas completas de Sigmund Freud (J. Salomão, trad., Vol. 14, pp. 77-108). Rio de Janeiro: Imago. (Originalmente publicado em 1914).

Freud, S. (1996f). Os instintos e suas vicissitudes. In S. Freud, Edição standard brasileira das obras psicológicas completas de Sigmund Freud (J. Salomão, trad., Vol. 14, pp. 117-144). Rio de Janeiro: Imago. (Originalmente publicado em 1915). 
Freud, S. (1996g). Além do princípio do prazer. In S. Freud, Edição standard brasileira das obras psicológicas completas de Sigmund Freud (J. Salomão, trad., Vol. 18, pp. 12-75). Rio de Janeiro: Imago. (Originalmente publicado em 1920).

Freud, S. (1996h). O Ego e o Id. In S. Freud, Edição standard brasileira das obras psicológicas completas de Sigmund Freud (J. Salomão, trad., Vol. 19, pp. 15-80). Rio de Janeiro: Imago. (Originalmente publicado em 1923).

Freud, S. (1996i). Uma nota sobre o bloco mágico. In S. Freud, Edição standard brasileira das obras psicológicas completas de Sigmund Freud (J. Salomão, trad., Vol. 19, pp. 253-259). Rio de Janeiro: Imago. (Originalmente escrito em 1924 e publicado em 1925).

Freud, S. (1996j). Inibições, sintomas e ansiedade. In S. Freud, Edição standard brasileira das obras psicológicas completas de Sigmund Freud (J. Salomão, trad., Vol. 20, pp. 81-171). Rio de Janeiro: Imago. (Originalmente escrito em 1925 e publicado em 1926).

Freud, S. (1996k). Moisés e o monoteísmo. In S. Freud, Edição standard brasileira das obras psicológicas completas de Sigmund Freud (J. Salomão, trad., Vol. 23, pp. 15-150). Rio de Janeiro: Imago. (Originalmente escrito entre 1934 e 1938 e publicado em 1939).

Freud, S. (19961). Achados, ideias, problemas - Breves escritos. In S. Freud, Edição standard brasileira das obras psicológicas completas de Sigmund Freud (J. Salomão, trad., Vol. 23, pp. 317-318). Rio de Janeiro: Imago. (Originalmente escrito em 1938 e publicado em 1941).

Garel, P. (2008). L'automutilation superficielle à l'adolescence: le corps dans tous ses états. Cahiers critiques de thérapie familiale et de pratiques de réseaux, 1(40), 227-235. Recuperado a partir de http://www.cairn.info/revue-cahiers-critiques-detherapie-familiale-2008-1-page-227.htm.

Gicquel, L. \& Corcos, M. (2011). Les automutilations à l'adolescence. Paris: Dunod.

Giusti, J. S. (2013). Automutilação: características clínicas e comparação com pacientes com transtorno obsessivo-compulsivo. (Tese de doutorado). Universidade de São Paulo, São Paulo, SP, Brasil.

Golse, B. \& Roussillon, R. (2010). La naissance de l'objet. Paris: PUF.

Golse, B. \& Desjardins, V. (2005). Corpo, formas, movimentos e ritmo como precursores da emergência da intersubjetividade e da palavra no bebê (uma reflexão sobre os inícios da linguagem verbal). Revista Latinoamericana de Psicopatologia Fundamental, 8(1), 14-29. 
Golse, B. (2001). De la différenciation à la séparation: it's a long way to go! Revue française de psychanalyse, 2(65), 369-380. Recuperado a partir de https://www.cairn.info/revue-francaise-de-psychanalyse-2001-2-page-369.htm.

Golse, B. (2006). L'être-bébé. Paris: PUF.

Golse, B. (2014). De l'intersubjectivité à la subjectivation: un exemple de passage de l'interpersonnel à l'intrapsychique. Enfances \& Psy, 1(62), 29-38. Recuperado a partir de https://www.cairn.info/revue-enfances-et-psy-2014-1-page-29.htm.

Golse, B. (2018). Préface. In V. Guerra. Rythme et intersubjectivité chez le bébé (pp. 7-12). Toulouse: Érès.

Gratz, K. (2003). Risk factors for and functions of Deliberate Self-Harm: an empirical and conceptual review. Clinical psychology: science and practice, 10, 192-205.

Green, A. (1990). Après coup, l'archaïque. In A. Green, La folie privée (pp. 259291). Paris: Gallimard. (Originalmente publicado em 1982).

Guerra, V. (2018a). Rythme et intersubjectivité chez le bébé. Toulouse: Érès.

Guerra, V. (2018b). Formas de (de)subjetivação infantil em tempos de aceleração: os transtornos da subjetivação arcaica. In R. O. Aragão \& S. Zornig (Orgs.), Continuidade e descontinuidade no processo de subjetivação do bebê (pp. 165191). São Paulo: Escuta.

Haag, G. (1986). Adhésivité, identité adhésive, identification adhésive. GRUPPO, 2, 110-116.

Haag, G. (1990). Approche psychanalytique de l'autisme et des psychose de l'enfant. In P. Mazet \& S. Lebovici (Orgs.), Autisme et psychoses de l'enfant (pp. 143-155). Paris: PUF.

Haag, G. (2004). Sexualité orale et moi corporel. Topique, 2(87), 23-45. Recuperado a partir de http://www.cairn.info/revue-topique-2004-2-page-23.htm.

Haag, G. (2006). Clivages dans les premières organisations du moi: sensorialités, organisation perceptive et image du corps. Le Carnet PSY, 8(112), 40-42. Recuperado a partir de http://www.cairn.info/revue-le-carnet-psy-2006-8-page40.htm.

Haag, G. (2018). Le moi corporel: autisme et développement. Paris: PUF.

Konicheckis, A. (1999). Identité sensorielle chez le bébé et chez l'adolescent. Adolescence, 139-149. Recuperado a partir de https://www.cairn.info/troubles-dela-personnalite-troubles-des-conduite--9782825707210-page-139.htm. 
Konicheckis, A. (2002). Des sens aux sens, sensorialité et signification. In M. Boubli \& A. Konicheckis (Orgs.), Clinique psychanalytique de la sensorialité (pp. 125-155). Paris: Dunod.

Konicheckis, A. (2008). De génération en génération: la subjectivation et les liens précoces. Paris: PUF.

Konicheckis, A. (2016). Les sensations entre plasticité, ombre et arrière-plan.

Revue française de psychanalyse, 4(80), 1012-1023. Recuperado a partir de https://www.cairn.info/revue-francaise-de-psychanalyse-2016-4-page-1012.htm.

Konicheckis, A. (2018). Subjetivação e sensorialidade: os embriões do sentido. In R. O. Aragão \& S. Zornig (Orgs), Continuidade e descontinuidade no processo de subjetivação do bebê (pp. 75-94). São Paulo: Escuta.

Lacombe, P. (1959). Du rôle de la peau dans l'attachement mère-enfant. Revue française de psychanalyse, 1(23), 83-102.

Laplanche, J. \& Pontalis, J.-B. (1970). Vocabulário da psicanálise (5ª ed.). São Paulo: Martins Fontes. (Originalmente publicado em 1967).

Le Breton, D. (2010). Se reconstruire par la peau: marques corporelles et processus initiatique. Revue française de psychosomatique, 2(38), 85-95. Recuperado a partir de http://www.cairn.info/revue-francaise-depsychosomatique-2010-2-page-85.htm.

Lorthiois, M. M. (1909). De l'automutilation: mutilations et suicides étranges. Paris: Vigot Frères.

Maldonado, G. (2012). Neurose traumática: fundamentos e destinos. Curitiba: Juruá.

Mano, B. C. (2013). Clínica do continente. São Paulo: Casa do Psicólogo.

Marty, F. (2007). À propos de la résistance narcissique à l'investissement de l'objet de l'adolescence. In A. Braconnier (Org.), L'adolescence aujourd'hui (pp. 43-49). Toulouse: Érès.

Marty, F. (2010). Adolescence et émotion, une affaire de corps. Enfances \& Psy, 4(49), 40-52. Recuperado a partir de https://www.cairn.info/revue-enfances-etpsy-2010-4-page-40.htm.

Matha, C. (2010). De l'inscription à la representation: les scarifications à l'adolescence comme recherche de symbolisation? La psychiatrie de l'enfant, 53(1), 255-283. Recuperado a partir de https://www.cairn.info/revue-lapsychiatrie-de-1-enfant-2010-1-page-255.htm.

Mayer, H. (2001). Passagem ao ato, clínica psicanalítica e contemporaneidade. In M. R. Cardoso (Org.), Adolescência: reflexões psicanalíticas (pp. 81-101). Rio de Janeiro: Nau. 
McDougall, J. (1987). Um corpo para dois. In J. McDougall, Conferências brasileiras. Rio de Janeiro: Xenon.

Menninger, K. (1970). Eros e tânatos: o homem contra si próprio. São Paulo: Ibrasa. (Originalmente publicado em 1938).

Moro, M. R. (2008). Narrativité et traumatisme. In A. Braconnier \& B. Golse (Orgs.), Bébés-ados: crises et chuchotements (pp. 187-199). Toulouse: Érès.

Muehlenkamp, J. J. (2005). Self-injurious behavior as a separate clinical syndrome. American Journal of Orthopsychiatry, 75(2), 324-333.

Narjisse, K. (2014). Les automutilations en psychiatrie: étude descriptive de 12 mois. (Monografia apresentada para obtenção de diploma em Psiquiatria). Université Sidi Mohammed Ben Abdallah, Fez, Marrocos.

Nock, M. K. (2010). Self-Injury. Annual Review of Clinical Psychology, 6, 339363. Recuperado a partir de http://nocklab.fas.harvard.edu/files/nocklab/files/nock_2010__ selfinjury_arcp.pdf.

McDougall, J. (1987). Um corpo para dois. In J. McDougall, Conferências brasileiras (pp. 19-52). Rio de Janeiro: Xenon.

Organização Mundial de Saúde. (2011). Classificação de transtornos mentais e de comportamento da CID-10: descrições clínicas e diretrizes diagnósticas. Porto Alegre: Artes Médicas. (Originalmente publicado em 1993).

Pattison, E. M. \& Kahan, J. (1983). The deliberate self-harm syndrome. American Journal of Psychiatry, 140(7), 867-872.

Pao, P-N. (1969). The syndrome of delicate self-cutting. British Journal of Medical Psychology, 42, 195-206.

Perret-Catipovic, M. (2005). Blessures auto-infligées à l'adolescence: un survol de la littérature. Adolescence, 2(52), 447-456. Recuperado a partir de https://www.cairn.info/revue-adolescence-2005-2-page-447.htm.

Pommereau, X. (2006a). Les marques cutanées à l'adolescence. Le Journal des Psychologues, 10(243), 71-75. Recuperado a partir de http://www.cairn.info/revue-le-journal-des-psychologues-2006-10-page-71.htm.

Pommereau, X. (2006b). Les violences cutanées auto-infligées à l'adolescence. Enfances \& Psy, 3(32), 58-71. Recuperado a partir de https://www.cairn.info/revue-enfances-et-psy-2006-3-page-58.htm.

Pommereau, X.; Brun, M. \& Moutte, J-P. (2009). L'adolescence scarifiée. Paris: L'Harmattan. 
Prat, R. (2007). La préhistoire de la vie psychique: son devenir et ses traces dans l'opéra de la rencontre et le processus thérapeutique. Revue française de psychanalyse, 71(1), 97-114. Recuperado a partir de https://www.cairn.info/revuefrancaise-de-psychanalyse-2007-1-page-97.htm.

Prat, R. (2010). Histoire de peau: à fleur de peau, peau de chagrin, peau de vache, tenir à sa peau, avoir dans la peau, être dans la peau, faire la peau, faire peau neuve... Revue française de psychanalyse, 74(5), 1635-1640. Recuperado a partir de http://www.cairn.info/revue-francaise-de-psychanalyse-2010-5-page-1635.htm.

Quinodoz, J-M. (2014). La solitude apprivoisée: l'angoisse de séparation en psychanlyse ( $5^{\mathrm{a}}$ ed.). Paris: PUF. (Originalmente publicado em 1991).

Richard, B. (2005). Les comportements de scarification chez l'adolescent. Neuropsychiatrie de l'enfance et de l'adolescence, 53, 134-141.

Rosenthal, R. J.; Rinzler, C.; Wallsh, R. \& Klausner, E. (1972). Wrist-cutting syndrome: the meaning of a gesture. American Journal of Psychiatry, 128(11), $1363-1368$.

Ross, R. R. \& McKay, H. B. (1979). Self-mutilation. Lexington, MA: Lexington Books.

Roussillon, R. (1999). Agonie, clivage et symbolisation. Paris: PUF.

Roussillon, R. (2004a). À l'écoute du bébé dans l'adulte. Exploration en psychanalyse. Recuperado a partir de https://reneroussillon.files.wordpress.com/2014/07/avignon-204.pdf.

Roussillon, R. (2004b). La dépendance primitive et l'homosexualité primaire « en double ». Revue française de psychanalyse, 68(2), 421-439.

Roussillon, R. (2006a). Du jeu dans la mémoire. In B. Chouvier \& R. Roussillon (Orgs.), La temporalité psychique: psychanalyse, mémoire et pathologies du temps (pp. 7-20). Paris: Dunod.

Roussillon, R. (2006b). Paradoxos e situações limites da psicanálise. São Leopoldo: Unisinos.

Roussillon, R. (2007). Le Moi-peau et la réflexivité. In C. Chabert; D. Cupa ; R. Kaës \& R. Roussillon (Orgs.), Didier Anzieu: le Moi-peau et la psychanalyse des limites (pp. 89-102). Toulouse: Érès. (Originalmente publicado em 2007).

Roussillon, R. (2008). Corps et actes messagers. In B. Chouvier \& R. Roussillon (Orgs.), Corps, acte et symbolisation (pp. 23-37). Bruxelles: De Boeck.

Roussillon, R. (2010a). La perte du potentiel. perdre ce qui n'a pas eu lieu. In A. Braconnier \& B. Golse (Orgs.), Dépression du bébé, dépression de l'adolescent (pp. 251-264). Toulouse: Érès. 
Roussillon, R. (2010b). La psychanalyse à l'écoute de l'histoire archaïque et la communication non verbale. In B. Cramer, S. Eliez \& B. Solca (Orgs.), Des psychanalystes en pédopsychiatrie (pp. 96-117). Paris: PUF.

Roussillon, R. (2011). Primitive agony and symbolization. Londres: Karnac.

Roussillon, R. (2012a). As condições da exploração psicanalítica das problemáticas narcísico-identitárias. ALTER - Revista de estudos psicanalíticos, 30(1), 7-32. Recuperado a partir de https://reneroussillon.files.wordpress.com/2014/08/rennc3a9ede-roussillon-artigoalter.pdf.

Roussillon, R. (2012b). Pertinence du concept de symbolisation primaire. Exploration en psychanalyse. Recuperado a partir de https://reneroussillon.files.wordpress.com/ 2014/07/symb-primaire-13-c.pdf

Roussillon, R. (2013). La séparation et la dialectique présence/abscence. In C. Chabert (Org.), Les séparations (pp. 213-230). Toulouse: Érès.

Roussillon, R. (2015). Un processus sans sujet. Le Carnet PSY, Paris, (4)189, 3135. Recuperado a partir de http://www.cairn.info/article.php?ID_ARTICLE= LCP_189_0031

Savietto, B. (2007). Passagem ao ato e adolescência contemporânea: pais "desmapeados", filhos desamparados. Revista Latinoamericana de Psicopatologia Fundamental, 10(3), 438-453, 2007. Recuperado a partir de http://www.fundamentalpsychopathology.org/uploads/files/revistas/volume10/n3/ passagem_ao_ato_e_adolescencia_contemporanea_pais_desmapeados_filhos_des amparados.pdf.

Scaramozzino, S. (2004). Pour une approche psychiatrique de l'automutilation: implications nosographiques. Champ Psy, 4(36), 25-38, 2004. Recuperado a partir de https://www.cairn.info/revue-champ-psychosomatique-2004-4.htm.

Sinclair, J. \& Green, J. (2005). Understanding resolution of deliberate self harm: qualitative interview study of patients' experiences. $B M J, 330,1112,1-5$. Recuperado a partir de https://www.bmj.com/content/330/7500/1112.short.

Suyemoto, K. L. (1998). The functions of self-mutilation. Clinical Psychology Review, 18(5), 531-554. Recuperado a partir de http://www.brown.uk.com/selfinjury/ suyemoto2.pdf.

Suyemoto, K. L. \& Macdonald, M. L. (1995). Self-cutting in female adolescents. Psychotherapy: Theory, Research, Practice, Training, 32(1), 162-171.

Tustin, F. (1977). Autisme et psychose de l'enfant. Paris: Éditions du Seuil.

Tustin, F. (1984). Estados autísticos em crianças. Rio de Janeiro: Imago. 
Tustin, F. (1990). Barreiras autistas em pacientes neuróticos. Porto Alegre: Artes Médicas.

Walsh, B. W. \& Rosen P. (1988). Self-mutilations: theory, research and treatment. New York: Guilford Press.

Winnicott, D. W. (1975a). Objetos transicionais e fenômenos transicionais. In D. W. Winnicott, $O$ brincar e a realidade (pp. 13-44). Rio de Janeiro: Imago. (Originalmente publicado em 1953).

Winnicott, D. W. (1975b). A localização da experiência cultural. In D. W. Winnicott, $O$ brincar e a realidade (pp. 133-143). Rio de Janeiro: Imago. (Originalmente publicado em 1967).

Winnicott, D. W. (1975c). O papel de espelho da mãe e da família no desenvolvimento infantil. In D. W. Winnicott, O brincar e a realidade (pp. 153162). Rio de Janeiro: Imago. (Originalmente publicado em 1967).

Winnicott, D. W. (1983). Os doentes mentais na prática clínica. In D. W. Winnicott, $O$ ambiente e os processos de maturação (pp. 196-206). Rio de Janeiro: Imago. (Originalmente publicado em 1963).

Winnicott, D. W. (1994). O medo do colapso. In D. W. Winnicott, Explorações psicanalíticas ( $\mathrm{a}^{\mathrm{a}}$ ed., pp. 70-76). Porto Alegre: Artmed. (Originalmente publicado em 1974). 